\author{
GÖTTINGER ZENTRUM \\ FÜR BIODIVERSITÄTSFORSCHUNG UND ÖKOLOGIE \\ - Göttingen Centre for Biodiversity And Ecology -
}

\title{
The effects of climate change on fine root dynamics in a Norway spruce forest
}

\author{
Dissertation zur Erlangung des Doktorgrades der \\ Mathematisch-Naturwissenschaftlichen Fakultäten der \\ Georg-August-Universität Göttingen
}

vorgelegt von

Dirk Gaul

aus

Mainz

Göttingen, Juli, 2008 
Referentin/Referent: Prof. Dr. Christoph Leuschner

Korreferentin/Korreferent: Prof. Dr. Dirk Hölscher

Tag der mündlichen Prüfung: 


\section{Summary}

Because of methodological restrictions, exact quantifications of the carbon sink strength of fine root systems are not available for mature forests. However, for assessing the effects of climate change on root-derived carbon fluxes to the soil, this knowledge is urgently needed. In my thesis, I applied sequential soil coring and minirhizotron observations to investigate the impacts of experimental summer drought and winter frost on fine root dynamics of Norway spruce by replicated throughfall exclusion and snow removal experiments in Southeast Germany. In addition, I estimated fine root longevity distribution with root diameter, root $\mathrm{C} / \mathrm{N}$ ratio and soil depth under natural conditions using sequential soil coring, minirhizotrons and radiocarbon analyses as three independent methods. I tested the hypotheses that (i) soil drought and soil frost increase fine root mortality leading to a higher input of root-born organic matter into the soil and that (ii) drought- and frost-induced fine root mortality is compensated by higher rates of fine root production. Excluding throughfall for a period of six weeks reduced average soil moisture from 20 to $12 \mathrm{vol}$. \% in the upper mineral soil, while snow removal induced soil frost with temperatures down to $-5.5{ }^{\circ} \mathrm{C}$ in the organic layer. Sequential coring showed that soil drought and frost increased fine root mortality in the organic layer of the studied spruce stand by 61 and $29 \%$, respectively. However, enhanced fine root production compensated for the root losses caused by water shortage and low temperatures. Minirhizotron observations revealed that drought stress was mainly restricted to the organic layer, while frost stress was similar in the organic layer and the upper $25 \mathrm{~cm}$ of the mineral soil. We calculated that experimental soil drought and frost led to additional carbon inputs to the soil of about 28 and $47 \mathrm{~g} \mathrm{~m}^{-2}$. Under natural conditions, the carbon age of fine roots increased with depth from 5 years in the organic layer to 13 years in $40-60 \mathrm{~cm}$ mineral soil. Similarly, the $\mathrm{C} / \mathrm{N}$ ratios of fine root samples were lowest in the organic layer and increased with depth. Roots $>0.5 \mathrm{~mm}$ in diameter tended to live longer than roots $<0.5 \mathrm{~mm}$ in diameter. Furthermore, the results on mean root longevity were strongly influenced by the method of investigation. Radiocarbon analyses yielded with 5.4 years much higher estimates than sequential coring $(0.9$ years) and minirhizotron observations ( 0.7 years). I conclude that even periods of relatively mild drought and frost have considerable potential to increase fine root mortality and the associated input of root-derived carbon to the soil organic matter pool in temperate Norway spruce forests. In addition, I propose that sequential coring and minirhizotron observations are likely to underestimate fine root longevity, while radiocarbon analyses may lead to overestimations. 


\section{Zusammenfassung}

Feinwurzeln gelten als eine der bedeutendsten Senken im Kohlenstoffhaushalt von Bäumen. Eine genaue Quantifizierung der Bedeutung von Feinwurzelsystemen für den Kohlenstoffkreislauf in Wäldern ist jedoch aufgrund methodischer Schwierigkeiten bislang nicht möglich. In der vorliegenden Dissertation wurden sequentielle Bohrstockbeprobung und Minirhizotrone angewandt um die Auswirkungen von experimenteller Sommertrockenheit und Winterfrost auf die Feinwurzeldynamik von Picea abies im Fichtelgebirge zu untersuchen. Zusätzlich wurde die Lebensdauer von Feinwurzeln in Abhängigkeit von Durchmesser, C/N-Verhältnis und Bodentiefe unter natürlichen Bedingungen durch sequentielle Bohrstockbeprobung, Minirhizotron- und Radiocarbountersuchungen ermittelt. Es wurden die Hypothesen untersucht, dass (i) Austrocknung und Frost die Feinwurzelmortalität erhöhen und dadurch den Eintrag von organischem Material in die Rhizosphäre vergrößern und dass (ii) der trockenheitsbeziehungsweise frostbedingte Feinwurzelverlust $\mathrm{zu}$ einem kompensatorischen Feinwurzelwachstum nach Wiederbefeuchtung beziehungsweise Auftauen führt. Der Ausschluss von Regenwasser über eine Zeit von 6 Wochen verringerte die Bodenfeuchte im oberen Mineralboden von 20 auf 12 Vol. \% während das Räumen von Schnee zu Bodenfrost mit Temperaturen von bis zu $-5.5^{\circ} \mathrm{C}$ in der organischen Auflage führte. Die Ergebnisse der sequentiellen Bohrstockbeprobung zeigten, dass Austrocknung und Frost die Feinwurzelmortalität in der organischen Auflage um 61 beziehungsweise $29 \%$ erhöhten. Der trockenheits- beziehungsweise frostbedingte Feinwurzelverlust wurde jedoch durch erhöhte Feinwurzelproduktion ausgeglichen. Die Ergebnisse der Minirhizotronuntersuchungen deuten darauf hin, dass der Ausschluss von Regenwasser lediglich die Feinwurzeldynamik in der Auflage beeinflusste, während das Schnee räumen zusätzlich Mortalität und Produktion in den oberen $25 \mathrm{~cm}$ des Mineralbodens erhöhte. Es wurde errechnet, dass Austrocknung und Frost den Kohlenstoffeintrag in den Boden um 28 beziehungsweise $47 \mathrm{~g} \mathrm{~m}^{-2}$ erhöhten. Unter natürlichen Bedingungen waren Kohlenstoffalter und $\mathrm{C} / \mathrm{N}-$ Verhältnis von Feinwurzeln am geringsten in der organischen Auflage und stiegen mit zunehmender Tiefe an. Feinwurzeln $>0.5 \mathrm{~mm}$ Durchmesser lebten länger als Feinwurzeln $<0.5 \mathrm{~mm}$. Außerdem wurden die Ergebnisse der durchschnittlichen Lebensdauer stark von der gewählten Untersuchungsmethode beeinflusst. Die Werte der Radiocarbonanalysen deuteten darauf hin, dass Feinwurzeln im untersuchten Fichtenbestand länger als 5 Jahre leben, während sequentielle Bohrstockbeprobung und Minirhizotronuntersuchungen zu deutlich kürzere Lebensdauern (< 1 Jahr) führten. 


\section{Table of contents}

\section{CHAPTER 1}

General introduction

\section{CHAPTER 2}

Effects of experimental drought on the fine root system of

mature Norway spruce

\section{CHAPTER 3}

Effects of experimental soil frost on the fine root system of mature Norway spruce

\section{CHAPTER 4}

Estimating fine root longevity in a temperate Norway spruce forest using three independent methods

\section{CHAPTER 5}

Synthesis 

Chapter 1

General introduction 


\section{Climate change and its impacts on forest ecosystems}

Historic records prove that there has often been considerable variation in the earths' climate (O'Brian et al. 1995; Stager et al. 1997). However, severe changes similar to those having occurred over the past century exceeded the natural climatic variability by far (Free and Robock 1999; Levitus et al. 2001). Processes like the melting of glaciers, the rising of sea levels and the reduction of snow cover in many polar regions have never been observed to take place as fast as over the past 50 years (Haeberli and Beniston 1998; IPCC 2007). On a global scale, temperature has risen on average by approximately $0.7^{\circ} \mathrm{C}$ during the last century (IPCC 2007).

The reasons for present climate change have been discussed for decades. Nowadays, there is convincing evidence that global warming, as it has occurred during the past 50 years, is mainly caused by human activities (IPCC 2007). The emission of greenhouse gases and aerosols combined with the destruction of forests are considered as the most important anthropogenic impacts (Crowley 2000). While exact predictions of future climate are uncertain, major computer models predict an average temperature increase between 1.8 and $4.0{ }^{\circ} \mathrm{C}$ for the next century (IPCC 2007). Even if the emissions of greenhouse gases are kept constant at year 2000 levels, global warming is expected to continue over the next decades (IPCC 2007). As a consequence of the ongoing temperature increase, the global hydrological cycle is also expected to experience major changes. Meteorologists commonly predict increases in winter temperatures and stronger and more frequent summer droughts for many regions of Central Europe (Hulme and Sheard 1999; Johns et al. 2001; Christensen and Christensen 2003; Rowell and Jones 2006). However, global warming in the frame of climate change might also produce some rather unexpected effects. In that context, decreasing snow cover in winter may result in stronger soil frost at higher latitudes and in mountainous regions even though average winter air temperatures are increasing (Cooley 1990).

By fixing large amounts of carbon from the atmosphere through photosynthesis, trees have considerable potential to mitigate the effects of climate change (Bonan 2008). On a global scale, forest ecosystems are estimated to contain about $80 \%$ of the aboveground and $40 \%$ of belowground terrestrial carbon (Dixon et al. 1994). However, climatic changes are expected to alter forest productivity and species distribution in future. Rising levels of $\mathrm{CO}_{2}$ in the atmosphere, increased temperatures and changing precipitation regimes are considered as the most relevant factors affecting forests and their potential to sequester carbon from the atmosphere (Pastor and Post 1988; Mooney et al. 1991). 
There is evidence that plants can grow faster and larger under conditions of elevated $\mathrm{CO}_{2}$ (Curtis and Wang 1998; Norby et al. 1999). Norby et al. (2005) estimated that the net primary production in forests may increase by $23 \%$, as atmospheric $\mathrm{CO}_{2}$ is expected to increase from 375 to $550 \mathrm{ppm}$ over the next decades. However, no response or even a reduction in forest productivity under elevated $\mathrm{CO}_{2}$ was predicted for forests with inadequate water and nutrient supply (Pastor and Post 1988; Luo et al. 2004). Enhanced plant productivity due to rising $\mathrm{CO}_{2}$ levels is expected to become particularly relevant in tropical and temperate dry forests (Melillo et al. 1993). By contrast, in northern and moist temperate forests, increasing net primary production may reflect primarily the effects of climate warming. In that context, increasing temperatures are predicted to enhance the availability of nitrogen (Melilo et al. 1993), which is usually the limiting factor for plant growth in these ecosystems (Aber et al. 1989; Luo et al. 2004). Rising temperatures may also increase forest productivity at higher latitudes by extending the length of the growing season (Cannell et al. 1998).

While elevated $\mathrm{CO}_{2}$ concentrations and higher temperatures are likely to increase forest productivity, other components of climate change might have contrary effects. Water availability is a major limiting factor for plant growth in many forest ecosystems (Stephenson 1990; Xiao and Moody 2004). In forest trees of Central Europe, moderate drought stress has been mainly restricted to relatively short periods during summer until now. However, in the frame of climate change, the frequency and severity of summer drought events is expected to increase in future (Christensen and Christensen 2003; Rowell and Jones 2006). Increasing photosynthesis and evapotranspiration rates, as expected to occur under global warming in temperate regions may lead to an additional reduction of soil moisture, and therefore intensify soil drought in Central European forests (Hungate et al. 1997; Yang et al. 2003). However, it has been shown that plants adapt to water deficiency by reducing transpiration or increasing leaf-specific hydraulic conductivity (Tyree and Sperry 1988). Reduced carbon assimilation and respiration due to soil drought may lead to a degradation of non-structural carbohydrate pools and limit forest productivity (Parker and Patton 1975; Schulze et al. 1987). Drought may also increase the susceptibility of trees to secondary stressors and forest fires (Stocks et al. 1998; Dale et al. 2001; Rouault et al. 2006). Furthermore, reduced soil moisture is expected to cause major shifts in tree species composition, favouring those species adapted to water shortage (Stephenson 1990). Norway spruce (Picea abies) is known to be sensitive to drought. Investigating the exact effects of reduced soil moisture on Norway spruce might be particularly relevant because this tree species is very important for timber production. 
In many temperate forests of Europe, snow is an important regulator for biogeochemical processes during winter (Jones 1999). Snow packs keep the soil temperature constant and prevent soil frost (Marchand 1987). In addition, the melting of snow and ice provides moisture for biological activity in the soil. A reduction in snow cover associated with global warming may increase the intensity and frequency of freeze/thaw events in northern forests and therefore favour the occurence of "colder soils in a warmer world" (Groffman et al. 2001; Matzner and Borken 2008). Frost is expected to increase the mortality of soil microorganisms and fine roots (Christensen and Christensen 1991; Clein and Schimel 1995; Tierney et al. 2001), which may lead to enhanced rates of carbon and nitrogen mineralization after thawing because growth and activity of the surviving microbes are stimulated by the input of substrate (Dörsch 2004). In addition, soil freezing may contribute to acidification and nitrogen loss in forest ecosystems. In Canada, for example, canopy decline and decreased leaf areas in sugar maple trees were linked to elevated abscisic acid concentrations in xylem sap after extreme soil frost (Bertrand et al. 1994).

\section{The importance of fine roots for terrestrial carbon cycling}

Fine roots (often characterized as roots $<2 \mathrm{~mm}$ in diameter) do not only represent a pathway for water and nutrient uptake by plants, but they also play an important role in ecosystem carbon cycling (Schlesinger 1997). Fine root growth and maintenance requires a considerable amount of carbon, which is transferred to the soil after root death (Raich and Nadelhoffer 1989). Together with aboveground litter fall, root production provides the primary input of organic carbon to soils. In certain areas, root death may even contribute more carbon to forest soils than aboveground litter fall (Ruess et al. 2003). In addition, carbon derived from roots persists longer in the soil compared to leaf and shoot-derived carbon (Rasse et al. 2005). Due to these reasons, fine roots are increasingly recognized as a prominent sink for carbon acquired through terrestrial net primary production (Nadelhoffer and Raich 1992).

The importance of root systems for carbon cycling depends crucially on fine root longevity. Jackson et al. (1997) estimated that fine root growth may consume about 30 $\%$ of the carbon fixed by the canopy if fine roots live for one year on average. In accordance, Gill and Jackson (2000) analysed the results of 59 studies and found that estimated fine root longevity ranged from 5 months to 2 years. However, these studies were mainly based on traditional methods like soil coring and minirhizotron 
observations, which are considered to underestimate root longevity. Recently, isotopic approaches $\left({ }^{13} \mathrm{C}\right.$ and $\left.{ }^{14} \mathrm{C}\right)$ have increasingly been used as an alternative to measure fine root longevity directly from plant tissue (Gaudinski et al. 2001; Matamala et al. 2003; Joslin et al. 2006). Longevity estimates in the order of several years, as they are typically obtained by isotope-based studies have led to doubts about the enormous potential of fine roots for $C$ sequestration (Guo et al. 2008; Strand et al. 2008). Because the importance of reliable data on fine root longevity for quantifying carbon fluxes in forests is increasingly recognized, an intensive discussion on the efficacy of different methods has recently developed. Nowadays, it is mainly accepted that all of the current methods have major shortcomings and that actual fine root longevity ranges between the results obtained from traditional approaches like soil coring and minirhizotron observations ( $\sim$ year) and those from isotopic approaches ( $\sim 5$ years).

\section{Effects of drought and frost on fine roots}

Fine roots of trees are not only important sources of carbon and nutrients for the rhizosphere biota, but they can also serve as sensitive indicators of environmental change. In many cases, fine roots respond more sensitively to changes in soil moisture, soil acidity, and temperature than the canopy. In addition, fine roots may mitigate the effects of climate change because they represent a potential sink for anthropogenic emissions of carbon dioxide. However, our understanding of belowground carbon transfer processes is still limited especially with respect to the dependency of root dynamics on abiotic stress such as drought and frost. This knowledge is urgently needed because carbon storage and fluxes are of major importance regarding the effects of increasing drought intensities, changed winter precipitation regimes, eutrophication, soil acidification, and other environmental changes taking place or expected to do so in the near future (Davidson et al. 2002; Guo et al. 2005; Lal 2005). Changes in fine root dynamics could affect either directly or indirectly plant growth, tree vigor and carbon sequestration. It is therefore essential to improve our knowledge of drought and frost effects on fine root turnover and the related carbon fluxes in soils.

Bloomfield et al. (1996) conclude from a literature review that fine root longevity decreases with a decrease in soil moisture, indicating a more rapid root turnover upon drought. Meier and Leuschner (2008) also found that Fagus sylvatica fine roots had a shorter longevity when exposed to drought. In contrast, Lauenroth and Gill (2003) conclude from a meta-analysis that fine root turnover in forests is not related to 
precipitation or water availability. Thus, the dependency on water availability of fine root biomass and dynamics is not fully understood in forest ecosystems. Mainero and Kazda (2006) studied fine root production and mortality of European beech within the dry year 2003. According to their results, root formation was influenced by both, soil temperature and soil water content. In Norway spruce, fine root growth was found to decrease during a severe drought (Blanck et al. 1995). In addition, Persson et al. (1995) and Davies and Bacon (2003) reported a shift downward in spruce fine root biomass as a consequence of water shortage. In a meta-analysis of fine root biomass data of spruce in Central Europe, Leuschner and Hertel (2003) found a general decrease in stand fine root biomass towards sites with lower rainfall. However, comprehensive data on the responses of the root systems of spruce and other temperate tree species to drought under precisely defined soil moisture conditions are scarce.

Snow covers prevent soil from freezing and assure relatively constant soil temperatures in many temperate and boreal forests (Stadler et al. 1996). As a consequence, fine root mortality is lowest during winter in these ecosystems (Hendrick and Pregitzer 1992; Fahey and Hughes 1994). Most research concerning frost effects on fine root growth and physiology has been conducted with potted Picea and Pinus tree seedlings that were exposed to cold treatments of limited duration. In these studies, optimum temperature for root growth was shown to be lower than for shoot growth although roots were much less cold tolerant than needles, shoots and the stem cambium (Lindström 1986; Bigras and Dumois 2005). Up to now, information on the response of the root systems of mature trees to soil frost is scarce. Tierney et al. (2001) found that fine root mortality and turnover were accelerated by experimentally enhanced frost in a temperate deciduous forest of North America resulting in considerable excess fluxes of carbon and nitrogen to the soil. Boutin and Robitaille (1995) removed snow in a sugar maple stand and suggested that fine root mortality due to soil frost may have led to canopy dieback and elevated loss of nutrients from the system. In agreement, Groffman et al. (2001) conclude that elevated fine root mortality during freezing may substantially alter biogeochemical processes in the soil after thawing. 


\section{Study site}

The study described in this thesis was conducted in an old-growth Norway spruce (Picea abies (L.) Karst.) forest in the Fichtelgebirge mountains in Southeast Germany (Figure 1). The forest is located at $770 \mathrm{~m}$ a.s.l.; annual precipitation is $1160 \mathrm{~mm}$ and average annual air temperature is $5.3^{\circ} \mathrm{C}$ (Foken 2003).

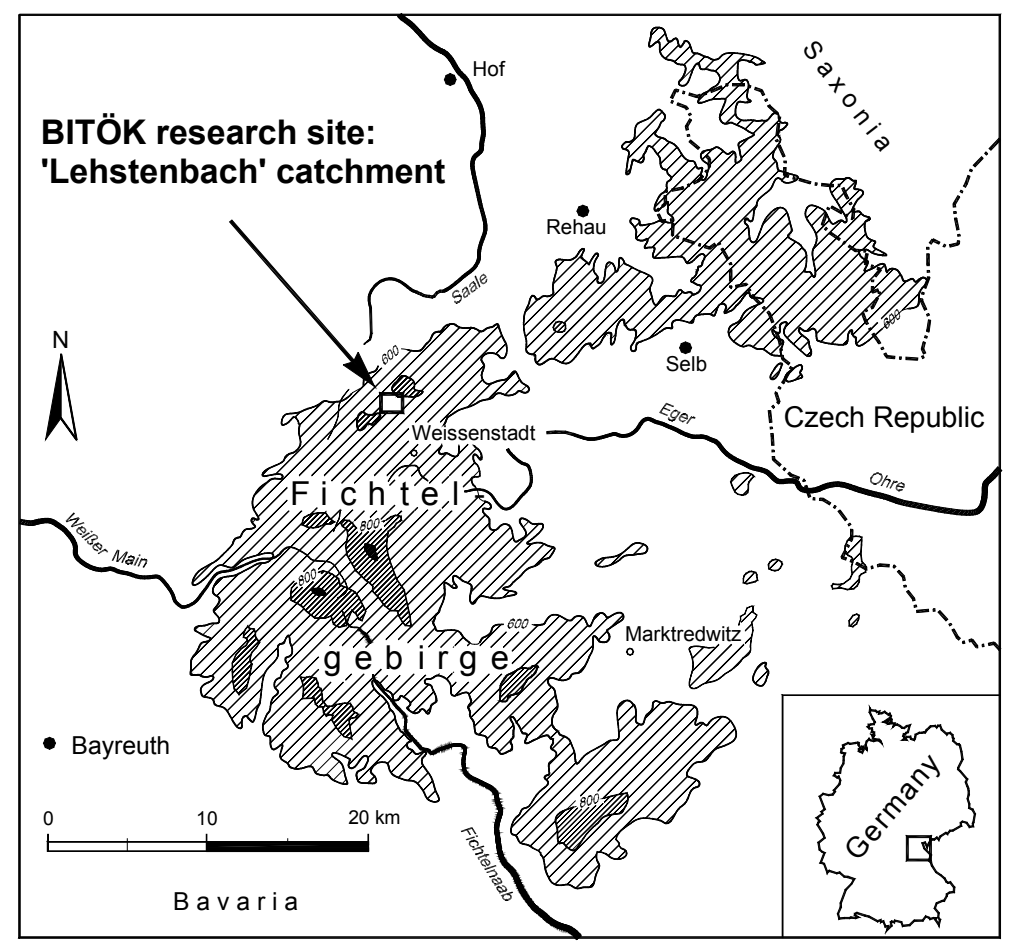

Figure 1: Overview of the study area in the Fichtelgebirge mountains. The arrow points to the study site.

The pure spruce forest consists of 140-yr-old trees with a dense canopy cover and a mean tree height of approximately $30 \mathrm{~m}$. The basal area is $45 \mathrm{~m}^{2} \mathrm{ha}^{-1}$ and the stem density is approximately $350 \mathrm{ha}^{-1}$. The patchy ground vegetation is dominated by the grass species Deschampsia flexuosa (L.) and Calamagrostis villosa (Chaix). The soil is derived from granite and is classified as Albic Rustic Podsol (FAO, 2006). The texture of the acidic soil is sandy to loamy with $\mathrm{pH}$-values $\left(\mathrm{H}_{2} \mathrm{O}\right)$ ranging between 4.0 in the $\mathrm{Oa}$ horizon and 4.5 in the Bw horizon (Hentschel et al. 2007). The thick organic layer (Oi, $\mathrm{Oe}, \mathrm{Oa}$ ) comprises approximately $10 \mathrm{~cm}$. The base saturation is highest in the $\mathrm{Oa}$ horizon with $54 \%$ and decreased to $12-16 \%$ in the subsoil (Hentschel et al. 2007). The stand, however, was not directly limed, but might have received an unknown dose of dolomite in 1994 and 1999, when surrounding stands were limed. Carbonate was analytically not detectable in the top soil. The carbon and nitrogen contents of the soil 
decrease with depth from $18 \% \mathrm{C}$ and $1 \% \mathrm{~N}$ in the Oa horizon to $0.4 \% \mathrm{C}$ and $<0.05 \%$ $\mathrm{N}$ in the BW horizon (Hentschel et al. 2007).

\section{Experimental design}

In order to investigate the effects of drought and frost on fine root dynamics and carbon fluxes in the studied spruce stand, nine research plots of approximately $20 \mathrm{~m} \mathrm{x} 20 \mathrm{~m}$ were selected, representing three treatments (throughfall exclusion, snow removal, control) in triple replication. For every plot, one transect of about $13 \mathrm{~m} \times 1 \mathrm{~m}$ was demarcated to monitor fine root dynamics.

Summer drought was simulated using three roofs of about $3 \mathrm{~m}$ height to exclude throughfall from the complete area of the treatment plots during summer 2006. Rainwater falling on the roofs during this period was channeled through rain gutters and water pipes before it could soak into the ground outside the plots. After about $70 \mathrm{~mm}$ of rainfall had been excluded from the treatment plots, the roof panels were removed to allow for rewetting of the soil by normal throughfall. In addition, artificial rewetting with $67 \mathrm{~mm}$ of water for a period of two days immediately after the end of the soil drought period guaranteed that the total annual water input was similar at the throughfall exclusion and control plots.

Soil frost was induced by manual snow removal during winter 2005/2006. In order to avoid the removal of forest floor by shoveling, the soil was protected by grid frames at the treatment plots. In addition, the root transects were covered by rooflets of about 50 $\mathrm{cm}$ height to prevent minirhizotron tubes and other installations from being damaged. After the end of the treatment, snow was allowed to accumulate at all plots until natural melting in spring. Soil temperatures in the forest floor were monitored by temperature data loggers during the complete study.

In addition, fine root longevity with root diameter, root $\mathrm{C} / \mathrm{N}$ ratio and soil depth was investigated at the control plots using three different methods (sequential soil coring, minirhizotron observations and radiocarbon analyses). 


\section{Study objectives and hypothesis}

This study was conducted in the framework of the Research Group 562 "Soil processes under extreme meteorological conditions" of the German Research Foundation (DFG). The interdisciplinary research group comprised soil scientists, hydrologists, microbiologists and plant ecologists from the universities of Bayreuth, Jena and Göttingen. The major aim of the project was to investigate the consequences of extreme meteorological boundary conditions for element turnover in forest and fen soils. As a member of the research group, I focused on fine roots and their response to experimentally induced drought and frost.

The aims of my work were:

(1) to investigate the effects of experimental soil drought and soil frost on fine root dynamics in a mature forest

(2) to assess the impact of drought and frost induced root mortality on carbon and nitrogen fluxes in the soil

(3) to identify the potential of different methods for estimating fine root longevity

I tested the hypotheses that (i) soil drought and soil frost increase fine root mortality, leading to a higher input of root-born organic matter into the soil and that (ii) drought and frost induced fine root mortality is compensated by higher rates of fine root production, thereby increasing the carbon sink strength of the root system due to a higher fine root turnover. 


\section{References}

Aber, J.D., Nadelhoffer, K.J., Steudler, P., Melillo, J.M. 1989. Nitrogen saturation in northern forest ecosystems. Bioscience 39, 378-386.

Bertrand, A., Robitaille, G., Nadeau, P., Boutin, R. 1994. Effects of soil freezing and drought stress on abscisic acid content of sugar maple sap and leaves. Tree Physiology, 14, 413-425.

Bigras, F.J., Dumais, D. 2005. Root-freezing damage in the containerized nursery: impact on plantation sites - A review. New Forests 30, 167-184.

Blanck, K., Lamersdorf, N., Dohrenbusch, A., Murach, D. 1995. Response of a Norway spruce forest ecosystem to drought/rewetting experiments at Solling, Germany. Water, Air and Soil Pollution 85, 1251-1256.

Bloomfield, J., Vogt, K., Wargo, P.M., 1996. Tree root turnover and senescence. In: Waisel, Y., Eshel, A., Kafkafi, U. (Eds.), Plant roots: the hidden half. Dekker, New York, pp. 363-381.

Bonan, G.B. 2008. Forest and climate change: Forcings, feedbacks, and the climate benefits of forests. Science, 320, 1444-1449.

Boutin, R. Robitaille, G. 1994. Increased soil nitrate losses under mature sugar maple trees affected by experimentally induced deep frost. Canadian Journal of Forest Research 25, 588-602.

Cannell, M.G.R., Thornley, J.H.M., Mobbs, D.C, Friend, A.D. 1998. UK conifer forests may be growing faster in response to increased $\mathrm{N}$ deposition, atmospheric $\mathrm{CO} 2$ and temperature. Forestry 71, 277-296.

Christensen, S., Christensen, B.T. 1991. Organic matter available for denitrification in different soil fractions: effect of freeze/thaw cycles and straw disposal. Journal of Soil Science 42, 637-647.

Christensen, J.H., Christensen, O.B. 2003. Climate modelling: Severe summertime flooding in Europe. Nature 421, 805-806.

Clein, J.S., Schimel, J.P. 1995. Microbial activity of tundra and taiga soils at sub-zero temperatures. Soil Biology and Biochemistry 27, 1231-1234.

Colombo, S.J., Zhao, S., Blumwald, E. 1995. Frost hardiness gradients in shoots and roots of Picea mariana seedlings. Scandinavian Journal of Forest Research 10, 32-36.

Cooley, K.R. 1990. Effects of CO2-induced climate changes on snowpack and streamflow. Hydrological Science Journal 35, 511-522.

Crowley, J. 2000. Causes of climate change over the past 1000 years. Science 289, 270-277.

Curtis, P.S., Wang, X. 1998. A meta-analysis of elevated CO2 effects on woody plant mass, form, and physiology. Oecologia 113, 299-313. 
Dale, V.H., Joyce, L.A., McNulty, S., Neilson, R.P., Ayres, M.P., Flannigan, M.D., Hanson, P.J., Irland, L.C., Lugo, A.E., Peterson, C.J., Simberloff, D., Swanson, F.J., Stocks, B.J., Wotton, B.M. 2001. Climate change and forest disturbances. Bioscience 51, 723-734.

Davidson, E.A., Savage, K., Bolstad, P., Clark, D.A., Curtis, P.S., Ellsworth, D.S., Hanson, P.J., Law, B.E., Luo, Y., Pregitzer, K.S., Randolph, J.C., Zak, D. 2002. Belowground carbon allocation in forests estimated from litterfall and IRGA-based soil respiration measurements. Agricultural and Forest Meteorology 113, 39-51.

Davies, W.J., Bacon, M.A., 2003. Adaptation of roots to drought. In De Kroon, H., Visser, E.J.W. (Eds.), Root Ecology. Ecological Studies 168. Springer Verlag, Berlin, pp. 173-192.

Denton, G. H., Karlen, W. 1973. Holocene Climatic Variations-Their Pattern and Possible Cause. Quaternary Research 3, 155-205.

Dixon, R.K., Brown, S., Houghton, R.A., Solomon, A.M., Trexler, M.C., Wisniewski, J. 1994. Carbon pools and flux of global forest ecosystems. Science 263, 185-190.

Dörsch, P. 2004. Overwintering greenhouse gas fluxes in two contrasting agricultural habitats. Nutrient Cycling in Agroecosystems 70, 117-133.

Fahey, T.J., Hughes, J.W. 1994. Fine-root dynamics in a northern hardwood forest ecosystem, Hubbard Brook Experimental Forest, Nh. Journal of Ecology 82, 533-548.

Foken, T. 2003. Lufthygienisch-Bioklimatische Kennzeichnung des oberen Egertales. Bayreuther Forum Ökologie 100, 1-118.

Free, M., Robock, A. 1999. Global warming in the context of the little Ice Age. Journal of Geophysical Research 104, 19057-19070.

Gaudinski, J.B., Trumbore, S.E., Davidson, E.A., Cook, A.C., Markewitz, D., Richter, D.D. 2001. The age of fine-root carbon in three forests of the eastern United States measured by radiocarbon. Oecologia 129, 420-429.

Gill, R.A., Jackson, R.B. 2000. Global patterns of root turnover for terrestrial ecosystems. New Phytologist 147, 13-31.

Groffman, P.M., Driscoll, C.T., Fahey, T.J., Hardy, J.P., Fitzhugh, R.D., Tierney, G.L. 2001. Colder soils in a warmer world: a snow manipulation study in a northern hardwood forest ecosystem. Biogeochemistry 56, 135-150.

Guo, D., Li, H., Mitchell, R.J., Han, W., Hendricks, J.J., Fahey, T.J., Hendrick, R.L. 2008. Fine root heterogeneity by branch order: exploring the discrepancy in root turnover estimates between minirhizotron and carbon isotopic methods. New Phytologist 177, 443-456.

Guo, L.B., Halliday, M.J., Siakimotu, S.J.M., Gifford, R.M. 2005. Fine root production and litter input: Its effects on soil carbon. Plant and Soil 272, 1-10.

Haeberli, W., Beniston, M. 1998. Climate change and its impacts on glaciers and permafrost in the Alps. Ambio 27, 258- 265. 
Hendrick, R.L., Pregitzer, K.S. 1992. The demography of fine roots in a northern hardwood forest. Ecology 73, 1094-1104.

Hentschel, K., Borken, W., Matzner, E. 2007. Leaching losses of inorganic N and DOC following repeated drying and rewetting of a spruce forest soil. Plant and Soil 300, 2134.

Hulme, M., Sheard, N. 1999. Climate change scenarios for Germany. Climatic Research Unit, Norwich, UK.

Hungate, B.A., Chapin, F.S., Zhong, H., Holland, E.A., Field, C.B, 1997. Stimulation of grassland nitrogen cycling under carbon dioxide enrichment. Oecologia 109, 149-153.

IPCC 2007. Climate change 2007: The physical basis - 4AR. Geneva, Switzerland: The Intergovernmental Panel on Climate Change.

Jackson, R.B., Mooney, H.A., Schulze, E.D. 1997. A global budget for fine root biomass, surface area, and nutrient contents. Proceedings of the National Academy of Sciences, USA 94, 7362-7366.

Johns, T.C., Gregory, J.M., Ingram, W.J., Johnson, C.E., Jones, A., Lowe, J.A., Mitchell, J.F.B., Roberts, D.L., Sexton, D.M.H., Stevenson, D.S., Tett, S.F.B., Woodage, M.J. 2001. Anthropogenic climate change for 1860 to 2100 simulated with the HadCM3 model under updated emission scenarios, Hadley Centre technical note.

Jones, H.G. 1999. The ecology of snow-covered systems: a brief overview of nutrient cycling and life in the cold. Hydrological Processes 13, 2135-2147.

Joslin, J.D., Gaudinski, J.B., Torn, M.S., Riley, W.J., Hanson, P.J. 2006. Fine-root turnover patterns and their relationship to root diameter and soil depth in a 14C-labeled hardwood forest. New Phytologist 172, 523-535.

Lal, R. 2005. Forest soils and carbon sequestration. Forest Ecology and Management 220, 242-258.

Lauenroth, W.K., Gill, R., 2003. Turnover of root systems. In: de Kroon, H., Visser, E.J.W. (Eds.). Root ecology. Ecological Studies 168. Springer, Berlin, pp. 61-90.

Leuschner, C., Hertel, D. 2003. Fine root biomass of temperate forests in relation to soil acidity and fertility, climate, age and species. Progress in Botany 64, 405-438.

Levitus, S., Antonov, J.L., Wang, J., Delworth, T.L., Dixon, K.W., Broccoli, A.J. 2001. Anthropogenic warming of Earth's climate system. Science 292, 267-270.

Lindström, A. 1986. Freezing temperatures in the root zone - effects on growth of containerized Pinus sylvestris and Picea abies seedlings. Scandinavian Journal of Forest Research 1, 371-377.

Lindström, A., Mattsson, A. 1989. Equipment for freezing roots and its use to test cold tolerance of young and mature roots of Picea abies seedlings. Scandinavian Journal of Forest Research 4, 59-66.

Luo, Y., Su, B., Currie, W.S., Dukes, J.S., Finzi, A., Hartwig, U., Hungate, B., McMurtrie, R.E., Oren, R., Parton, W.J., Pataki, D.E., Shaw, M.R., Zak, D.R., Field, C.B. 2004. 
Progressive nitrogen limitation of ecosystem responses to rising atmospheric carbon dioxide. Bioscience 54, 731-739.

Mainiero, R., Kazda, M. 2006. Depth-related fine root dynamics of Fagus sylvatica during exceptional drought. Forest Ecology and Management 237, 135-142.

Marchand, P.J. 1987. Life in the cold - An introduction to winter ecology. University Press of New England, Hanover, $\mathrm{NH}$.

Matamala, R., Gonzalez-Meler, M.A., Jastrow, J.D., Norby, R.J., Schlesinger, W.H. 2003. Impacts of fine root turnover on forest NPP and soil C sequestration potential. Science 302, 1385-1387.

Matzner, E., Borken, W. 2008. Do freeze-thaw events enhance C and N losses from soils of different ecosystems? - a review. European Journal of Soil Science 59, 274284.

Meier, I.C., Leuschner, Ch. 2008. Genotypic variation and phenotypic plasticity in the drought response of fine roots of European beech. Tree Physiology 28, 297-309.

Melillo, J.M., McGuire, A.D., Kicklighter, D.W., Moore, B., Vörösmarty, C.J., Schloss, A.L. 1993. Global climate change and terrestrial net primary production. Nature 363, 234-240.

Mooney, H. A., Drake, B. G., Luxmoore, R.J, Oechel, W.C., Pitelka, L.F. 1991. Predicting ecosystem responses to elevated CO2 concentrations. BioScience 41, 96104.

Nadelhoffer, K.J., Raich, J.W. 1992. Fine root production estimates and belowground carbon allocation in forest ecosystems. Ecology 73, 1139-1147.

Norby, R.J., Wullschleger, S.D., Gunderson, C.A., Johnson, D.W., Ceulemans, R. 1999. Tree responses to rising $\mathrm{CO} 2$ : implications for the future forest. Plant, Cell and Environment 22, 683-714.

Norby, R.J., DeLucia, E.H., Gielen, B., Calfapietra, C., Giardina, C.P., King, J.S., Ledford, J., McCarthy, H.R., Moore, D.J.P., Ceulemans, R., De Angelis, P., Finzi, A.C., Karnosky, D.F., Kubiske, M.E., Lukac, M., Pregitzer, K.S., Scarascia-Mugnozza, G.E., Schlesinger, W.H., Oren, R. 2005. Forest response to elevated $\mathrm{CO}_{2}$ is conserved across a broad range of productivity. Proceedings of the National Academy of Sciences, USA 102, 18052-18056.

O'Brien, S.R., Mayewski, P.A., Meeker, L.D., Meese, D.A., Twickler, M.S. and Whitlow, S.I. 1995. Complexity of Holocene climate as reconstructed from a Greenland ice core. Science 270, 1962-64.

Parker, J., Patton, R.L. 1975. Effects of drought and defoliation on some metabolites in roots of black oak seedlings. Canadian Journal of Forest Research 5, 457-463.

Pastor, J., Post, W.M. 1988. Response of northern forests to $\mathrm{CO}_{2}$-induced climatic change: dependence on soil water and nitrogen availability. Nature 334, 55-58. 
Persson, H., Vonfircks, Y., Majdi, H., Nilsson, L.O. 1995. Root distribution in a Norway spruce (Picea-Abies (L.) Karst.) stand subjected to drought and Rammonium-Sulfate application. Plant and Soil 168-169, 161-165.

Raich, J.W., Nadelhoffer, K.J. 1989. Belowground carbon allocation in forest ecosystems - Global trends. Ecology 70, 1346-1354.

Rasse, D.P., Rumpel, C., Dignac, M.F. 2005. Is soil carbon mostly root carbon? Mechanisms for a specific stabilization. Plant and Soi 269, 341-356.

Rouault, G., Candau, J.N., Lieutier, F., Nageleisen, L.M., Martin, J.C., Warzee, N. 2006. Effects of drought and heat on forest insect populations in relation to the 2003 drought in western Europe. Annales of Forest Science 63, 613-624.

Rowell, D.P., Jones, R.G. 2006. Causes and uncertainty of future summer drying over Europe. Climate Dynamics 27, 281-299.

Ruess, R.W., Hendrick, R.L., Burton, A.J., Pregitzer, K.S., Sveinbjornsson, B., Allen, M.E., Maurer, G.E., 2003. Coupling fine root dynamics with ecosystem carbon cycling in black spruce forests of interior Alaska. Ecological Monographs 73, 643-662.

Schlesinger, W.H. 1997. Biogeochemistry. An analysis of global change, 2nd edition. Academic Press, San Diego.

Schulze, E.D., Robichaux, R.H., Grace, J. 1987. Plant water balance. BioSscience 37, 30-37.

Stadler, D., Wunderli, H., Auckenthaler, A., Fluhler, H. 1996. Measurement of frost induced snowmelt runoff in a forest soil. Hydrological Proceedings 10, 1293-1304.

Stager, C.J., Cumming, B. Meeker, L.D. 1997. A high-resolution 11,400-yr diatom record from Lake Victoria, East Africa. Quaternary Research 47, 81-89.

Stephenson, N.L. 1990. Climatic control of vegetation distribution: the role of the water balance. American Naturalist 135, 649-670.

Stocks, B.J., Fosberg, M.A., Lynham, T.J., Mearns, L., Wotton, B.M., Yang, Q., Jin, JZ., Lawrence, K., Hartley, G.R., Mason, J.A., and McKenney, D.W. 1998. Climate change and forest fire potential in Russian and Canadian boreal forests. Climate Change 38, 1-13.

Strand, A.E., Pritchard, S.G., McCormack, M.L., Davis, M.A., Oren, R. 2008. Irreconcilable differences: fine-root life spans and soil carbon persistence. Science 319, 456-458.

Teskey, R.O., Hinckley, T.M. 1981. Influence of temperature and water potential on root-growth of White oak. Physiologia Plantarum 52, 363-369.

Tierney, G.L., Fahey, T.J., Groffman, P.M., Fitzhugh, R.D., Driscoll, C.T. 2001. Soil freezing alters fine root dynamics in a northern hardwood forest. Biogeochemistry 56, 175-190. 
Tyree, M.T., Sperry, J.S. 1988. Do woody plants operate near the point of catastrophic xylem dysfunction caused by dynamic water stress? Answers from a model. Plant Physiology 88, 574-580.

Xiao, J.F., Moody, A. 2004. Photosynthetic activity of US biomes: responses to the spatial variability and seasonality of precipitation and temperature. Global Change Biology 10, 437-451.

Yang, Y.H., Watanabe, M., Wang, Z.P., Sakura, Y., Tang, C.Y. 2003. Prediction of changes in soil moisture associated with climatic changes and their implications for vegetation changes: waves model simulation on Taihang Mountain, China. Climatic Change 57, 163-183. 


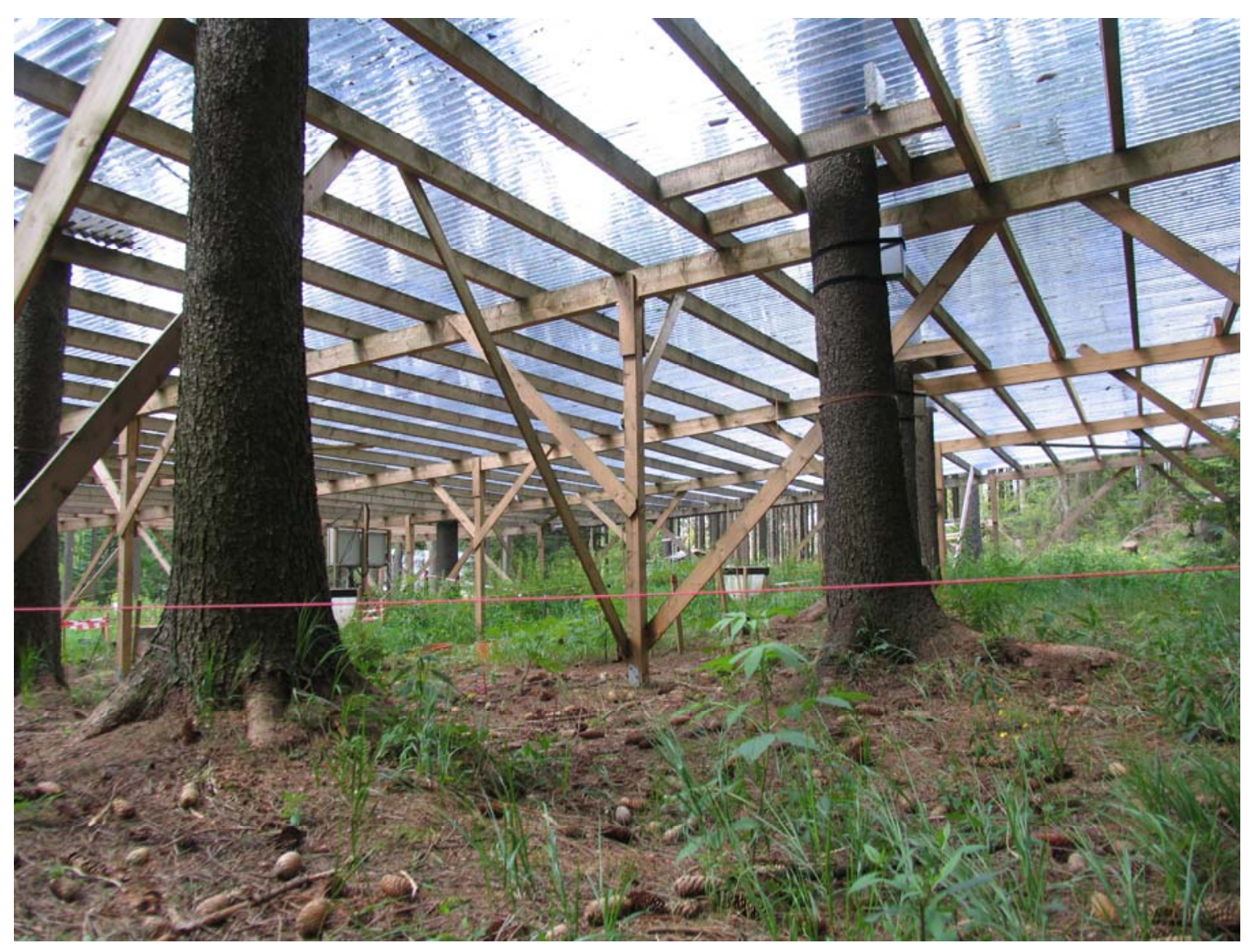




\title{
Chapter 2
}

Effects of experimental drought on the fine root system of mature Norway spruce

\author{
Dirk Gaul, Dietrich Hertel, Werner Borken, Egbert Matzner and \\ Christoph Leuschner
}

Forest Ecology and Management (accepted) 


\section{Summary}

Norway spruce (Picea abies (L.) Karst.) is an economically important, but relatively drought-sensitive tree species that might suffer from increasing drought intensities and frequencies, which are predicted to occur in parts of central Europe under future climatic change. In a throughfall exclusion experiment using sub-canopy roofs, we tested the hypothesis that enhanced drought leads to an increase in fine root mortality, and also to a higher, subsequent fine root growth. Fine root production and mortality were assessed using two independent approaches, sequential soil coring (organic layer) and direct observations in minirhizotrons (organic layer plus upper mineral soil). Six weeks of throughfall exclusion resulted in mild drought stress, i.e. a reduction in average soil moisture from 20 to 12 vol. \% during the treatment. Based on the sequential coring data, experimental drought did not result in significant changes in fine root biomass during the 6 -wk treatment period, but caused an increase in fine root mortality by $61 \%$ in the 6 weeks following the drought treatment. Remarkably, fine root production showed a synchronous increase in this period, which more than compensated for the loss due to increased mortality. The minirhizotron data confirmed that the drought treatment increased fine root loss in the organic layer. Based on this method, however, root loss occurred during the drought period and was not compensated by increased root production. The mild drought stress was mainly restricted to the organic layer and did not significantly influence fine root dynamics in the mineral soil. We calculated that the drought event resulted in an extra input of about $28 \mathrm{~g} \mathrm{C} \mathrm{m}^{-2}$ and $1.1 \mathrm{~g} \mathrm{~N} \mathrm{~m}^{-2}$ to the soil due to increased fine root mortality. We conclude that even periods of mild drought significantly increase fine root mortality and the associated input of root-derived $\mathrm{C}$ to the soil organic matter pool in temperate Norway spruce forests.

Key words: decomposition, fine root mortality, minirhizotrons, production, soil coring, throughfall exclusion 


\section{Introduction}

Fine roots play an important role in global carbon cycling because they are short-lived organs characterised by rapid turnover (Hendrick and Pregitzer, 1993; Gill and Jackson, 2000). Assuming that fine root longevity is one year, fine root production may constitute about $30 \%$ of the global net primary production (Jackson et al., 1997). Together with aboveground litter fall and the turnover of mycorrhizal hyphae, root production and mortality represent an important path of organic carbon input to soils. Thus, soil organic matter and root dynamics are tightly linked (Guo et al., 2005; Rasse et al., 2005). However, our understanding of below-ground $C$ transfer processes is still limited especially with respect to the regulation of root dynamics by abiotic stressors such as drought. This knowledge will become increasingly important since current scenarios of global climate change predict an increase in frequency and intensity of drought periods for various regions of the world (Rowell and Jones, 2006; IPCC, 2007). In Central Europe, a significant increase in the duration of summer drought periods is expected to take place in particular in the more continental regions (Hulme and Sheard, 1999; Christensen and Christensen, 2003). Drought-induced changes in fine root dynamics may affect tree growth and vitality. Altered growth dynamics could also affect carbon sequestration in forests. A deeper understanding of the drought tolerance of the fine root system of the main tree species is urgently needed.

Many reports on drought-induced dieback of fine roots in temperate and also tropical forests exist (e.g. Srivastava et al., 1986; Kummerov et al., 1990; Leuschner et al., 2001; Davies and Bacon, 2003). In one of the few throughfall exclusion experiments in temperate forests, Joslin and Wolfe (2003) found a reduction in fine root biomass and a displacement of root biomass to greater soil depth. On the other hand, a limited number of studies suggest that root growth can actually be increased by soil drying (e.g. Sharp and Davies, 1979). Bloomfield et al. (1996) conclude from a literature review that fine root longevity decreases with a decrease in soil moisture, indicating a more rapid root turnover upon drought. Meier and Leuschner (2008) found that fine roots of European beech (Fagus sylvatica L.) had a shorter longevity when exposed to drought. In contrast, Lauenroth and Gill (2003) conclude from a meta-analysis that fine root turnover in forests is not related to precipitation or water availability. Drought may also stimulate fine root growth in a wet period following a period of water shortage due to accumulation of non-structural carbohydrates in the roots during the drought (Kavanaugh and Kellman, 1992). In fact, a comparison of mature Douglas fir (Pseudotsuga mentziesii) stands differing in water supply revealed an increase in fine 
root turnover at sites exposed to frequent droughts (Santantonio and Hermann, 1985). Thus, the effects of water availability on fine root dynamics is not fully understood in forest ecosystems.

Norway spruce (Picea abies (L.) Karst.) is one of the economically most important tree species in Central Europe. It has been shown for this species that seasonal drought leads to a marked reduction in stem growth (Blanck et al., 1995; Spiecker, 1995; Alavi, 1996). However, the number of studies focussing on the drought sensitivity of the fine root system of Norway spruce is much smaller and data on the response of the root system of Norway spruce or other temperate tree species to drought under precisely defined soil moisture conditions is not sufficient to draw firm conclusions.

Nowadays, a number of independent methods is available for estimating growth, mortality and turnover of fine roots in forest soils including the direct observation of root growth and death in minirhizotrons, indirect mass-related techniques of estimating fine root turnover such as sequential root coring with "minimum-maximum" or "compartmental flow" calculation approaches, and experimental setups including ingrowth cores and root-growth chambers (Powell and Day, 1991; Hendrick and Pregitzer, 1992; 1993; Majdi, 1996; Hertel and Leuschner, 2006). All of these techniques have their advantages and shortcomings, and they may serve different purposes in fine root research (e.g. Hertel and Leuschner, 2002; Hendricks et al., 2006).

We conducted a replicated throughfall exclusion experiment to investigate the effects of mild drought on the fine root system of a mature Norway spruce stand. We employed two independent methods (sequential coring and minirhizotron observations) to monitor fine root dynamics over time. Using these methods in a combination, does not only allow us to determine the timing of root birth and death events, but also to estimate the total mass of fine roots turned over during the study period and, thus, to establish a quantitative link between fine root dynamics and biogeochemical fluxes in the soil.

Our aim was to test the hypotheses that (i) an increase in soil drought leads to higher fine root mortality and thereby increases the carbon input to the soil and that (ii) drought-induced mortality of fine roots is at least partly compensated by increased fine root production. 


\section{Materials and methods}

\section{Study site and experimental design}

The study was conducted in an old-growth Norway spruce forest in the Fichtelgebirge mountains in Southeast Germany $\left(50^{\circ} 08^{\prime} \mathrm{N}, 11^{\circ} 52^{\prime} \mathrm{E}\right)$. The forest is located at $770 \mathrm{~m}$ a.s.l.; average annual precipitation is $1160 \mathrm{~mm}$ and average annual air temperature is $5.3{ }^{\circ} \mathrm{C}$ (Foken, 2003). The pure spruce forest consists of 140-yr-old trees with a dense canopy cover and a mean tree height of approximately $30 \mathrm{~m}$. The patchy ground vegetation is dominated by the grass species Deschampsia flexuosa (L.) and Calamagrostis villosa (Chaix). Additional information about the aboveground vegetation structure of the research plots is given in Table 1.

Table 1: Characterization of the aboveground vegetation structure for the six research plots at the study site.

\begin{tabular}{lcccccc}
\hline & \multicolumn{4}{c}{ Throughfall exclusion } & \multicolumn{3}{c}{ Control } \\
& TE 1 & TE 2 & TE 3 & C 1 & C 2 & C 3 \\
\hline Plot size $\left(\mathrm{m}^{2}\right)$ & 406 & 387 & 380 & 308 & 342 & 392 \\
Number of trees & 14 & 11 & 9 & 6 & 12 & 17 \\
Stem density $\left(\mathrm{ha}^{-1}\right)$ & 345 & 284 & 237 & 195 & 351 & 433 \\
Basal area $\left(\mathrm{m}^{2} \mathrm{ha}^{-1}\right)$ & 43 & 45 & 32 & 30 & 45 & 58 \\
\hline
\end{tabular}

The soil is classified as Haplic Podsol (IUSS 2006) with silty loam in the uppermost soil and loamy sand beneath. The $\mathrm{pH}\left(\mathrm{H}_{2} \mathrm{O}\right)$ ranges between 4.0 in the Oa horizon and 4.5 in the Bw horizon (Hentschel et al., 2007). The thickness of the mor-like organic layer varies between 5 and $17 \mathrm{~cm}$ and averages at about $10 \mathrm{~cm}$. It is comprised of the Oi, Oe and Oa horizons.

In order to investigate the impacts of experimentally induced soil drought on fine root dynamics of spruce trees, six research plots of about $20 \mathrm{~m} \times 20 \mathrm{~m}$ each were established, of which three were chosen for a throughfall exclusion treatment and three as control plots. Three wooden roof structures of about $3 \mathrm{~m}$ height were covered with translucent plastic panels to simulate periods of enhanced summer drought by excluding throughfall from the complete area of the treatment plots between June $22^{\text {nd }}$ and August $8^{\text {th }}, 2006$. Rainwater falling on the roofs during this period was channeled through rain gutters and water pipes over a distance of about $35 \mathrm{~m}$ before it could soak into the ground outside the plots. After about $70 \mathrm{~mm}$ of rainfall had been excluded from the treatment plots in early August, the roof panels were removed to allow for rewetting 
of the soil by normal throughfall. In addition, artificial rewetting with $67 \mathrm{~mm}$ of water for a period of two days immediately after the end of the drought period guaranteed that the total annual water input was similar at the throughfall exclusion and control plots.

The soil moisture tension was monitored by two tensiometers per study plot and soil depth. At $20 \mathrm{~cm}$ mineral soil depth, the soil water matric potential was significantly lower in the throughfall exclusion plots than in the control plots during the period of experimentally induced drought (Figure 1). After rewetting, these differences disappeared within 24 hours. At $40 \mathrm{~cm}$ and $90 \mathrm{~cm}$ mineral soil depth, the soil water matric potential was similar for both plot types during the complete measuring period (data not shown). Mean daily soil temperature in the organic layer at $6 \mathrm{~cm}$ depth measured by four temperature data loggers (DS 1921 Thermochron iButtons, Fa. Dallas Semiconductor, USA) per plot was similar in treatment and control plots during the complete study period (Figure 1).

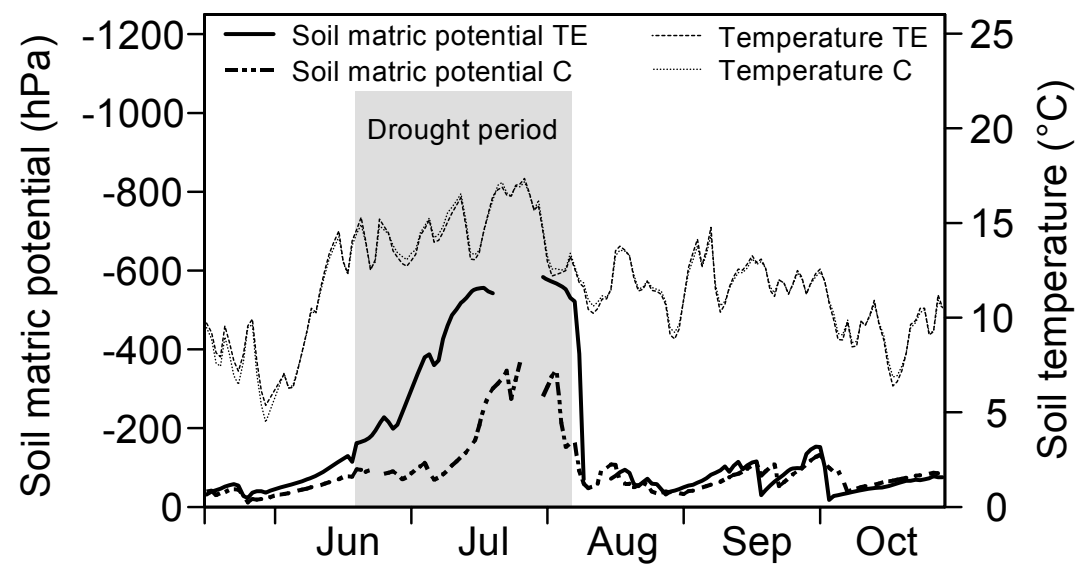

Figure 1: Soil matric potential (bold lines) in $20 \mathrm{~cm}$ soil depth and soil temperature (thin lines) in the organic layer for throughfall exclusion (TE, full line) and control plots (C, dotted line) from mid May until the end of October 2006. The period of experimental drought is marked in grey.

\section{Fine root inventory}

In summer 2005, an inventory of mass and vertical distribution of the fine root $(d<2$ $\mathrm{mm}$ ) system was carried out in all six study plots to examine site comparability. In the center of every plot, a transect of $13 \mathrm{~m}$ length and $1 \mathrm{~m}$ width was randomly chosen for all fine root studies. Samples were taken with a soil corer $(3.5 \mathrm{~cm}$ in diameter) from the organic layer and the upper $40 \mathrm{~cm}$ of the $40-80 \mathrm{~cm}$ deep mineral soil at 12 randomly selected locations along each transect. The sampling locations were at least $50 \mathrm{~cm}$ apart to avoid interference between the coring locations. After transferring the root 
samples to plastic bags, they were transported to the laboratory where they were stored at $4{ }^{\circ} \mathrm{C}$ and processed within five weeks. In the laboratory, the samples were washed with water in a sieve (0.25 mm mesh size) to remove soil particles. Under a stereomicroscope, large roots (> $1 \mathrm{~cm}$ in length) were sorted into living (biomass) and dead (necromass) fractions based on their color, elasticity and degree of cohesion of cortex, periderm and stele (Persson, 1978; Leuschner et al., 2001). While this analysis covers the vast majority of fine root biomass, large amounts of small dead rootlets are not considered. In order to include also roots $<1 \mathrm{~cm}$ in length, half of the samples were examined additionally by a more detailed procedure according to Hertel and Leuschner (2004). The results were then extrapolated to estimate the biomass and necromass of fine roots $<1 \mathrm{~cm}$ in length for the remaining samples. Fine root biomass and necromass of each sample was dried at $70^{\circ} \mathrm{C}$ for $48 \mathrm{~h}$ and weighed. The data were expressed as fine root abundance $\left(\mathrm{g} \mathrm{m}^{-2}\right)$.

In addition, fine root biomass samples from the organic layer were ground and analyzed for carbon and nitrogen content using a $\mathrm{CNH}$ auto-analyzer.

\section{Fine root dynamics}

Fine root dynamics were monitored in the organic layer (sequential coring and minirhizotron observations) and the upper ca. $25 \mathrm{~cm}$ of the mineral soil (minirhizotron observations). We randomly selected 20 sampling locations in each of the six root transects to monitor changes in fine root biomass and necromass over time using the sequential coring method (Persson, 1978; McClaugherty et al., 1982). Soil cores from all plots were collected in the same way as described above at the beginning and the end of throughfall exclusion (June $22^{\text {nd }}$ and August $8^{\text {th }}, 2006$ ) as well as six weeks after rewetting (September 22 ${ }^{\text {nd }}, 2006$ ). Additionally, we took samples at the end of the study (December $9^{\text {th }}, 2006$ ) to cope with the problem of delayed visual appearance of root death. The four consecutive samples of a given coring location were taken at a distance of $30 \mathrm{~cm}$ to each other. Production and mortality were calculated based on changes in fine root biomass and necromass between sampling dates using the balancing transfer method (Fairley and Alexander, 1985). We classified the interval between the first and the second sampling date as drought period, the interval between the second and the third sampling date as post-drought period and the interval between the third and the last sampling date as follow-up period. Fine root turnover is usually calculated by relating root production during a certain period of time to fine root biomass (Aber et al., 1985; Aerts et al., 1992). In our study, however, we expected to observe an impact of 
drought on fine root mortality first, followed by compensatory fine root production at a later stage. Therefore, we estimated fine root turnover by dividing fine root mortality during both the 6-wk-period of experimental drought and the subsequent 6-wk postdrought period by the mean standing fine root biomass during this period (Nadelhoffer, 2000).

The minirhizotron technique was used for observing fine root growth and disappearance directly at the surface of transparent plastic tubes. In June 2005, eight minirhizotron tubes (67 cm long $\times 7.0 \mathrm{~cm}$ wide) per plot were installed at randomly selected locations along each transect. The tubes were positioned vertically to the soil surface to obtain accurate intersections with the mainly horizontally orientated root system of Norway spruce (Majdi et al., 2000). To ensure that the tubes were in tight contact with the soil, holes were made with a soil corer of the same outer diameter as the minirhizotrons. The tubes were closed by removable plastic caps at the top and sealed at the bottom to avoid the entrance of water. The aboveground parts of the minirhizotron tubes were covered with tape to prevent the penetration of sunlight. Between June and September 2006 , images of the fine root system in proximity to the tubes were taken on five dates (June $22^{\text {nd }}$, July $13^{\text {th }}$, August $6^{\text {th }}$, September $5^{\text {th }}$, September $22^{\text {nd }}$ ) with a root scanner system (Cl-600 Root Growth Monitoring System, CID, USA). The colored images with a resolution of 200 dpi were collected for almost the entire belowground tube surface $\left(345^{\circ}\right)$ in the organic layer and the upper ca. $25 \mathrm{~cm}$ of the mineral soil, which is equivalent to a total surface area of $735 \mathrm{~cm}^{2}$ per tube.

Continuous sections covering the complete length and approximately $35 \%$ of the width of these pictures (i.e. a total surface area of $257 \mathrm{~cm}^{2}$ per tube and date) were randomly chosen and analyzed with the software WinRhizo Tron (Régent, Quebec, Canada) to monitor changes in fine root length over time. Due to the inherent difficulties of distinguishing between live and dead roots on minirhizotron images (Tingey et al., 2000), we refrained from this division and fine roots ( $<2 \mathrm{~mm}$ in diameter) were only divided into present and gone. In accordance with the classification adapted in the sequential coring study, we termed the interval between the first and the third image collection as drought period, the interval between the third and the fourth image collection as post-drought period \#1 and the interval between the fourth and the last image collection as post drought period \#2. By comparing the length of visible and disappeared fine roots of current and previous images, total root production and root loss were calculated (Majdi, 1996). Relative loss or production was calculated as the ratio between total fine root loss or production during a given period and the standing root length at the beginning of this period (Hendricks et al., 2006). Fine root turnover 
was calculated by relating the total length of fine roots, which disappeared between the first and the last date of image collection, to the mean standing fine root length during this period (Nadelhoffer, 2000).

\section{Fine root decomposition}

In order to investigate the impact of experimental drought on fine root decomposition, we conducted a root litterbag experiment. On September $8^{\text {th }}, 2005$, soil cores of the organic layer were collected in proximity to the research plots, transferred to plastic bags and transported to the laboratory, where they were stored at $4{ }^{\circ} \mathrm{C}$. The fine root material was separated from soil residues using a sieve of $0.5 \mathrm{~cm}$ in mesh size. Then, 58 polyethylene litterbags $(5 \mathrm{~cm} \times 5 \mathrm{~cm} ; 0.15 \mathrm{~mm}$ mesh-size) were filled with each $3.5 \mathrm{~g}$ (wet mass) of mixed living and dead fine root material. Six days after collecting the soil cores (on September $14^{\text {th }}, 2005$ ), 8 root litterbags per plot were exposed at about $5 \mathrm{~cm}$ below the organic layer surface in the throughfall exclusion and control plots. On September $10^{\text {th }}$ and December $9^{\text {th }}, 2006$, four litterbags per plot and date were recollected after being exposed to the soil for 360 and 450 days, respectively. After they were dried at $70{ }^{\circ} \mathrm{C}$ for 48 hours, the root material was taken out of the litterbags, weighed and the mass loss calculated.

The remaining litterbags $(n=10)$ were dried at $70{ }^{\circ} \mathrm{C}$ for 48 hours directly after they had been filled, the root material was taken out of the litterbags and also weighed. The mean ratio between wet and dry fine root mass of these litterbags was used as a wet mass to dry mass conversion factor for the remaining samples.

\section{Statistical analysis}

According to the Shapiro-Wilk test, all data sets except for fine root decomposition were not normally distributed. Even after log or root transformation, most data sets were still skewed. Therefore we used non-parametric Mann-Whitney two-sample tests with a rejection level of $5 \%$ to detect significant differences in standing stock, (relative) production and (relative) mortality of fine roots between the treatment and control plots and between different dates. ANOVA followed by a Scheffé $f$-test were used to compare the normally-distributed data on fine root decomposition between treatment and control at a $5 \%$ rejection level. All calculations were conducted with the software package SAS, version 8.2 (SAS Institute, Cary, NC, USA). 


\section{Results}

\section{Inventory of fine root biomass and necromass}

Nine months before the onset of the throughfall exclusion experiment, soil coring did not reveal any significant differences in fine root biomass and necromass between the treatment and control plots (data not shown). Fine root biomass totals of $382 \pm 29 \mathrm{~g} \mathrm{~m}^{-2}$ and $439 \pm 40 \mathrm{~g} \mathrm{~m}^{-2}$ (organic layer plus upper $40 \mathrm{~cm}$ of mineral soil) were measured in the treatment and control plots, respectively. Fine root biomass was very similar in the organic layer of treatment and control plots $\left(189 \pm 15 \mathrm{~g} \mathrm{~m}^{-2}\right.$ and $\left.179 \pm 19 \mathrm{~g} \mathrm{~m}^{-2}\right)$ but tended to be higher by $35 \%$ in the mineral soil of the control plots compared to the treatment plots. Similarly, fine root necromass values were comparable in the organic layers of the treatment and control plots $\left(231 \pm 19 \mathrm{~g} \mathrm{~m}^{-2}\right.$ and $\left.226 \pm 16 \mathrm{~g} \mathrm{~m}^{-2}\right)$, and slightly higher in the mineral soil of the control plots $\left(324 \pm 20 \mathrm{~g} \mathrm{~m}^{-2}\right)$ compared to the treatment plots (291 $\pm 29 \mathrm{~g} \mathrm{~m}^{-2}$; data not shown).

In both plot types, fine root biomass density was highest in the organic layer and decreased exponentially with depth (Figure 2). This is reflected by the relatively low $\beta$ values $(0.93-0.94)$ of the fine root biomass depth function $y=1-\beta^{d}$ according to Gale and Grigal (1987), where y represents the cumulative portion of standing fine root biomass in the respective soil depth $\mathrm{d}$.

Cumulative fine root biomass (\%)

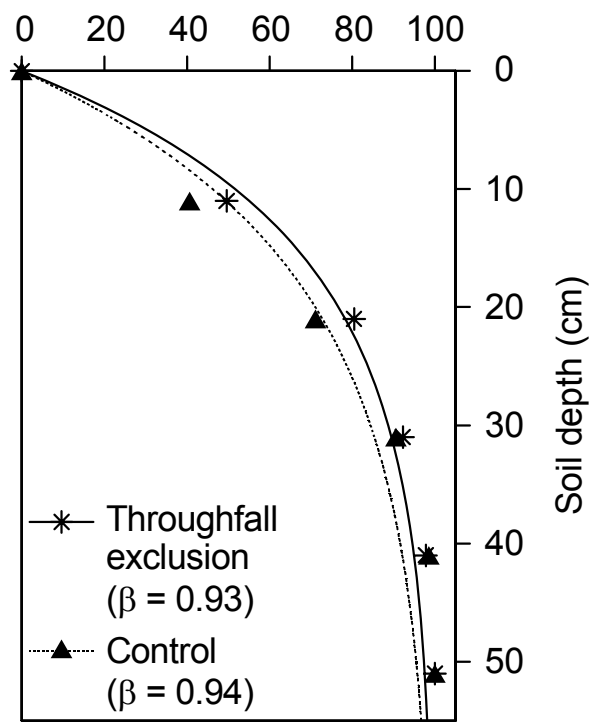

Figure 2: Cumulative vertical fine root biomass distribution up to $50 \mathrm{~cm}$ soil depth. Throughfall exclusion and control plots were investigated by soil coring approximately nine months before the application of experimental drought. The steepness of the fine root biomass decrease with depth is expressed by the $\beta$-value of the regression equation $y=1-\beta^{\mathrm{d}}$ (see Gale and Grigal, 1987), with $\mathrm{y}=$ cumulative fine root biomass fraction in $\mathrm{g} \mathrm{m}^{-2}$ and $\mathrm{d}=$ soil depth in $\mathrm{cm}$. Note that the upper $10 \mathrm{~cm}$ of the soil profile represent the organic layer. 
The mean $\mathrm{C} / \mathrm{N}$ ratio of the root biomass samples was $24 \pm 0.5$ in the organic layer and the carbon and nitrogen concentrations of the living roots were $46 \%$ and $1.9 \%$, respectively, with no significant differences between the treatment and control plots (data not shown).

\section{Dynamics of living and dead fine roots (sequential coring data)}

At the beginning of experimental drought, fine root biomass was very similar in the treatment and control plots (182 $\mathrm{g} \mathrm{m}^{-2}$ versus $179 \mathrm{~g} \mathrm{~m}^{-2}$; Figure $3 \mathrm{~A}$ ). Towards the end of the experimental drought, fine root biomass remained stable in the treatment plots but decreased by $33 \%$ in the control plots. After rewetting, fine root biomass significantly increased again in the treatment and control plots and the differences in fine root biomass between both plot types decreased slightly with time (48\% at the end of the treatment; $32 \%$ six weeks after rewetting and $26 \%$ four months after rewetting). However, even on the last sampling date in December 2006, fine root biomass was still significantly higher in the throughfall exclusion compared to the control plots.
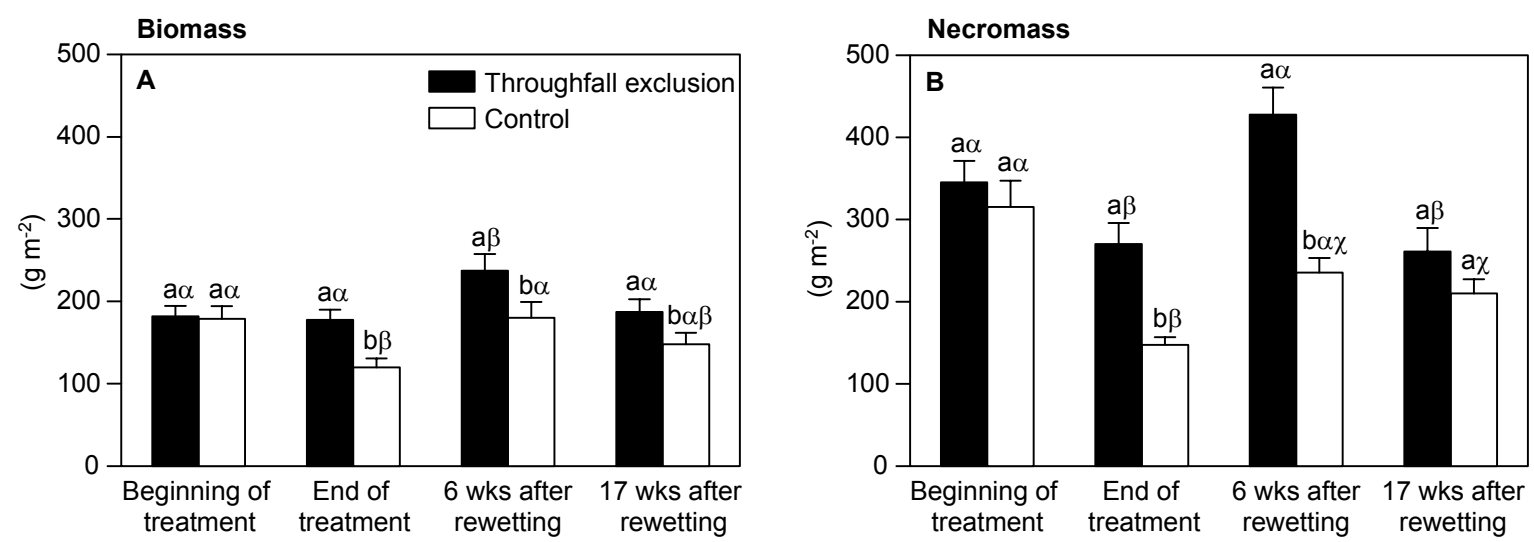

Figure 3: Fine root biomass (A) and necromass (B) in the organic layer of throughfall exclusion and control plots (mean + SE) as investigated by sequential coring. Samples were collected at the beginning and at the end of the experimental drought (June $22^{\text {nd }}$ and August $8^{\text {th }}$ ), 6 weeks after rewetting (September $22^{\text {nd }}$ ) and 17 weeks after rewetting (December $9^{\text {th }}$ ). Different Latin letters indicate significant differences $(\mathrm{p}<0.05)$ between the treatments at a given date, different Greek letters those between different dates for a given treatment.

The impact of experimental drought on fine root necromass was similar but even more pronounced. During the drought period, fine root necromass in the throughfall exclusion and control plots decreased by $22 \%$ and $53 \%$, respectively (Figure $3 \mathrm{~B}$ ). As a result, fine root necromass was significantly higher (by $82 \%$ ) in the throughfall exclusion plots compared to the controls. Six weeks after rewetting, dead root mass was found to be 
still significantly higher in both plot types. At the end of the year, fine root necromass reached similar size in the throughfall exclusion and control plots.

As a consequence of the observed changes in fine root biomass and necromass, fine root mortality was similar for both plot types during the experimental drought, but significantly higher during the post-drought period in the treatment than in the control plots (106 vs. $66 \mathrm{~g} \mathrm{~m}^{-2} \mathrm{mo}^{-1}$; Figure $4 \mathrm{~A}$ ). In the follow-up period from September until December 2006, the fine root mortality rate decreased again in both plot types and approached values as observed during the previous drought period; the difference between treatment and control plots disappeared.

Similar to fine root mortality, root production rates were highest in both treatments during the post-drought period (Figure $4 \mathrm{~B}$ ). However, during the drought period, fine root production was significantly increased by a factor of four in the treatment plots compared to the control plots. Fine root production tended also to be higher (by $39 \%$ ) in the throughfall exclusion plots compared to the control plots during the post-drought period.
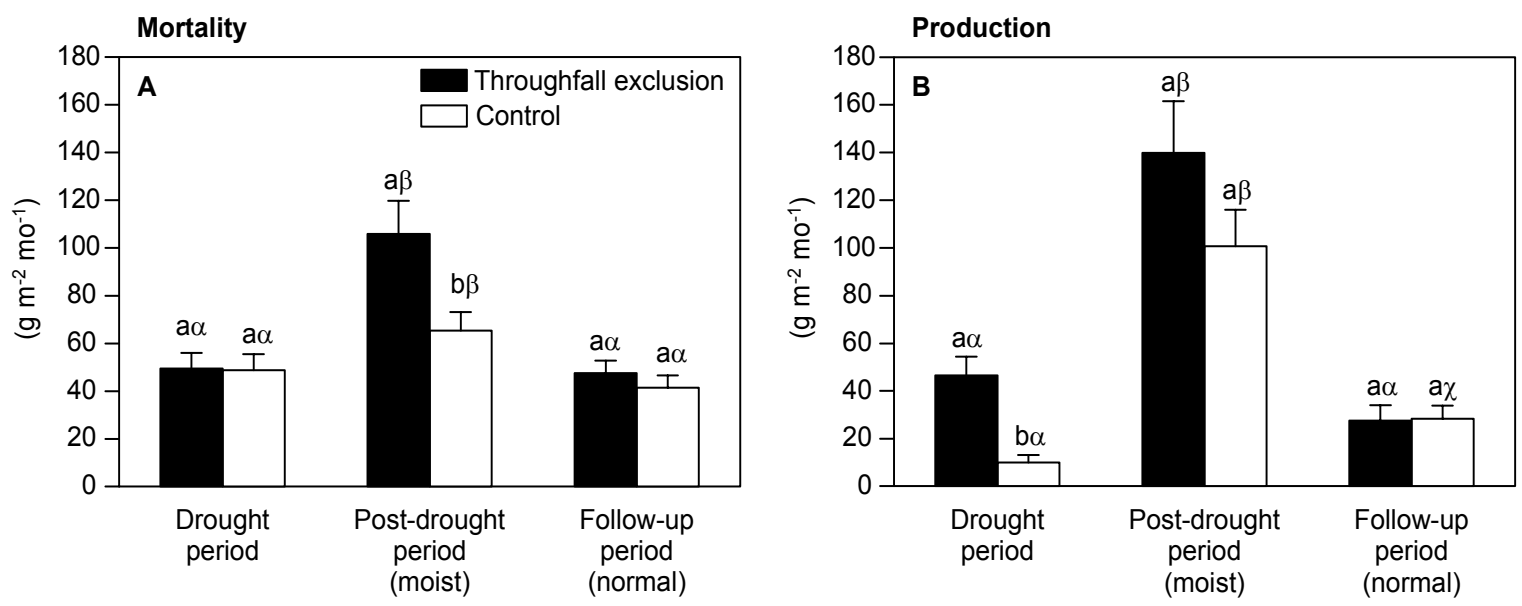

Figure 4: Fine root mortality (A) and production (B) at throughfall exclusion and control plots (mean $+\mathrm{SE}$ ) investigated by sequential soil coring during the drought period (June $22^{\text {nd }}$ to August $8^{\text {th }}$ ), post-drought period (August $8^{\text {th }}$ to September $22^{\text {nd }}$ ) and follow-up period (September $22^{\text {nd }}$ to December $\left.9^{\text {th }}\right)$ in 2006. Different Latin letters indicate significant differences $(p<0.05)$ between the treatments for a given measuring period, different Greek letters those between different periods for a given treatment.

\section{Changes in fine root length (minirhizotron data)}

Minirhizotron observations revealed that root length density in the organic layer was roughly similar in both throughfall exclusion and control plots throughout the entire study period (Figure 5). In the throughfall exclusion plots, fine root length remained almost constant during the drought period, while it increased in the same time by $25 \%$ in the 
control plots. In the post-drought period from the beginning of August until the end of September, this difference in fine root length increase between the two plot types disappeared.

In the upper mineral soil, fine root length density was approximately $70 \%$ lower than in the organic layer showing very similar values for throughfall exclusion and control plots on all sampling dates. In both depths, fine root length density increased continuously with time indicating that the root system in proximity of the minirhizotron tubes had not reached a steady state even though more than one year had passed since tube installation.

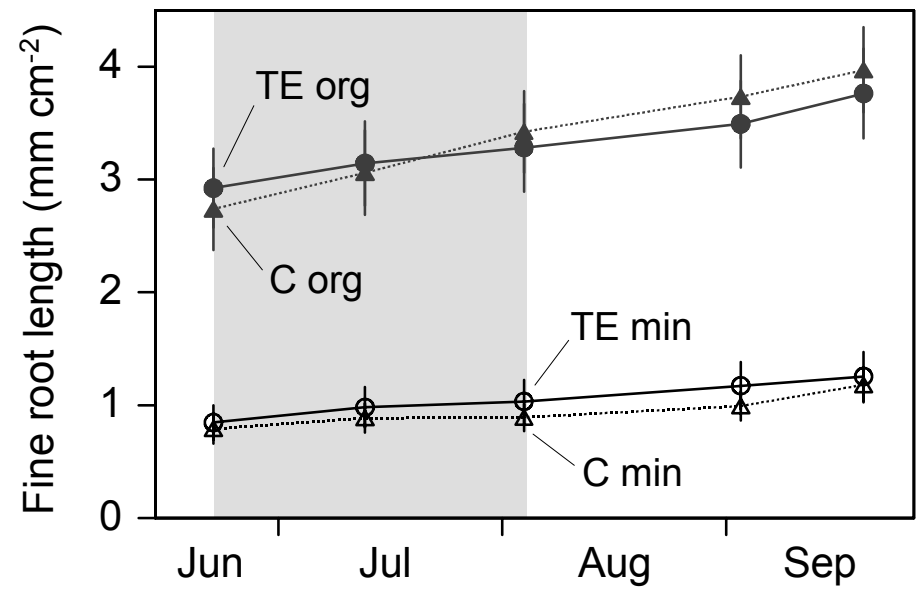

Figure 5: Fine root length density (mean $\pm \mathrm{SE}$ ) as observed by minirhizotron observations in the organic layer (org, filled) and the upper $25 \mathrm{~cm}$ of the mineral soil (min, open symbols) of the throughfall exclusion (TE, circles) and control (C, triangles) plots between June and September 2006. The period of experimental drought is marked in grey.

According to the minirhizotron data, a significant impact of experimental drought on fine root dynamics only existed in the organic layer, where the relative fine root loss was twice as high in the throughfall exclusion as in the control plots during the drought period (Figure 6). In contrast, relative fine root production tended to be higher in the organic layer of the control plots compared with the throughfall exclusion plots during the drought period and at the beginning of the post-drought period.

In the upper mineral soil, relative fine root loss was similar during the drought period but tended to be higher (by $160 \%$ ) in the control than in throughfall exclusion plots at the beginning of the post-drought period (Figure 6). Towards the end of the post-drought period, this trend was reversed and fine root loss tended to be higher (by about $110 \%$ ) in the throughfall exclusion than in the control plots. However, due to the large variation in our dataset for the mineral soil, these differences were not significant.

In both depths, fine root production was higher than fine root loss by a factor of more than 3 during the complete study. 

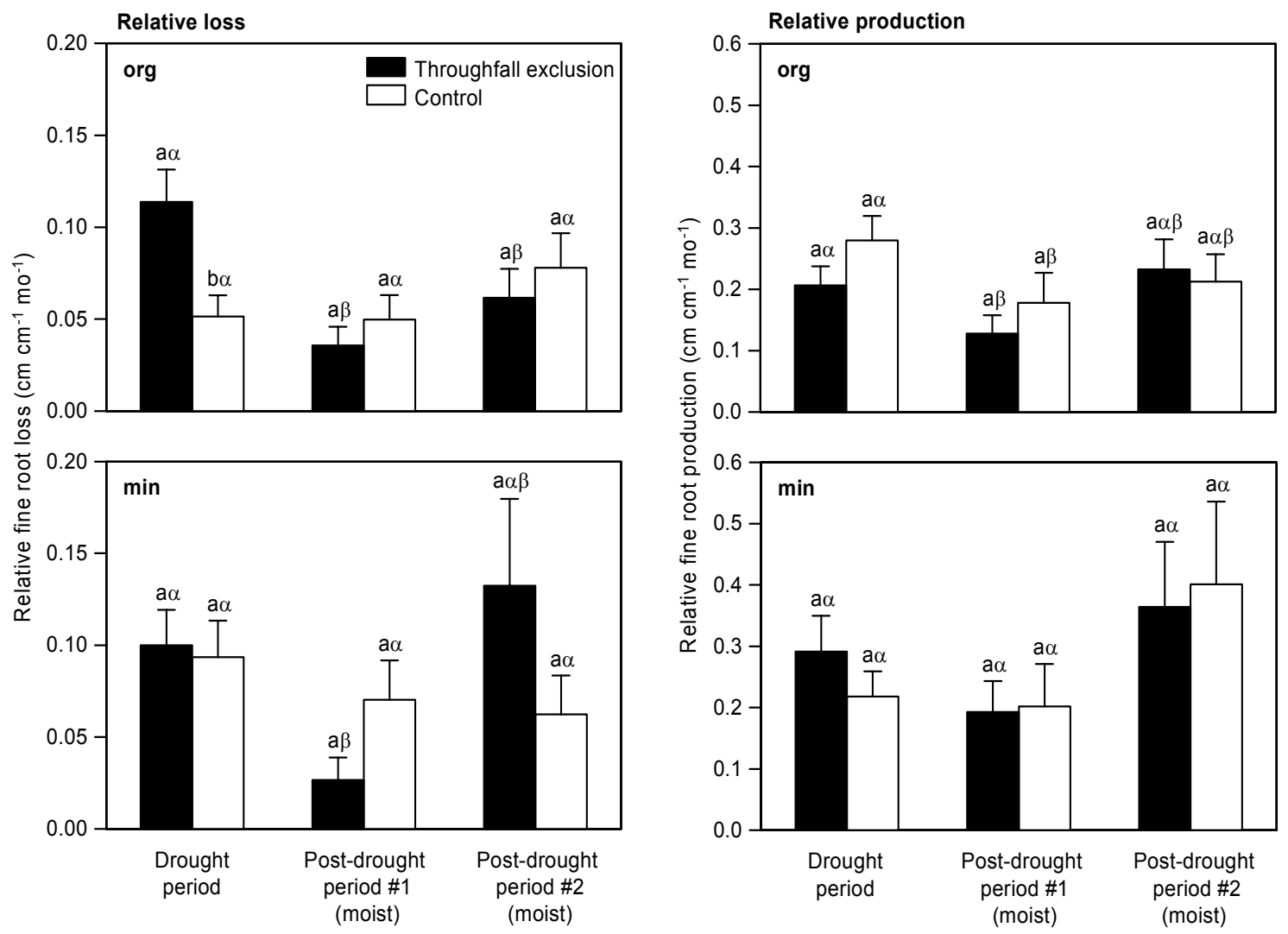

Figure 6: Relative loss (left) and production (right) of fine root length (mean $+\mathrm{SE}$ ) in the organic layer (org) and the upper $25 \mathrm{~cm}$ of the mineral soil (min) in the throughfall exclusion and control plots as calculated from minirhizotron data for the drought period (June $22^{\text {nd }}$ to August $8^{\text {th }}$ ), the post-drought period \#1 (August $8^{\text {th }}$ to September $5^{\text {th }}$ ) and the post-drought period \#2 (September $5^{\text {th }}$ to September $22^{\text {nd }}$ ). Relative loss and production were calculated from the length of disappearing fine roots (loss) or disappearing fine roots plus fine root length increment (production) during one period in relation to the standing stock of fine roots visible at the beginning of the period. Different Latin letters indicate significant differences $(p<0.05)$ between the treatments for one period, different Greek letters those between different periods for a given treatment. Note different scales for relative loss and production.

\section{Fine root turnover}

Monitoring fine root dynamics by sequential soil coring and minirhizotron image analysis allowed us to estimate fine root turnover in the organic layer of the studied spruce stand using two independent methods. Fine root turnover as calculated from the sequential coring data during the 6-wk-period of experimental drought plus the subsequent 6 weeks after rewetting was $0.45 \mathrm{mo}^{-1}$ in the throughfall exclusion plots and $0.41 \mathrm{mo}^{-1}$ in the control plots (data not shown). In contrast, turnover rates for the same period of time based on minirhizotron data were substantially lower in both throughfall exclusion and control plots (0.063 $\mathrm{mo}^{-1}$ and $0.054 \mathrm{mo}^{-1}$; data not shown). However, in accordance with 
the results from sequential coring, fine root turnover calculated from minirhizotron data tended to be higher in the throughfall exclusion plots compared with the control plots.

\section{Fine root decomposition}

Our calibration showed that $3.5 \mathrm{~g}$ wet root mass was equivalent to $0.86 \pm 0.02 \mathrm{~g}$ dry root mass (data not shown). Hence, we calculated a wet mass to dry mass conversion factor of 0.25 .

Recollecting the litterbags one month after rewetting showed that fine root decomposition during a period of 360 days was $26 \%$ and $21 \%$ in throughfall exclusion and control plots, respectively (Figure 7). Assuming that root mass loss was similar in treatment and control plots prior to the onset of the experiment, our litterbag experiment showed that experimental drought must have led to a significant reduction in fine root decomposition. Four months after rewetting, total fine root mass loss in the root litterbags had approached similar values in both plot types again indicating higher decomposition rates in the throughfall exclusion than in the control plots between September $10^{\text {th }}$ and December $9^{\text {th }}, 2006$.

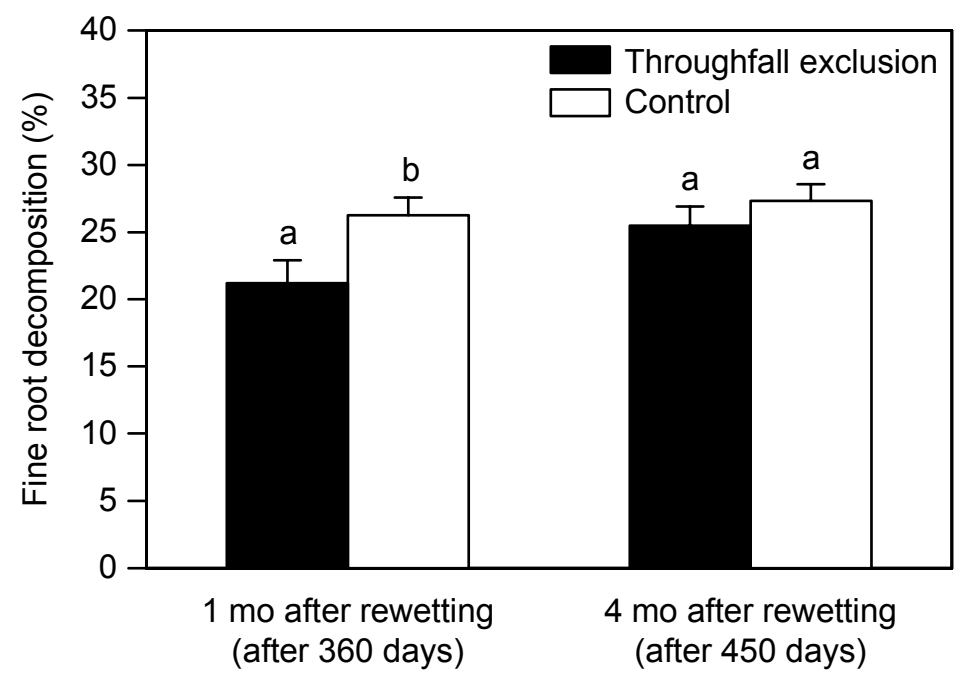

Figure 7: Fine root decomposition (mean $+\mathrm{SE}$ ) as observed in litterbags one month after experimental drought (after 360 days) and 4 months after rewetting (after 450 days) in the throughfall exclusion and control plots. Different Latin letters indicate significant differences ( $p$ $<0.05$ ) between the treatments for one date. 


\section{Discussion}

A comparison of results from existing studies on the effects of soil drought on fine roots is not conclusive. For example, fine root biomass of different tree species was either increased (de Visser et al., 1994; Parker and van Lear, 1996; Joslin and Wolfe, 1998), decreased (Blanck et al., 1995; Leuschner and Hertel, 2003; Meier and Leuschner, 2008) or similar (Santantonio and Herrman, 1985; Leuschner et al., 2001) with decreasing soil moisture. The observed impacts of varying water supply on fine root production, turnover and vertical displacement are not less diverse than those on biomass. However, the validity of these contrasting outcomes does not necessarily have to be questioned; different results might rather indicate that there is no simple and uniform response of fine roots to drought. The application of different methods represents an additional factor that could influence the results of fine root studies on reduced soil moisture.

In a literature review, Leuschner and Hertel (2003) found that fine root biomass was positively correlated to precipitation in coniferous but not in broad-leaved stands. They explain their finding with differences in drought tolerance of the respective tree species. In Sweden, Persson et al. (1995) recognized that fine roots of 28-year-old Norway spruce trees shifted to deeper mineral soil horizons as a consequence of experimentally induced drought. In contrast, Blanck et al. (1995) could not find such redistribution in a similar experiment with 60-year-old Norway spruce trees in Germany. These examples show that the impact of soil drought on fine root dynamics is not species-specific. Other factors such as soil conditions, climate and the degree of soil drought may strongly influence the response of fine root systems to reduced soil water contents as well.

The results from our inventory of fine root biomass up to $40 \mathrm{~cm}$ soil depth (382 and 439 $\mathrm{g} \mathrm{m}^{-2}$ ) fall in the middle range of values reported from 25 other stands of Norway spruce in temperate forests (69-640 $\mathrm{g} \mathrm{m}^{-2}$; Leuschner and Hertel, 2003). Leuschner and Hertel (2003) found that the fine root biomass in 22 Norway spruce stands was closely related to precipitation and increased at a rate of $38 \mathrm{~g}$ per $100 \mathrm{~mm}$ increase in precipitation. Our biomass data match very well with the root biomasses projected from the metaanalysis for Norway spruce stands with $1160 \mathrm{~mm}$ annual precipitation (about $450 \mathrm{~g} \mathrm{~m}^{-2}$ ). In the Fichtelgebirge spruce stand, fine root biomass density was by far highest in the organic layer and the upper mineral soil and decreased exponentially with depth. According to Gale and Grigal (1987), the vertical fine root distribution in this stand follows the characteristic patterns of root distribution of late-successional tree species like Norway spruce. Borken et al. (2007) and Schmid and Kazda (2002) found a similar 
vertical distribution of fine root biomass for mature trees of the same species on comparable sites. In general, fine root biomass distribution in the studied stand is typical for that of mature Norway spruce forests at montane elevation with poor nutrient availability.

In our experiment, sequential soil coring showed that mild drought, i.e. a decrease in soil moisture from 20 to 12 vol \% for a period of six weeks, led to a significant increase in both fine root biomass (by $48 \%$ ) and necromass (by $82 \%$ ) in the organic layer of the throughfall exclusion compared to the control plots. These differences in fine root mass remained constant even six weeks after the throughfall exclusion plots had been rewetted. We estimated that fine root mortality increased by $60 \mathrm{~g} \mathrm{~m}^{-2}$ as a consequence of the experimental drought. Despite the highly contrasting responses of tree roots to reduced water supply as reported above, increased fine root mortality is a common observation in most studies (e.g. Santantonio and Hermann, 1985; Mainiero and Kazda, 2006; Konopka et al., 2007; Meier and Leuschner, 2008). Enhanced mortality can either lead to a reduction in fine root standing stock as observed in saplings of European beech by Meier and Leuschner (2008), or it may be compensated by increased fine root production during or after drought (Santantonio and Herrmann, 1985). The direction of the response is probably dependent on the intensity of soil drought. If soil water matric potentials approach $-0.12 \mathrm{MPa}$, root growth typically tends to cease (Teskey and Hinckley, 1981; Kuhns et al., 1985; Torreano and Morris, 1998). In our case, the results from sequential soil coring showed that mild soil drought with soil water potential minima of $-600 \mathrm{hPa}$ stimulated fine root production of mature spruce trees, thereby compensating for enhanced mortality due to water shortage.

Trees that are responding to soil drought with enhanced rates of root shedding and the construction of new roots invest a considerable amount of energy in the process of root turnover. An alternative strategy is to maintain fine roots and to adapt to water shortage by reducing root respiration (Bryla et al., 1997; Eissenstat and Volder, 2005). However, because young roots are able to take up water more efficiently than older ones (Huang and Nobel, 1992), root shedding and regrowth might represent a more suitable adaptation of plants to reduced water supply (Caldwell and Richards, 1989). Eissenstat et al. (2000) propose that roots are only maintained under drought if the benefit : cost ratio in terms of water uptake and carbon expenditure is higher than under conditions of root shedding and construction of new roots. This was apparently not the case in our study.

We used both, sequential coring and the minirhizotron method, to investigate fine root dynamics in the densely rooted organic layer of the spruce stand because this approach 
combines the advantages of a quantification of root biomass and necromass with a nondestructive and direct root observation technique. In the absence of one standard method, the application of such a combined approach has been widely recommended (Nadelhoffer, 2000; Hertel and Leuschner, 2002; Hendricks et al., 2006). In our study, the minirhizotron results could only partly confirm the data of fine root dynamics obtained by sequential soil coring. On the one hand, the finding of enhanced fine root mortality in the organic layer due to experimental drought was in line with the results from sequential coring. On the other hand, the minirhizotron results did not show any increase in fine root growth in the treatment plots as a compensation for enhanced fine root loss. The root coring mass balance approach and the minirhizotron observations also yielded contrasting results in respect of the apparent timing of root growth and root death in the measuring period. From the coring data it appears that root death and root re-growth in the organic layer happened mostly in the 6-wk period after rewetting. However, it must be kept in mind that sequential coring will only reflect the outcome of growth and death events that have happened in the period prior to sampling. Indeed, the minirhizotron data indicate that a relatively high fine root death must have happened during and not after the drought period. Thus, direct observation points to a rapid response in root dynamics indicating that the apparent delay in the root response in the coring data is an inherent consequence of this approach. While we applied the sequential coring method only in the organic layer, minirhizotron observations included the upper ca. $25 \mathrm{~cm}$ of the mineral soil. In this layer, however, fine root density was much lower and fine root dynamics were not substantially influenced by induced drought.

Nowadays, the minirhizotron technique is suggested to provide more realistic results on fine root dynamics than sequential coring (Publicover and Vogt, 1993; Majdi, 1996; Hendricks et al., 2006; Majdi et al., 2007). In our study, however, interpreting the results from minirhizotron observations was complicated. Fine root production was higher than fine root mortality by a factor of about 3 throughout the complete study indicating that the root system in proximity to the minirhizotron tubes had not reached equilibrium until more than one year after tube installation. As a consequence, our minirhizotron data did not only reflect actual root dynamics but also compensation growth after soil disturbance (Joslin and Wolfe, 1999). Since our results from the sequential coring approach are based on a substantial number of samples (three replicate plots with each 20 cores per sampling date), they should provide a reliable picture of fine root dynamics in the organic layer of the spruce stand. 
The mean carbon and nitrogen content of the fine root biomass in the studied spruce stand was 46 and $1.9 \%$, respectively. Assuming that experimental drought for a period of six weeks caused an increase in fine root mortality in the organic layer by $60 \mathrm{~g} \mathrm{~m}^{-2}$, this leads to an additional input of $28 \mathrm{~g} \mathrm{~m}^{-2}$ of carbon and $1.1 \mathrm{~g} \mathrm{~m}^{-2}$ of nitrogen to the particulate organic matter fraction in the soil. Because the frequencies of summer drought periods are predicted to increase in temperate regions of the northern hemisphere with climate change (Hulme and Sheard, 1999; Johns et al., 2001), the results of our experiment suggest that considerable amounts of additional carbon and nitrogen fluxes might occur in mature Norway spruce forests at montane elevation in the future.

Predictions about the consequences of our findings for long-term carbon sequestration in the soil are premature because exact data on root necromass decomposition are not yet available. Our root litterbag experiment, however, indicates that drought leads to a decrease in root necromass decomposition rate, thus delaying the transfer of carbon and nutrients from dead roots to the soil solution. Therefore, it is not clear whether drought actually increases the root-derived carbon fluxes to the soil due to increased fine root turnover, or whether it mainly leads to an increase in the root necromass pool, which is only mobilized in periods of favorable soil moisture and temperature conditions. Moreover, increased fine root turnover due to drought may result in a reduction of aboveground productivity of spruce, which should reduce fine root growth over long time spans as well. Thus, future research has to consider aboveground carbon fluxes as well since drought-induced compensatory root production is expected to consume considerable amounts of mobile carbohydrates.

\section{Acknowledgements}

We thank Irmgard Gerstmann for her help during the fine root analyses. Gerhard Müller, Uwe Hell and Andreas Kolb from Bayreuth Center of Ecology and Environmental Research (BayCEER) provided technical assistance during installation and operation of the research plots. The DFG (Deutsche Forschungsgemeinschaft) funded our project in the framework of the Research Group "Bodenprozesse" FOR 562. 


\section{References}

Aber, J.D., Melillo, J.M., Nadelhoffer, K.J., McClaugherty, C.A., Pastor, J. 1985. Fine root turnover in forest ecosystems in relation to quantity and form of nitrogen availability: a comparison of two methods. Oecologia 66, 317-321.

Aerts, R., Bakker, C., De Caluwe, H. 1992. Root turnover as determinant of the cycling of $C, N$, and $P$ in a dry heathland ecosystem. Biogeochemistry 15, 175-190.

Alavi, G. 1996. Radial stem growth of Picea abies in relation to spatial variation in soil moisture conditions. Scandinavian Journal of Forest Research 11, 209-219.

Blanck, K., Lamersdorf, N., Dohrenbusch, A., Murach, D. 1995. Response of a Norway spruce forest ecosystem to drought/rewetting experiments at Solling, Germany. Water, Air, \& Soil Pollution 85, 1251-1256.

Bloomfield, J., Vogt, K., Wargo, P.M., 1996. Tree root turnover and senescence. In: Waisel, Y., Eshel, A., Kafkafi, U. (Eds.), Plant roots: the hidden half. Dekker, New York, pp. 363-381.

Borken, W., Kossmann, G., Matzner, E. 2007. Biomass, morphology and nutrient contents of fine roots in four Norway spruce stands. Plant and Soil 292, 79-93.

Bryla, D.R., Bouma, T.J., Eissenstat, D.M. 1997. Root respiration in citrus acclimates to temperature and slows during drought. Plant, Cell \& Environment 20, 1411-1420.

Caldwell, M.M., Richards, J.H., 1989. Competing root systems: morphology and models of absorption. In: Givnish, T.J. (Ed.), On the Economy of Plant Form and Function. Cambridge Univ. Press, Cambridge, pp. 251-273.

Christensen, J.H., Christensen, O.B. 2003. Climate modelling: Severe summertime flooding in Europe. Nature 421, 805-806.

Davies, W.J., Bacon, M.A., 2003. Adaptation of roots to drought. In De Kroon, H., Visser, E.J.W. (Eds.), Root Ecology. Ecological Studies 168. Springer Verlag, Berlin, pp. 173-192.

De Visser, P.H.B., Beier, C., Rasmussen, L., Kreutzer, K., Steinberg, N., Bredemeier, M., Blanck, K., Farrell, E.P., Cummins, T. 1994. Biological response of five forest ecosystems in the EXMAN project to input changes of water, nutrients and atmospheric loads. Forest Ecology and Management 68, 15-29.

Eissenstat, D.M., Wells, C.E., Yanai, R.R., Whitbeck, J.L. 2000. Building roots in a changing environment: implications for root longevity. New Phytologist 147, 33-42.

Eissenstat, D.M., Volder, A., 2005. The efficiency of nutrient acquisition over the life of a root. In: BassiriRad, H. (Ed.), Nutrient Acquisition by Plants: An Ecological Perspective. Ecological Studies 191. New York, Springer-Verlag, pp.185-220.

Fairley, R.I., Alexander, I.J., 1985. Methods of calculation fine root production in forests. In: Fitter, A.H., Atkinson, D., Read, D.J. (Eds.), Ecological interactions in soil: plants, microbes and animals. Blackwell Scientific Publications Oxford, U.K., pp. 37-42. 
Foken, T. 2003. Lufthygienisch-Bioklimatische Kennzeichnung des oberen Egertales. Bayreuther Forum Ökologie 100, 1-118.

Gale, M.R., Grigal, D.F. 1987. Vertical root distributions of northern tree species in relation to successional status. Canadian Journal of Forest Research 17, 829-834.

Gill, R.A., Jackson, R.B. 2000. Global patterns of root turnover for terrestrial ecosystems. New Phytologist 147, 13-31.

Guo, L.B., Halliday, M.J., Siakimotu, S.J.M., Gifford, R.M. 2005. Fine root production and litter input: its effect on soil carbon. Plant and Soil 272, 1-10.

Hendrick, R.L., Pregitzer, K.S. 1992. The demography of fine roots in a northern hardwood forest. Ecology 73, 1094-1104.

Hendrick, R.L., Pregitzer, K.S. 1993. The dynamics of fine root length, biomass, and nitrogen content in two northern hardwood ecosystems. Canadian Journal of Forest Research 23, 2507-2520.

Hendricks, J.J., Hendrick, R.L., Wilson, C.A., Mitchell, R.J., Pecot, S.D., Guo, D.L. 2006. Assessing the patterns and controls of fine root dynamics: an empirical test and methodological review. Journal of Ecology 94, 40-57.

Hentschel, K., Borken, W., Matzner, E. 2007. Leaching losses of inorganic N and DOC following repeated drying and rewetting of a spruce forest soil. Plant and Soil 300, 2134.

Hertel, D., Leuschner, Ch. 2002. A comparison of four different fine root production estimates with ecosystem carbon balance data in a Fagus-Quercus mixed forest. Plant and Soil 239, 237-251.

Hertel, D., Leuschner, Ch. 2006. The in situ root chamber: A novel tool for the experimental analysis of root competition in forest soils. Pedobiologia 50, 217-224.

Huang, B., Nobel, P.S. 1993. Hydraulic conductivity and anatomy along lateral roots of cacti: changes with soil-water status. New Phytologist 123, 499-507.

Hulme, M., Sheard, N., 1999. Climate Change Scenarios for Germany. Climate Research Unit, Norwich, UK.

IPCC 2007. Climate Change 2007: the physical basis. Summary for policymakers. Contribution of working group I to the fourth assessment report of the Intergovernmental Panel on Climate Change.

IUSS Working Group WRB 2006. World reference base for soil resources 2006. $2^{\text {nd }}$ edition. World Soil Resources Report No. 103, FAO, Rome.

Jackson, R.B., Mooney, H.A., Schulze, E.D. 1997. A global budget for fine root biomass, surface area, and nutrient contents. Proceedings of the National Academy of Sciences, USA 94, 7362-7366. 
Johns, T.C., Gregory, J.M., Ingram, W.J., Johnson, C.E., Jones, A., Lowe, J.A., Mitchell, J.F.B., Roberts, D.L., Sexton, D.M.H., Stevenson, D.S., Tett, S.F.B., Woodage, M.J., 2001. Anthropogenic climate change for 1860 to 2100 simulated with the HadCM3 model under updated emission scenarios. Dept. of Meteorology, University of Edinburgh, King's Buildings.

Joslin, J.D., Wolfe, M.H. 1998. Impacts of water input manipulations on fine root production and mortality in a mature hardwood forest. Plant and Soil 204, 165-174.

Joslin, J.D., Wolfe, M.H. 1999. Disturbances during minirhizotron installation can affect root observation data. Soil Science Society of America Journal 63, 218-221.

Joslin, J.D., Wolfe, M.H., 2003. Fine-root growth response. In: Hanson, P.J., Wullschleger, S.D. (Eds.) North American Temperate Deciduous Forest Response to Changing Precipitation Regimes. Ecological Studies 166. Springer, New York, pp. 274302.

Kavanaugh, T., Kellman, M. 1992. Seasonal pattern of fine root proliferation in a tropical dry forest. Biotropica 24, 157-165.

Konopka, B., Noguchi, K., Sakata, T., Takahashi, M., Konopkova, Z. 2007. Effects of simulated drought stress on the fine roots of Japanese cedar (Cryptomeria japonica) in a plantation forest on the Kanto Plain, eastern Japan. Journal of Forest Research 12, 143-151.

Kuhns, M.R., Garrett, H.E., Teskey, R.O., Hinckley, T.M. 1985. Root growth of black walnut trees related to soil temperature, soil water potential, and leaf water potential. Forest Science 31, 617-629.

Kummerow, J., Castellanos, J., Mass, M., Larigauderie, A. 1990. Production of fine roots and the seasonality of their growth in a Mexican deciduous dry forest. Vegetatio $90,73-80$.

Lauenroth, W.K., Gill, R., 2003. Turnover of root systems. In: de Kroon, H., Visser, E.J.W. (Eds.). Root ecology. Ecological Studies 168. Springer, Berlin, pp. 61-90.

Leuschner, Ch., Backes, K., Hertel, D., Schipka, F., Schmitt, U., Terborg, O., Runge, M. 2001. Drought responses at leaf, stem and fine root levels of competitive Fagus sylvatica L. and Quercus petraea (Matt.) Liebl. trees in dry and wet years. Forest Ecology and Management 149, 33-46.

Leuschner, Ch., Hertel, D. 2003. Fine root biomass of temperate forests in relation to soil acidity and fertility, climate, age and species. Ecology 64, 405-438.

Mainiero, R., Kazda, M. 2006. Depth-related fine root dynamics of Fagus sylvatica during exceptional drought. Forest Ecology and Management 237, 135-142.

Majdi, H. 1996. Root sampling methods - applications and limitations of the minirhizotron technique. Plant and Soil 185, 255-258.

Majdi, H., Damm, E., Nylund, J.-E. 2000. Longevity of mycorrhizal roots depends on branching order and nutrient availability. New Phytologist 150, 195-2002. 
Majdi, H., Nylund, J.E., Agren, G.I. 2007. Root respiration data and minirhizotron observations conflict with root turnover estimates from sequential soil coring. Scandinavian Journal of Forest Research 22, 299-303.

McClaugherty, C.A., Aber, J.D., Melillo, J.M. 1982. The role of fine roots in the organic matter and nitrogen budgets of two forested ecosystems. Ecology 63, 1481-1490.

Meier, I.C., Leuschner, Ch. 2008. Genotypic variation and phenotypic plasticity in the drought response of fine roots of European beech. Tree Physiology 28, 297-309.

Nadelhoffer, K.J. 2000. The potential effects of nitrogen deposition on fine-root production in forest ecosystems. New Phytologist 147, 131-139.

Parker, M.M., Van Lear, D.H. 1996. Soil heterogeneity and root distribution of mature loblolly pine stands in Piedmont soils. Soil Science Society of America Journal 60, 1920-1925.

Persson, H. 1978. Root dynamics in a young Scots pine stand in Central Sweden. Oikos 30, 508-519.

Persson, H., von Fircks, Y., Majdi, H., Nilsson, L.O. 1995. Root distribution in a Norway spruce (Picea abies (L.) Karst.) stand subjected to drought and ammonium-sulphate application. Plant and Soil 168/169, 161-165.

Powell, S.W., Day, F.P. 1991. Root production in four communities in the Great Dismal Swamp. American Journal of Botany 78, 288-297.

Publicover, D.A., Vogt, K.A. 1993. A comparison of methods for estimating fine-root production with respect to sources of error. Canadian Journal of Forest Research, 23 1179-1186.

Rasse, D.P., Rumpel, C., Dignac, M.F. 2005. Is soil carbon mostly root carbon? Mechanisms for a specific stabilisation. Plant and Soil 269, 341-356.

Rowell, D.P., Jones, R.G. 2006. Causes and uncertainty of future summer drying over Europe. Climate Dynamics 27, 281-299.

Santantonio, D., Hermann, R.K. 1985. Standing crop, production, and turnover of fine roots on dry, moderate, and wet sites of mature Douglas fir in Western Oregon. Annales des Sciences Forestieres 42, 113-142.

Schmid, I., Kazda, M. 2002. Root distribution of Norway spruce in monospecific and mixed stands on different soils. Forest Ecology and Management 159, 37-47.

Sharp, R.E., Davies, W.J. 1979. Solute regulation and growth by roots and shoots of water-stressed maize plants. Planta 147, 43-49.

Spiecker, H. 1995. Growth dynamics in a changing environment: Long-term observations. Plant and Soil 168/169, 555-561.

Srivastava, S.K., Singh, K.P., Upadhyay, R.S. 1986. Fine root growth dynamics in teak (Tectona grandis Linn. F.). Canadian Journal of Forest Research 16, 1360-1364. 
Teskey, R.O., Hinckley, T.M. 1981. Influence of temperature and water potential on root growth of white oak. Physiologia Plantarum 52, 363-369.

Tingey, D.T., Phillips, D.L., Johnson, M.G. 2000. Research review - Elevated $\mathrm{CO}_{2}$ and conifer roots: effects on growth, life span and turnover. New Phytologist 147, 87-103.

Torreano, S.J., Morris, L.A. 1998. Loblolly pine root growth and distribution under water stress. Soil Science Society of America Journal 62, 818-827. 


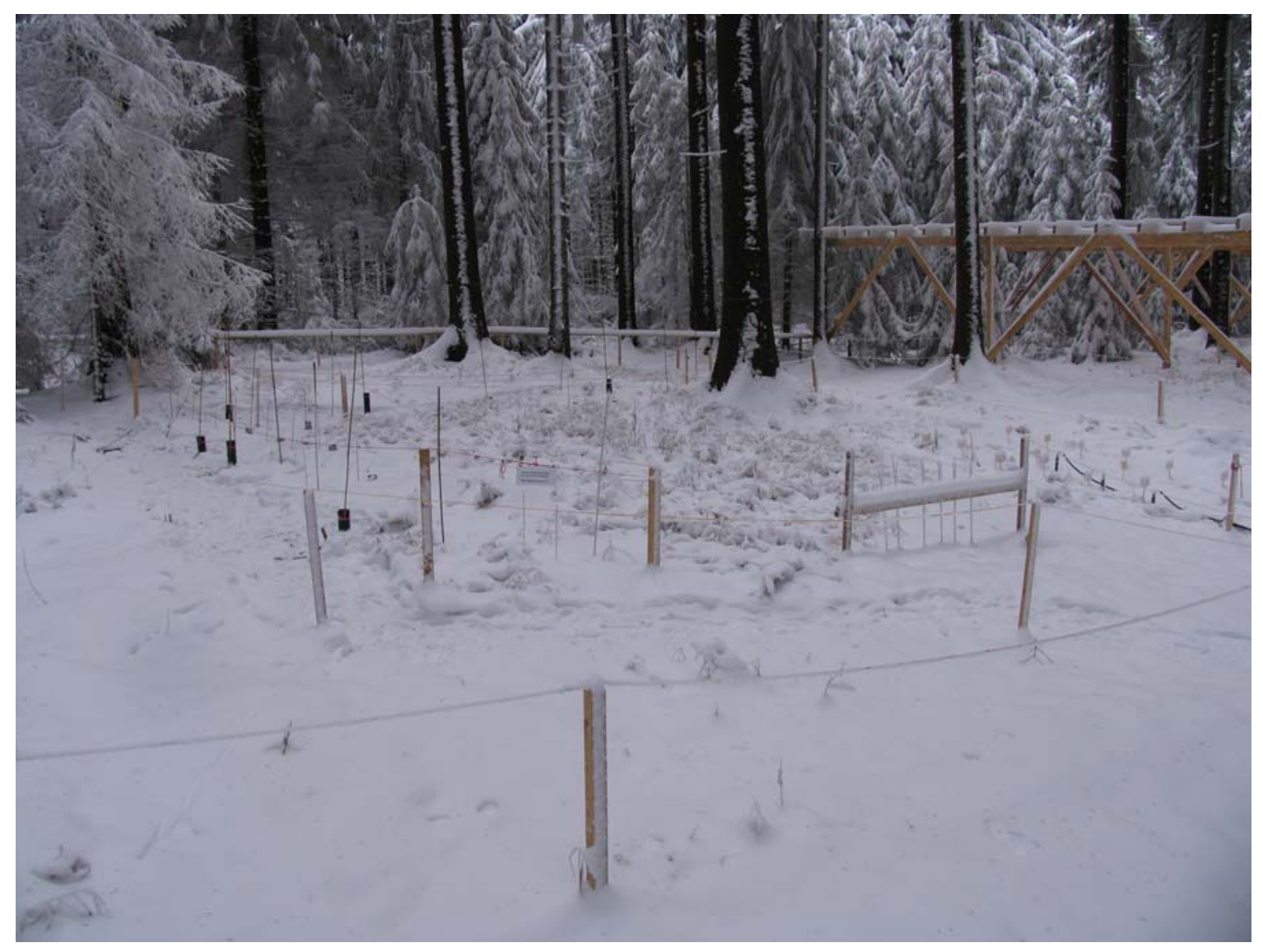




\title{
Chapter 3
}

\section{Effects of experimental soil frost on the fine root system of mature Norway spruce}

\author{
Dirk Gaul, Dietrich Hertel and Christoph Leuschner
}

Journal of Plant Nutrition and Soil Science (accepted) 


\section{Summary}

Soil frost events may influence the dynamics of fine roots and therefore affect rootderived carbon fluxes to the soil. We studied the impact of soil frost on the fine root dynamics of Norway spruce (Picea abies (L.) Karst.) by a replicated snow removal experiment in a mature forest in Southeast Germany. Snow removal in the three treatment plots reduced soil temperature significantly with minima below $-5.5^{\circ} \mathrm{C}$ in the organic layer while the snow-covered control plots never reached temperatures below the freezing point. Sequential soil coring in the organic layer at the beginning and at the end of the soil frost period as well as after thawing revealed that the soil frost treatment increased fine root mortality by $29 \%$. However, enhanced fine root production in the snow removal plots nearly compensated for the fine root losses caused by low temperatures. These findings were confirmed by minirhizotron observations in the organic layer and the upper $25 \mathrm{~cm}$ of the mineral soil showing that relative fine root loss was by far higher in the snow removal plots than in the control plots. Compensatory fine root production in the snow removal plots exceeded fine root production in the control plots during a period of 8 weeks after the soil frost application by $39 \%$ in the organic layer while it was similar in both plot types in the mineral soil. Sequential coring and minirhizotron observations led to substantially different fine root longevity estimates for the soil frost period. However, in both cases, the snow removal treatment was characterized by a significant reduction in root longevity indicating a faster fine root turnover. As a consequence, experimental soil frost enhanced the carbon input to the organic soil layer via root death at our study site by about $42 \mathrm{~g} \mathrm{~m}^{-2}$ and stimulated the carbon investment towards the root system of the spruce trees due to a higher sink activity.

Key words: fine root biomass, fine root longevity, minirhizotron, root necromass, sequential coring, snow removal 


\section{Introduction}

Fine root dynamics represent an important component of ecosystem carbon cycling (Schlesinger, 1997). Although the roots $<2 \mathrm{~mm}$ in diameter may contribute less than 2 $\%$ of tree biomass in mature forests, fine root growth can consume up to $50 \%$ or more of the carbon fixed by the canopy (Keyes and Grier, 1981; Fogel and Hunt, 1983). Assuming that mean fine root lifespan is one year, Jackson et al. (1997) estimated that fine roots consume about $30 \%$ of the global net primary production. Together with above-ground litter fall, root production provides the primary input of organic carbon to soils. Thus, soil organic matter and root dynamics are intimately linked. However, our understanding of below-ground $C$ transfer processes is still limited especially with respect to the dependency of root dynamics on abiotic stress. Together with the process of root exudation and the exchange processes between root and mycorrhizal fungi, fine root production and mortality rank among the least known processes in the rhizosphere (Eissenstat and Yanai, 1997; Vogt et al., 1998). This knowledge is urgently needed because carbon storage and fluxes are of major importance regarding the effects of increasing drought intensities, changed winter precipitation regimes, eutrophication, soil acidification, and other environmental changes taking place or expected to do so in the near future (Davidson et al., 2002; Guo et al., 2005; Lal, 2005). Changes in fine root dynamics would affect either directly or indirectly plant growth, tree vigor and carbon sequestration. According to the predictions of climatologists, climate warming may lead to increases in winter temperature and stronger and more frequent summer droughts in many regions of Central Europe (Hulme and Sheard, 1999; Johns et al., 2001; Christensen and Christensen, 2003). However, decreasing snow cover in winter may result in stronger soil frost even though average winter air temperatures are increasing. Tierney et al. (2001) found that fine root mortality and turnover were accelerated by experimentally enhanced soil frost in a temperate deciduous forest of North America.

Norway spruce is one of the economically most important tree species in Central Europe. Numerous studies have reported on the response of this conifer to different climatic and soil chemical stressors. However, most of these investigations were focused on the above-ground compartments of spruce trees or stands (e.g. Blanck et al., 1995; Spiecker, 1995; Alavi, 1996; Makinen at al., 2000), while our information on the fine root system of Norway spruce is less complete. The majority of studies on the fine root system of Picea abies investigated effects of aluminum, protons, or water and nutrient availabilities on root biomass and vitality (e.g. Clemensson-Lindell and Persson, 
1995; Persson et al.,1995; Hogberg et al., 1998; Ostonen et al., 1999; Jentschke et al., 2001; Majdi, 2001; Persson and Ahlström, 2002; Godbold et al., 2003). In contrast, studies on the effect of soil frost on the fine root system of Norway spruce are scarce. In particular, replicated field experiments investigating the effect of winter frost on fine root growth and mortality in mature stands are missing.

We used a replicated snow removal experiment in a mature Norway spruce stand in SE Germany to study the effects of experimentally induced soil frost on fine root dynamics. Two independent methods (sequential coring and the minirhizotron technique) were applied to monitor fine root dynamics over time. While sequential coring provides precise quantifications of fine root biomass and necromass, root observation through minirhizotron tubes is a non-destructive technique that allows for direct measurement of fine root production and mortality.

The hypotheses of this study were that (i) soil frost increases fine root mortality leading to a higher input of root-born organic matter into the soil, (ii) soil frost induced fine root mortality is compensated by higher rates of fine root production, thereby increasing the carbon sink strength of the root system due to a higher fine root turnover.

\section{Materials and methods}

Study site and experimental set-up

The study was conducted in a pure Norway spruce (Picea abies (L.) Karst.) forest at montane elevation ( $870 \mathrm{~m}$ a.s.I.) in the Fichtelgebirge, SE Germany ( $\left.50^{\circ} 08^{\prime} \mathrm{N}, 11^{\circ} 52^{\prime} \mathrm{E}\right)$. Mean annual air temperature is about $5.3^{\circ} \mathrm{C}$ (Foken, 2003) with a cold continental winter climate. Average annual precipitation is approximately $1160 \mathrm{~mm}$.

The forest consists mainly of 140-yr-old spruce trees with a dense canopy and a mean tree height of about $30 \mathrm{~m}$. The above-ground forest structure of the research plots is characterized in Table 1 . The patchy ground vegetation includes mainly the two grass species Deschampsia flexuosa (L.) and Calamagrostis villosa (Chaix). 
Table 1: Characterization of the above-ground structure for the six research plots at the study site (data from Borken et al., unpublished).

\begin{tabular}{lcccccc}
\hline & \multicolumn{3}{c}{ Snow removal } & \multicolumn{3}{c}{ Control } \\
& SR1 & SR2 & SR3 & C1 & C2 & C3 \\
\hline Plot size $\left(\mathrm{m}^{2}\right)$ & 312 & 389 & 420 & 308 & 342 & 392 \\
Number of trees & 12 & 12 & 16 & 6 & 12 & 17 \\
Stem density $\left(\mathrm{ha}^{-1}\right)$ & 385 & 308 & 381 & 195 & 351 & 433 \\
Basal area $\left(\mathrm{m}^{2} \mathrm{ha}^{-1}\right)$ & 45 & 41 & 54 & 30 & 45 & 58 \\
\hline
\end{tabular}

The soil developed from granite and is classified as Haplic Podsol (IUSS, 2006). The texture of the acidic soil is sandy to loamy with $\mathrm{pH}$-values $\left(\mathrm{H}_{2} \mathrm{O}\right)$ ranging between 4.0 in the Oa horizon and 4.5 in the Bw horizon (Hentschel et al., in press). The thickness of the organic layer (Oi, Oe, Oa) ranges between 5 and $17 \mathrm{~cm}$.

With the aim of investigating the effects of enhanced soil frost on fine root dynamics, 6 research plots of approximately $20 \mathrm{~m}$ x $20 \mathrm{~m}$ were selected, of which three were chosen for snow removal treatment and three as a control. In every plot, a transect of $13 \mathrm{~m}$ length and $1 \mathrm{~m}$ width was demarcated for the fine root studies. Intensive soil frost was induced by manual snow removal between December 2005 and February 2006 for a period of two months. In order to avoid organic layer material to be removed by snow shoveling activities, the soil was covered by polyvinyl nets during winter 2005/06. Additionally, the root study transects were covered by roofs of about $50 \mathrm{~cm}$ height to prevent the root study installations (e.g. minirhizotron tubes and location markers) from being damaged. After the end of the snow removal treatment in February, snow was allowed to accumulate at all plots until it melted in spring. Soil temperature in the organic layer was monitored by five temperature data loggers in each plot (DS 1921 Thermochron iButtons, Fa. Dallas Semiconductor, USA) during the whole study period.

\section{Fine root inventory}

In summer 2005, an inventory of fine root biomass and necromass ( $<2 \mathrm{~mm}$ ) was carried out in all six study plots to test the comparability of the sites in terms of root density. In each transect per plot, 12 sampling locations were randomly selected to examine the standing stock of fine root biomass and fine root necromass in the organic layer and the upper $40 \mathrm{~cm}$ of the mineral soil. On three dates (June $30^{\text {th }}$, August $11^{\text {th }}$ and September $\left.19^{\text {th }}\right)$, we took samples from 12 locations each per plot type with a soil 
corer (3.5 $\mathrm{cm}$ in diameter). This approach of repeated sampling did not only allow us to compare fine root density between snow removal and control plots for one certain date but also for a period of three months. The samples were transferred to plastic bags and transported to the laboratory in Göttingen, where they were stored at $4{ }^{\circ} \mathrm{C}$ and processed within five weeks. In the lab, the samples were cleaned from soil residues using a sieve with a mesh size of $0.25 \mathrm{~mm}$. Large root particles (>1 cm length) were picked from the sieve and placed under a stereomicroscope, where they were separated into living (biomass) and dead (necromass) according to the criteria defined by Persson (1978) and Leuschner et al. (2001). The fine root mass obtained by this procedure includes the major part of the biomass, but misses large amounts of dead, partly decayed rootlets (Bauhus and Bartsch, 1996; Hertel, 1999). In order to cover these smaller root particles as well, we examined half of the samples additionally applying a more detailed procedure. This complementary method of root analysis was introduced by van Praag et al. (1988) and modified by Hertel (1999); it results in much higher fine root necromass values than obtained by conventional analyses. Finally, living and dead root mass was dried at $70{ }^{\circ} \mathrm{C}$ for $48 \mathrm{~h}$, weighed, and the data expressed as fine root abundance $\left(\mathrm{g} \mathrm{m}^{-2}\right)$.

\section{Fine root dynamics}

In each of the six plots (snow removal and control), 20 sampling locations per transect were randomly selected to monitor changes in fine root mass over time using the sequential coring method (Persson, 1978; McClaugherty et al., 1982). Each 20 cores of the organic layer were taken at the beginning of experimental soil frost (December $23^{\text {rd }}$, 2005), at the end of experimental soil frost (February 23 ${ }^{\text {rd }}, 2006$ ) and after thawing (June $5^{\text {th }}, 2006$ ) in the same way as described above. Based on the sequential coring data, fine root production and fine root mortality between two subsequent sampling dates were calculated using the balancing transfer method (Fairley and Alexander, 1985). Fine root turnover was calculated as the ratio of total fine root mortality (frost plus follow-up period) to mean standing fine root biomass (Nadelhoffer, 2000). Fine root longevity, the inverse of fine root turnover, is based on the mortality rate during the soil frost period extrapolated to a full year.

In addition to the sequential coring method, we investigated fine root dynamics in the organic layer and the upper $25 \mathrm{~cm}$ of the mineral soil by in situ observation with minirhizotrons. Eight transparent plastic tubes $(67 \mathrm{~cm}$ long $\times 7.0 \mathrm{~cm}$ in diameter $)$ per plot were installed vertically in the soil in June 2005, i.e. six months prior to the 
beginning of the snow removal treatment. The tubes were sealed at the bottom and closed by removable plastic caps at the top to prevent their filling with water. The aboveground parts of the tubes were covered with tape to avoid the penetration of sunlight into the minirhizotrons. Fine root images were collected approximately every four weeks between December 2005 and June 2006 using a scanner system (Cl-600 Root Growth Monitoring System, FA. CID, USA). Color images of 200 dpi for the entire tube surface until $40 \mathrm{~cm}$ soil depth were taken.

The images were analyzed using the software WinRhizo Tron (FA. Régent, Canada). Due to uncertainties in distinguishing living from dead roots on the images, we classified roots as either present or gone. By comparing visible and disappeared fine root length of current and previous images, root production and root loss were calculated per month (Majdi, 1996). Data on relative production and loss were obtained by relating recent root production or loss to the standing fine root length of the previous date (cm/cm/mo; Hendricks et al., 2006). By extrapolating the results of relative root loss (in percent of standing stock) to a full year, fine root longevity was estimated on an annual basis (Nadelhoffer, 2000).

\section{Statistical analysis}

All data sets on fine roots were not normally distributed according to the Shapiro-Wilk test. Even after log or root transformation most data sets were skewed. Therefore, nonparametric Mann-Whitney two-sample tests (U-tests) with a $5 \%$ rejection level were used to test for significant differences in fine root standing stock, production, mortality and longevity between treatment and control and different dates and methods. The calculations were conducted with the software package SAS version 8.2 (SAS Institute, Cary, NC, USA). 


\section{Results}

Structure of the fine root system of the six plots

Soil coring about six months prior to experimental soil frost did not reveal any significant differences in fine root biomass and necromass distribution between snow removal and control plots (data not shown). Fine root biomass was very similar for both plot types in the organic layer but tended to be higher by about $17 \%$ in the mineral soil of the control plots compared to the snow removal plots. Hence, the profile totals of fine root biomass tended to be higher in the control plots $\left(440 \mathrm{~g} \mathrm{~m}^{-2}\right)$ than in the snow removal plots (383 $\mathrm{g} \mathrm{m}^{-2}$ ). The fine root necromass was similar for both plot types with profile totals of 500 and $550 \mathrm{~g} \mathrm{~m}^{-2}$ in the snow removal and control plots (data not shown). As for fine root biomass, the fine root necromass was nearly identical in the organic layer of the plots, but tended to be higher by ca. $16 \%$ in the mineral soil of the control plots.

In the soil profiles of both treatments, the fine root density decreased exponentially from the organic layer and the upper mineral soil to the deeper mineral soil. This is reflected by the relatively low $\beta$ value (0.94) of the fine root biomass depth function $y=1-\beta^{d}$ according to Gale and Grigal (1987) (where y represents the cumulative portion of the standing fine root biomass in the respective soil depth d) (Figure 1).

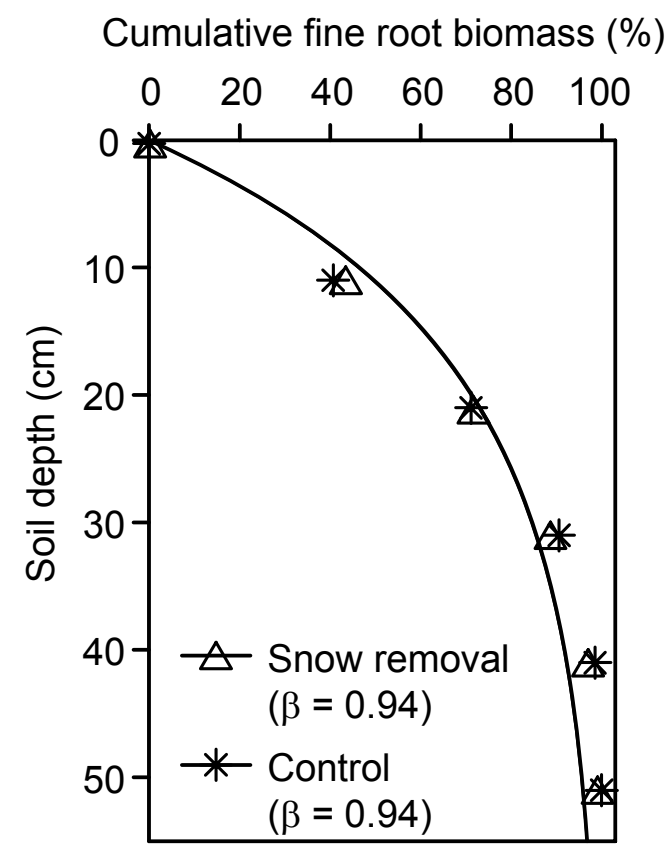

Figure 1: Cumulative vertical fine root biomass distribution in soil profiles of snow removal and control plots as investigated by soil coring 4 months before the onset of the treatment. The degree of fine root biomass decrease with depth is indicated by the $\beta$-values of the regression equation $\mathrm{y}=1-\beta^{\mathrm{d}}$ (Gale and Grigal, 1987), with $\mathrm{y}=$ cumulative fine root biomass fraction in $\mathrm{g}$ $\mathrm{m}^{-2}$ and $\mathrm{d}=$ soil depth. 
Soil thermal conditions in the snow removal treatment and the control plots

Soil frost was induced by manual snow removal from the three treated plots between end of December 2005 and end of February 2006. This treatment led to a significant reduction in the soil temperature until the end of March with several minima as low as $-5.5^{\circ} \mathrm{C}$ while the snow covered control plots never experienced soil frost in this period (Figure 2, Table 2).

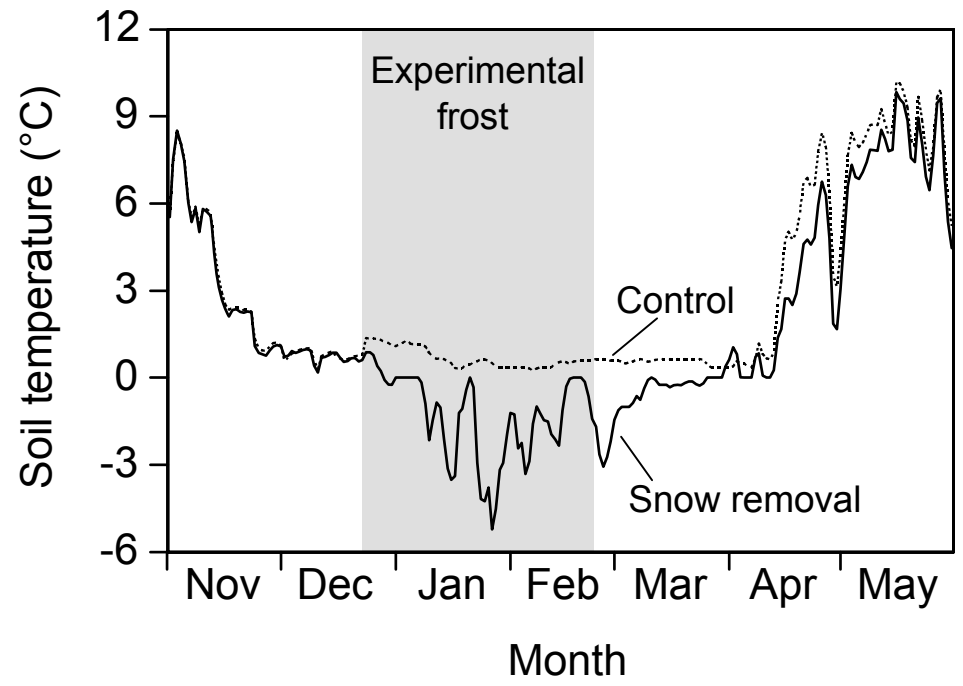

Figure 2: Soil temperature in $5 \mathrm{~cm}$ soil depth (measured from organic layer surface) in the snow removal (solid line) and control (dotted line) plots from November 2005 until May 2006. Given are daily means of five temperature logger stations per plot. The period of experimentally induced soil frost is marked in grey.

Table 2: Mean and minimum temperatures of the organic layer $(5 \mathrm{~cm}$ below organic layer surface) and the mineral soil (at $15 \mathrm{~cm}$ mineral soil depth) in snow removal and control plots during the winter period from December $20^{\text {th }}, 2005$ until March $20^{\text {th }}, 2006$. (Data for mineral soil from Hentschel et al., unpublished)

\begin{tabular}{llcccccc}
\hline & & \multicolumn{3}{c}{ Snow removal } & \multicolumn{3}{c}{ Control } \\
& & SR1 & SR2 & SR3 & C1 & C2 & C3 \\
\hline Mean temperature $\left({ }^{\circ} \mathrm{C}\right)$ & Org. layer & -0.5 & -0.9 & -1.1 & 0.9 & 0.6 & 0.7 \\
& Min. soil & 0.4 & 0.0 & -0.1 & 1.4 & 1.5 & 1.0 \\
Minimum temperature $\left({ }^{\circ} \mathrm{C}\right)$ & Org. layer & -3.6 & -5.1 & -5.3 & 0.5 & 0.0 & 0.2 \\
& Min. soil & -1.1 & -1.9 & -1.5 & 1.0 & 1.0 & 0.7 \\
\hline
\end{tabular}


Mean daily temperature in the organic layer was $0.73^{\circ} \mathrm{C}$ and $-0.83^{\circ} \mathrm{C}$ in the control and the treatment plots, respectively. Hence, the upper soil in the snow removal plots was $1.56{ }^{\circ} \mathrm{C}$ colder on average than in the control plots; the difference in the minimum temperatures was even more pronounced (Table 2). Mean temperature in about $15 \mathrm{~cm}$ mineral soil depth was also lower in the snow removal than in control plots with $0.1{ }^{\circ} \mathrm{C}$ versus $1.3^{\circ} \mathrm{C}$. With the onset of thawing in April, soil temperatures in the snow removal treatment and the control plots approached each other.

Effects of experimental soil frost on fine root biomass and necromass in the organic layer

Sequential soil coring showed that the variation in fine root biomass over time was relatively small in the organic layer; root biomass in the snow removal plots did not change during the frost period while a slight increase in fine root biomass was visible in the control plots (Figure 3A). Ten weeks after thawing, fine root biomass tended to be somewhat reduced in both the treatment and the control plots.
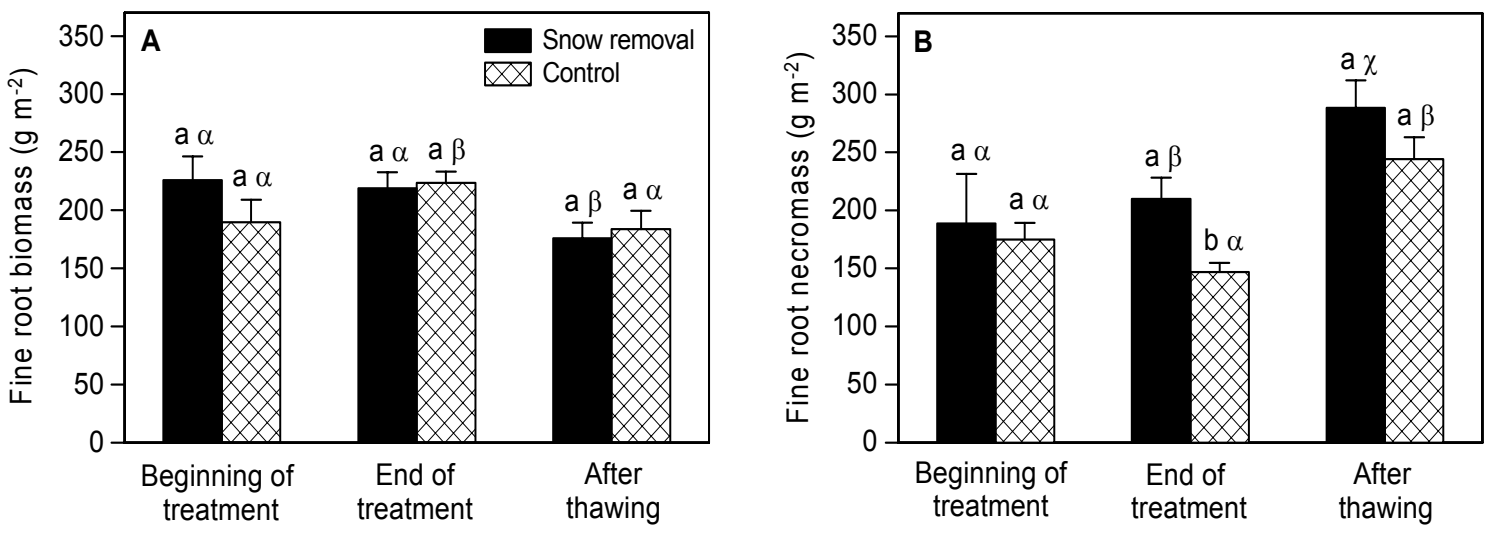

Figure 3: Fine root biomass (A) and necromass (B) in the organic layer of snow removal and control plots (mean $+1 \mathrm{SE}$ ) as investigated by soil coring in $2005 / 06$. Samples were taken at the beginning of snow removal (December $23^{\text {rd }}, 2005$ ), at the end of snow removal (February $23^{\text {rd }}$, 2006) and after thawing (June $5^{\text {th }}, 2006$ ). Different Latin letters indicate significant differences between the treatments at one date, different Greek letters those between different dates for a given treatment.

In contrast, fine root necromass in the organic layer showed a conspicuous response to the soil frost application. Dead root mass in the treated plots increased during the frost period by $11 \%$ while it decreased by $16 \%$ in the control plots in this period leading to a significant difference between both plot types at the end of the snow removal period (Figure 3B). At the end of the follow-up period in June, fine root necromass was 
markedly higher in both plot types showing an increase by $40 \%$ and $53 \%$ in the control and the snow removal plots, respectively, compared to the initial conditions in December.

As a consequence of the observed changes in fine root biomass and necromass, fine root mortality was significantly higher in the organic layer of the snow removal plots than in the control plots during the period of experimental soil frost (Figure 4A). After four weeks of mild soil frost in March and the subsequent 10 frost-free weeks from April to June, nearly the same amount of died fine roots (ca. $31 \mathrm{~g} \mathrm{~m}^{-2} \mathrm{mo}^{-1}$ ) showed up in the snow removal plots. However, cold weather in late winter and thawing in spring led to a significant increase in fine root mortality in the control plots, too.
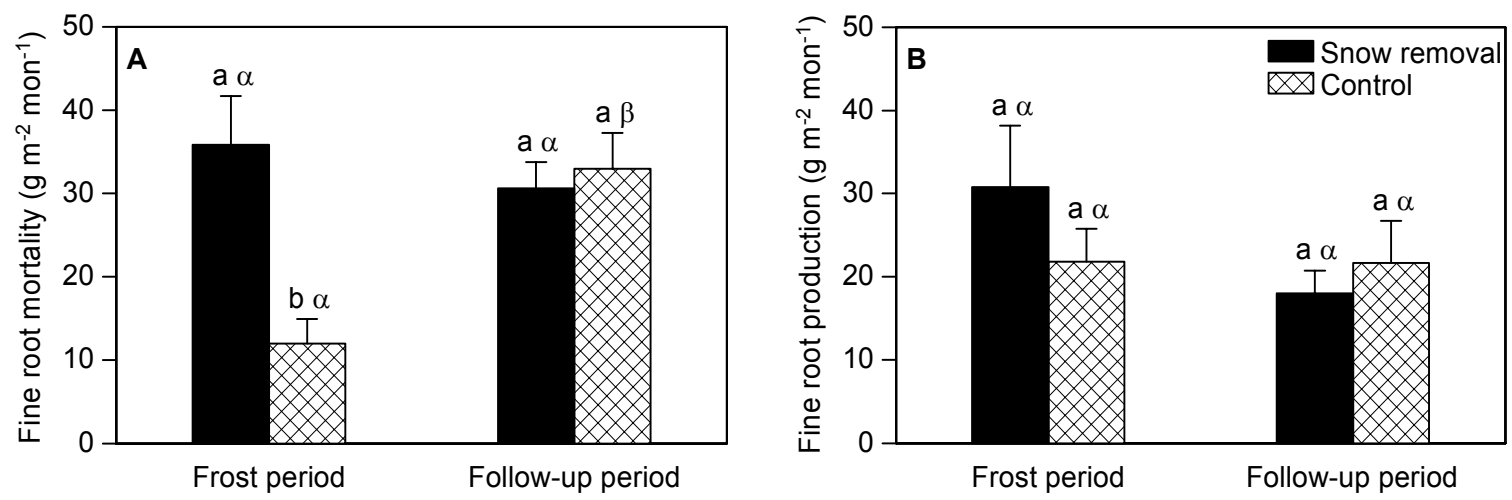

Figure 4: Fine root mortality (A) and production (B) in the organic layer of snow removal and control plots (mean +1 SE) as investigated by soil coring during winter 2005/06. The period of induced soil frost lasted from December 2005 until February 2006 (62 days) while the follow-up period was between February and June 2006 (102 days). Different Latin letters indicate significant differences between the treatments for one measuring period, different Greek letters those between different periods for a given treatment.

In the organic layer of both the snow removal and the control plots, fine root growth continued throughout the winter period according to our sequential coring data. Surprisingly, fine root production tended to be higher in the snow removal plots than in the control plots (Figure 4B). In contrast, fine root production in the snow removal plots was lower during the follow-up period. However, both observations are not based on significant differences in production rates due to the large variation in our data set. With an average of $31 \mathrm{~g} \mathrm{~m}^{-2} \mathrm{mo}^{-1}$, fine root production during the period of experimental soil frost compensated for the simultaneous death of fine roots at a rate of $36 \mathrm{~g} \mathrm{~m}^{-2} \mathrm{mo}^{-1}$. 
Fine root response to soil frost as observed in minirhizotrons

Analysing the minirhizotron images revealed that in both the organic layer and the upper $25 \mathrm{~cm}$ of the mineral soil, mean fine root length tended to be higher in the snow removal than in the control plots at the beginning of the soil frost application (Figure 5). Fine root length in the organic layer of the snow removal plots changed only little during the snow removal period, while in the control plots, fine root length increased in the same time. This difference in root length increase in the upper soil disappeared within 7 weeks after termination of the snow removal, but fine root length in the snow removal plots tended to increase more rapidly than in the control plots during the thawing period. In the upper mineral soil of both plot types, fine root density around the observation tubes was about $65 \%$ lower than in the organic layer. However, fine root length increase in the mineral soil of snow removal and control plots followed the same pattern as observed in the organic layer.

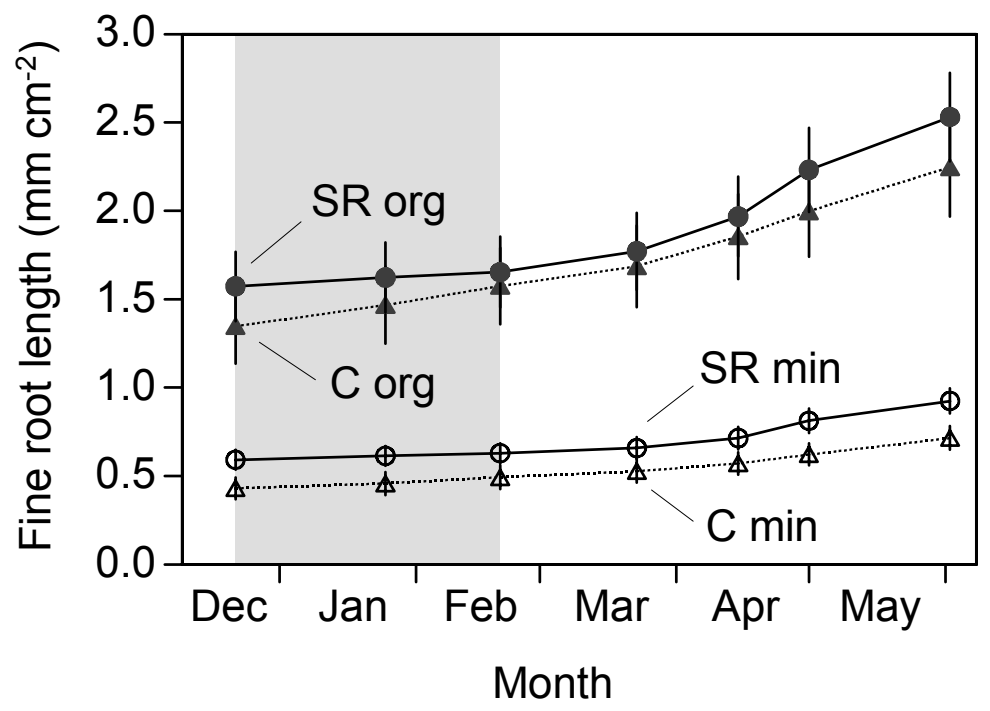

Figure 5: Length of fine root cohorts (mean $\pm 1 \mathrm{SE}$ ) visible in minirhizotrons in the organic layer (org) and the upper ca. $25 \mathrm{~cm}$ of the mineral soil (min) of the snow removal (SR) and control (C) plots between December 2005 and June 2006. The period of snow removal is marked in grey.

Relative fine root loss and production calculated from root length disappearance or emergence between two observation dates in relation to root length initially present at the tubes, were clearly affected by the soil frost treatment (Figure 6A). In the organic layer, the relative loss rate of root length per month was not different between the snow removal and the control plots during the first phase of the soil frost application in January, but it was significantly higher in the snow removal than in the control plots in 
February and March. In the mineral soil, relative loss rates were similar to those in the organic layer.
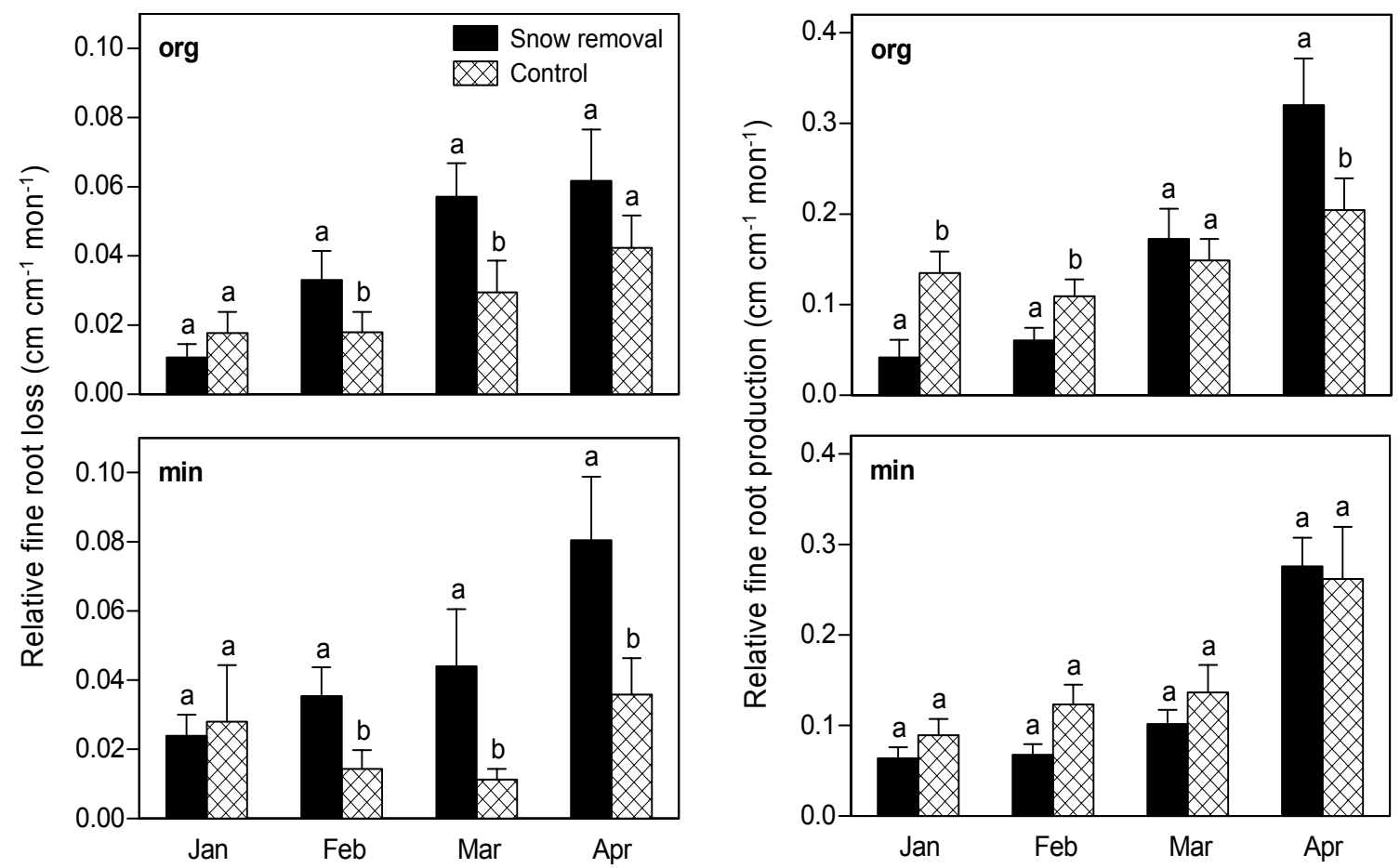

Figure 6: Relative loss (A) and production (B) of fine root length (mean $+1 \mathrm{SE}$ ) in the organic layer (above) and the upper ca. $25 \mathrm{~cm}$ of the mineral soil (below) of the snow removal and control plots as calculated from minirhizotron data. Relative loss and production were calculated from the length of disappearing fine roots (loss) or disappearing fine roots plus fine root length increment (production) between two sampling dates in relation to the standing stock of fine roots of the previous month. Different letters indicate significant differences between the treatments for a given month. Note different scales for loss and production.

Fine root growth occurred even in periods with a mean temperature of about $1{ }^{\circ} \mathrm{C}$ or lower (Figure 6B, Figure 2). In the first phase of the soil frost application period, relative root production was higher in the organic layer of the control compared to the snow removal plots. However, this picture changed in the second part of the frost period and relative root production in the organic layer of snow removal plots exceeded that of the control plots at the end of the treatment (April). In the mineral soil, no significant differences in relative fine root production between snow removal and control plots were observed during the study period.

Both the relative root length loss and relative root length production increased markedly during the winter period from January to April in the snow removal and the control plots. This indicates an endogenous root growth rhythm because soil temperature remained constant from January to March in the control plots. However, relative root length production occurred at a markedly higher rate than root length loss indicating that the 
fine root system in proximity to the minirhizotron tubes had not reached a steady state until the end of our study.

\section{Effects of soil frost on the longevity of spruce fine roots}

Monitoring the impact of experimental soil frost on fine root dynamics in the organic layer by sequential coring and minirhizotron observation allowed us to estimate fine root longevity in the upper soil for both methods. Fine root longevity under low temperature or frost conditions in the snow removal and the control plots was estimated to be 194 and 581 days, respectively, using the sequential coring approach (data not shown). Accordingly, root longevity decreased by a factor of about 3 as a consequence of the soil frost treatment. Root longevity estimates derived from the minirhizotron data were much higher, indicating a mean lifespan of 939 and 1332 days of the fine roots in the snow removal and the control plots (data not shown). However, in accordance with root longevity estimated from sequential coring data, root lifespan at the minirhizotron tubes was reduced by ca. $36 \%$ in the snow removal compared with the control plots. 


\section{Discussion}

Most research concerning effects of soil frost on fine root growth and physiology has been conducted on potted tree seedlings that were exposed to cold treatments of limited duration. Numerous of these studies investigated the frost hardiness of the root system of different Pinus or Picea species (including Picea abies) because these conifers are important timber species in the boreal forest and large numbers of seedlings of these species are cold stored in nurseries.

In general, young roots are more susceptible to frost than mature roots (Lindström and Mattson, 1989; Colombo et al., 1995) and fine root tips seem to be particularly frost sensitive (Smit-Spinks et al., 1985). Large differences in root frost hardiness exist between different tree species. For example, root systems of spruces seem to be generally more tolerant against soil frost than those of pines (Bigras and Dumais, 2005). According to Bigras et al. (2001), the root system of spruce as a whole has a maximum cold tolerance of $<-20^{\circ} \mathrm{C}$ and Hansen et al. (1996) found that Picea abies trees are able to maintain root growth at temperatures close to zero and thus may continue slow root growth throughout the winter period. Tree roots acclimatize to low temperatures by accumulation of soluble carbohydrates (Tinus et al., 2000), induced by a lowering of soil temperatures to about $5{ }^{\circ} \mathrm{C}$ (Bigras and D'Aoust, 1993). Accumulation of soluble sugars is known to serve as a cryoprotecting mechanism in root cells. On the other hand, soluble sugars increase the growth potential of roots after a cold period (Burr at al., 1989).

Root systems of trees have been found to be particularly sensitive to frost damage during freeze-thaw cycles, which may hit the roots in a dehardened state increasing the risk of xylem embolism and possible tree dieback (Schaberg et al., 1996; Ögren et al., 1997). However, the root system of seedlings of spruces and other conifers was found to be capable of rapid recovery after severe losses in fine root biomass had occurred. How sensitive Norway spruce roots are to frost damage, is highly dependent on tree age, the availability of carbohydrates in the roots and the degree of frost hardening of the roots.

The results of our frost experiment in a mature Picea abies forest show that even mild soil frost (8-wk treatment with minima of ca. $-5^{\circ} \mathrm{C}$ ) significantly increased fine root mortality in comparison to the control plots, which were covered by snow and never experienced below-zero temperatures. This is evident from the replicated coring study, which showed a significant increase in fine root necromass by more than $50 \mathrm{~g} \mathrm{~m}^{-2}$ in the organic layer of the snow removal plots at the end of the treatment. Based on the 
compartmental flow calculation approach after Fairley and Alexander (1985), we estimated that the fine root mortality rate in this upper layer had increased by about 25 $\mathrm{g} \mathrm{m}^{-2} \mathrm{mo}^{-1}$ as a consequence of the soil frost treatment.

The sequential coring approach has been criticized to give unrealistic results for the estimation of fine root production in certain cases (Kurz and Kimmins, 1987; Majdi, 1996; Hendricks et al., 2006); instead, direct observation of root growth and death in minirhizotrons has recently found higher acceptance (Smit et al., 2000; Hendricks et al., 2006; Majdi et al., 2007). In our study, however, we would suggest to handle the results derived from the minirhizotron method with some care. In ecosystems with woody plants, the beginning of image collection is often delayed by about 6-8 months after tube installation to allow for fine root recovery to steady state conditions (Hendricks et al., 2006; Mainiero and Kazda, 2006; Withington et al., 2006). In our study, however, fine root production was higher than fine root loss by a factor of about 4 throughout the complete sampling period indicating that the root system in proximity to the minirhizotron tubes had not reached equilibrium until more than 10 months after tube installation. As a consequence, our observations might not only reflect actual root dynamics but also mirror fine root response to soil disturbance (Joslin and Wolfe, 1999). We propose that slow fine root growth rates at our mountainous study site delayed steady state conditions in the root population.

Nevertheless, our data from the minirhizotron approach agree well with the results from sequential soil coring. According to the image analysis, fine root mortality tended to be higher in both, the organic layer and the upper part of the mineral soil of the snow removal plots compared to the control plots in the period from January to April; however, the differences were not significant at $p<0.05$. The minirhizotron images showed a significant increase in fine root birth in the period before April in the organic layer of the snow removal plots indicating a compensatory burst of fine root growth after the elevated root loss due to frost effects in the preceding months. Thus, it appears that the root system of mature spruce trees responds sensitively to even mild soil frost, but is able to compensate for these losses rapidly within short time. Our findings of accelerated fine root production and mortality as a response to experimentally induced soil frost were supported by Muhr et al. (unpublished), who showed that autotrophic respiration in the soil was higher in the snow removal plots than in the control plots in 2006.

Compared with data from sequential coring, root longevity estimates based on minirhizotron data were substantially higher for both plot types. We propose that this difference was mainly caused by compensation growth of fine roots due to soil 
disturbance after tube installation as described above. However, longevity values obtained from minirhizotron observations are generally expected to underestimate actual fine root longevity (Tierney and Fahey, 2002). Independently of the method used, experimental soil frost led to an increase in fine root turnover, thereby reducing the estimated root lifespan in the snow removal plots compared to the control plots.

Our data indicate that the 8-wk soil frost event resulted in a burst of dying of fine roots in the organic layer, which amounted at an extra input of root necromass to the soil of ca. $47 \mathrm{~g} \mathrm{~m}^{-2}$ corresponding to an excess flux of about $21 \mathrm{~g} \mathrm{C} \mathrm{m}^{-2}$ and $0.7 \mathrm{~g} \mathrm{~N} \mathrm{~m}^{-2}$ from decaying roots. This finding is in accordance with the assumption of Matzner and Borken (in press) from a literature study that the carbon pool of forest soils in certain areas might increase in future as a consequence of enhanced root litter input due to more frequent freeze-thaw events.

The results of our minirhizotron observations showed that experimental soil frost did not only enhance fine root mortality in the organic layer but also, to a similar degree, in the upper ca. $25 \mathrm{~cm}$ of the mineral soil. Considering that fine root mass in our research plots was comparable in the organic layer and the upper $25 \mathrm{~cm}$ of the mineral soil, we claim that experimentally induced soil frost led to a total additional input of about $42 \mathrm{~g} \mathrm{C}$ $\mathrm{m}^{-2}$ and $1.4 \mathrm{~g} \mathrm{~N} \mathrm{~m}^{-2}$ to the soil.

Our findings are in line with the results of Tierney et al. (2001) who recognized an enhanced root litter input due to enhanced fine root mortality in a northern hardwood forest in New Hampshire (USA) after applying a mild freezing treatment (to $-4{ }^{\circ} \mathrm{C}$ ) for 12 weeks. However, their estimates for additional fine root mortality $\left(30 \mathrm{~g} \mathrm{~m}^{-2}\right)$ and nitrogen fluxes $\left(0.5 \mathrm{~g} \mathrm{~m}^{-2}\right)$ were lower than ours, indicating a relatively higher frost sensitivity of the fine root system of Norway spruce. Tierney et al. (2001) concluded that frostinduced root mortality may lead to elevated levels of nitrification and subsequent losses of $\mathrm{N}$ and $\mathrm{P}$ through leaching because nutrient mineralization from decaying roots occurs in a period of reduced plant uptake. Interestingly, the same authors found in laboratory experiments with potted tree seedlings that the mild freezing temperatures in the forest were insufficient to cause fine root death (Tierney et al. 2001). They conclude that the elevated root mortality was caused indirectly by mechanical damage to roots in frozen soil. In the light of the cold sensitivity data of Hansen et al. (1996), Bigras et al. (2001) and Coleman et al. (1992), it may well be that hardened spruce roots in the Fichtelgebirge forest were not damaged by the soil frost directly but by the forming of ice in the soil, which will be a rare event in deeper soil layers as long as snow cover exists. 
We conclude that increased frequencies of freeze-thaw events in the frame of global change will affect Norway spruce root systems through elevated fine root mortality leading to an additional input of root-derived carbon into the soil. Mild soil frost may stimulate compensatory fine root growth, which mitigates the negative effects of fine root loss but draws on the carbohydrate reserves of the trees, thereby possibly reducing above-ground productivity.

\section{Acknowledgements}

We thank Irmgard Gerstmann for her skillful support during the fine root analyses. Egbert Matzner and Werner Borken coordinated the research group. Gerhard Müller, Uwe Hell and Andreas Kolb from Bayreuth Center of Ecology and Environmental Research (BayCEER) provided technical assistance during installation and operation of the research plots. Two anonymous reviewers provided valuable comments on the manuscript. The financial support by DFG (Deutsche Forschungsgemeinschaft) granted in the framework of the Research Group "Bodenprozesse" FOR 562 is gratefully acknowledged. 


\section{References}

Alavi, G. (1996): Radial stem growth of Picea abies in relation to spatial variation in soil moisture conditions. Scan. J. Forest Res. 11, 209-219.

Bauhus, J., Bartsch, N. (1996): Fine-root growth in beech (Fagus sylvatica) forest gaps. Can. J. For. Res. 26, 2153-2159.

Bigras, F. J., D'Aoust, A. L. (1993): Influence of photoperiod on shoot and root frost tolerance and bud phenology of white spruce seedlings (Picea glauca). Can. J. For. Res. 23, 219-228.

Bigras, F. J., Dumais, D. (2005): Root-freezing damage in the containerized nursery: impact on plantation sites - A review. New Forests 30, 167-184.

Bigras, F. J., Ryyppo, A., Lindstöm, A., Stattin, E. (2001): Cold acclimation and deacclimation of shoots and roots of conifer seedlings, in Bigras, F.J., Colombo, S.J.: Conifer Cold Hardiness. Kluwer Academic Publishers, Dordrecht, pp. 57-88.

Blanck, K., Lamersdorf, N., Dohrenbusch, A., Murach, D. (1995): Response of a Norway spruce forest ecosystem to drought/rewetting experiments at Solling, Germany. Water Air Soil Poll 85, 1251-1256.

Burr, K. E., Tinus, R. W., Wallner, S. J., King, R. M. (1989): Relationships among cold hardiness, root growth potential and bud dormancy in three conifers. Tree Physiol. 5, 291-306.

Christensen, J. H., Christensen, O. B. (2003): Climate modelling: Severe summertime flooding in Europe. Nature 421, 805-806.

Clemensson-Lindell, A., Persson, H. (1995): Fine-root vitality in a Norway spruce stand subjected to various nutrient supplies. Plant Soil 168/169, 167-172.

Coleman, W. K., Estabrooks, E. N., O'Hara, M., Embleton, J., King, R. (1992): Seasonal changes in cold hardiness, sucrose and sorbitol in apple trees treated with plant growth regulators. J. Hortic. Sci. 67, 429-435.

Colombo, S. J., Zhao, S., Blumwald, E. (1995): Frost hardiness gradients in shoots and roots of Picea mariana seedlings. Scand. J. For. Res. 10, 32-36.

Davidson, E. A., Savage, K., Bolstad, P., Clark, D. A., Curtis, P. S., Ellsworth, D. S., Hanson, P. J., Law, B. E., Luo, Y., Pregitzer, K. S., Randolph, J. C., Zak, D. (2002): Below-ground carbon allocation in forests estimated from litterfall and IRGA-based soil respiration measurements. Agric. For. Meteorol. 113, 39-51.

Eissenstat, D. M., Yanai, R. D. (1997): The ecology of root lifespan. Adv. Ecol. Res. 27, $1-60$.

Fairley, R. I., Alexander, I. J. (1985): Methods of calculation fine root production in forests, in Fitter, A.H., Atkinson, D., Read, D.J.: Ecological interactions in soil: plants, microbes and animals. Blackwell Scientific Publications Oxford, U.K., pp. 37-42.

Fogel, R., Hunt, G. (1983): Contribution of mycorrhizae and soil fungi to nutrient cycling in a Douglas-fir ecosystem. Can. J. For. Res. 13, 219-232.

Foken, T. (2003): Lufthygienisch-Bioklimatische Kennzeichnung des oberen Egertales. Bayreuther Forum Ökologie 100, 1-118.

Gale, M. R., Grigal, D. F. (1987): Vertical root distributions of northern tree species in relation to successional status. Can. J. For. Res. 17, 829-834.

Godbold, D. L., Fritz, H. W., Jentschke, G., Meesenburg, H., Rademacher, P. (2003): Root turnover and root necromass accumulation of Norway spruce (Picea abies) are affected by soil acidity. Tree Physiol 23, 915-921. 
Guo, L. B., Halliday, M. J., Siakimotu, S. J. M., Gifford, R. M. (2005): Fine root production and litter input: its effect on soil carbon. Plant Soil 272, 1-10.

Hansen, J., Vogg, G., Beck, E. (1996): Assimilation, allocation and utilization of carbon by 3 -year-old Scots pine (Pinus sylvestris L.) trees during winter and early spring. Trees 11, 83-90.

Hendricks, J. J., Hendrick, R. L., Wilson, C. A., Mitchell, R. J., Pecot, S. D., Guo, D. L. (2006): Assessing the patterns and controls of fine root dynamics: an empirical test and methodological review. J. Ecol. 94, 40-57.

Hentschel, K., Borken, W., Matzner, E. Leaching losses of inorganic N and DOC following repeated drying and wetting of a spruce forest soil. Plant Soil (in press).

Hertel, D. (1999): Das Feinwurzelsystem von Rein- und Mischbeständen der Rotbuche: Struktur, Dynamik und interspezifische Konkurrenz. Dissertationes Botanicae 317. Gebrüder Borntraeger, Stuttgart, Germany, p. 206.

Hogberg, P., Hogbom, L., Schinkel, H. (1998): Nitrogen-related root variables of trees along an N-deposition gradient in Europe. Tree Physiol 18, 823-828.

Hulme M., Sheard N. (1999): Climate Change Scenarios for Germany. Climate Research Unit, Norwich, UK, p.6.

IUSS Working Group WRB (2006): World reference base for soil resources 2006. $2^{\text {nd }}$ edition. World Soil Resources Report No. 103, FAO, Rome.

Jackson, R. B., Mooney, H. A., Schulze, E. D. (1997): A global budget for fine root biomass, surface area, and nutrient contents. Proc. Nat. Acad. Sci. 94, 73627366.

Jentschke, G., Drexhage, M., Fritz, H.-W., Fritz, E., Schella, B., Lee, D. H., Gruber, F., Heimann, J., Kuhr, M., Schmidt, J., Schmidt, S., Zimmermann, R., Godbold, D. L. (2001): Does soil acidity reduce subsoil rooting in Norway spruce (Picea abies)? Plant Soil 237, 91-108.

Johns, T. C., Gregory, J. M., Ingram, W. J., Johnson, C. E., Jones, A., Lowe, J. A., Mitchell, J. F. B., Roberts, D. L., Sexton, D. M. H., Stevenson, D. S., Tett, S. F. B., Woodage, M. J. (2001): Anthropogenic climate change for 1860 to 2100 simulated with the HadCM3 model under updated emissions scenarios. Dept of Meteorology, University of Edinburgh King's Buildings.

Joslin, J. D., Wolfe, M. H. (1999): Disturbances during minirhizotron installation can affect root observation data. Soil Sci. Soc. Am. J. 63, 218-221.

Keyes, M. R., Grier, C. C. (1981): Above- and below-ground net production in 40-yearold Douglas-fir stands on low and high productivity sites. Can. J. For. Res. 11, 599-605.

Kurz, W. A.., Kimmins, J. P. (1987): Analysis of some sources of error in methods used to determine fine root production in forest ecosystems: a simulation approach. Can. J. For. Res. 17, 909-912.

Lal, R. (2005): Forest soils and carbon sequestration. For. Ecol. Manage. 220, 242-258.

Leuschner, Ch., Hertel, D., Coners, H., Büttner, V. (2001): Root competition between beech and oak: a hypothesis. Oecologia 126, 276-284.

Lindström, A., Mattsson, A. (1989): Equipment for freezing roots and its use to test cold tolerance of young and mature roots of Picea abies seedlings. Scand. J. For. Res. 4, 59-66.

Mainiero, R., Kazda, M. (2006): Depth-related fine root dynamics of Fagus sylvatica during exceptional drought. For. Ecol. Manage. 237, 135-142. 
Majdi, $H$. (2001): Changes in fine root production and longevity in relation to water and nutrient availability in a Norway spruce stand in northern Sweden. Tree Physiol 21, 1057-1061.

Majdi, H. (1996): Root sampling methods - applications and limitations of the minirhizotron technique. Plant Soil 185, 255-258.

Majdi, H., Nylund, J.-E., Agren, G. (2007): Root respiration data and minirhizotron observations conflict with root turnover estimates from sequential soil coring. Scand. J. Forest Res. 22, 299-303.

Makinen, H., Nojd, P., Mielikainen, K. (2000): Climatic signal in annual growth variation of Norway spruce (Picea abies) along a transect from central Finland to the Arctic timberline. Can. J. For. Res. 30, 769-777.

Matzner, E., Borken, W. (2008): Do freeze-thaw events enhance $C$ and $N$ losses from soils of different ecosystems? - a review. Eur. J. Soil Sci. (in press).

McClaugherty, C. A., Aber, J. D., Melillo, J. M. (1982): The role of fine roots in the organic matter and nitrogen budgets of two forested ecosystems. Ecology 63, 1481-1490.

Nadelhoffer, K. J. (2000): The potential effects of nitrogen deposition on fine-root production in forest ecosystems. New Phytol. 147, 131-139.

Ögren, E. (1997): Relationship between temperature, respiratory loss of sugar and premature dehardening in dormant Scots pine seedlings. Tree Physiol. 17, 47-51.

Ostonen, I., Lohmus, K., Lasn, R. (1999): The role of soil conditions in fine root ecomorphology in Norway spruce (Picea abies (L.) Karst.). Plant Soil 208, 283292.

Persson, H., Ahlström, K. (2002): Fine-root response to nitrogen supply in nitrogen manipulated Norway spruce catchment areas. For. Ecol. Manage. 168, $29-41$.

Persson, H. (1978): Root dynamics in a young Scots pine stand in Central Sweden. Oikos 30, 508-519.

Persson, H., Von Fircks, Y., Majdi, H., Nilsson, L. O. (1995): Root distribution in a Norway spruce (Picea abies (L.) Karst.) stand subjected to drought and ammonium-sulphate application. Plant Soil 168/169, 161-165.

Powell, S. W., Day, F. P. (1991): Root production in four communities in the Great Dismal Swamp. Amer. J. Bot. 78, 288-297.

Schaberg, P. G., Shane, J. B., Hawley, G. J., Strimbeck, G. R., DeHayes, D. H., Cali, P. F., Donnelly, J. R. (1996): Physiological changes in red spruce seedlings during a simulated winter thaw. Tree Physiol. 16, 567-574.

Schlesinger, W. H. (1997): Biogeochemistry. An analysis of global change, $2^{\text {nd }}$ edition. Academic Press, San Diego.

Smit, A. L., George, E., Groenwold, J. (2000): Root observations and measurements at (transparent) interfaces with soil. In: Smit, A. L. Bengough, A. G., Engels, C., Van Noordwijk, M., Pellerin, S., Van de Geijn, S. C. Root methods. Springer-Verlag, Berlin, pp. 235-256.

Smit-Spinks B., Swanson B. T., Markhart A. H. (1985): The effect of photoperiod and thermoperiod on cold acclimation and growth of Pinus sylvestris. Can. J. For. Res. $15,453-460$.

Spiecker, H. (1995): Growth dynamics in a changing environment: Long-term observations. Plant Soil 168/169, 555-561.

Tierney, G. L., Fahey, T. J., Groffman, P. M., Fitzhugh, R. D., Driscoll, C. T. (2001): Soil freezing alters fine root dynamics in a northern hardwood forest. Biogeochemistry $56,175-190$. 
Tierney, G. L., Fahey, T. J. (2002): Fine root turnover in a northern hardwood forest: a direct comparison of the radiocarbon and minirhizotron methods. Can. J. For. Res. 32, $1692-7$.

Tinus, R. W., Burr, K. E., Atzmon, N., Riov, J. (2000): Relationship between carbohydrate concentration potential in coniferous seedlings from three hardening and dehardening. Tree Physiol. 20, 1097-1104.

van Praag, H. J., Sougnez-Remy, S., Weissen, F., Carletti, G. (1988): Root tunover in a beech stand of the Belgian Ardennes. Plant Soil 105, 87-103.

Vogt, K. A., Vogt, D. J., Bloomfield, J. (1998): Analysis of some direct and indirect methods for estimating root biomass and production. Plant Soil 200, 71-89.

Withington, J. M., Reich, P. B., Olecksyn, J., Eissenstat, D. M. (2006) Comparisons of structure and life span in roots and leaves among temperate trees. Ecol Monogr 76:381-397. 


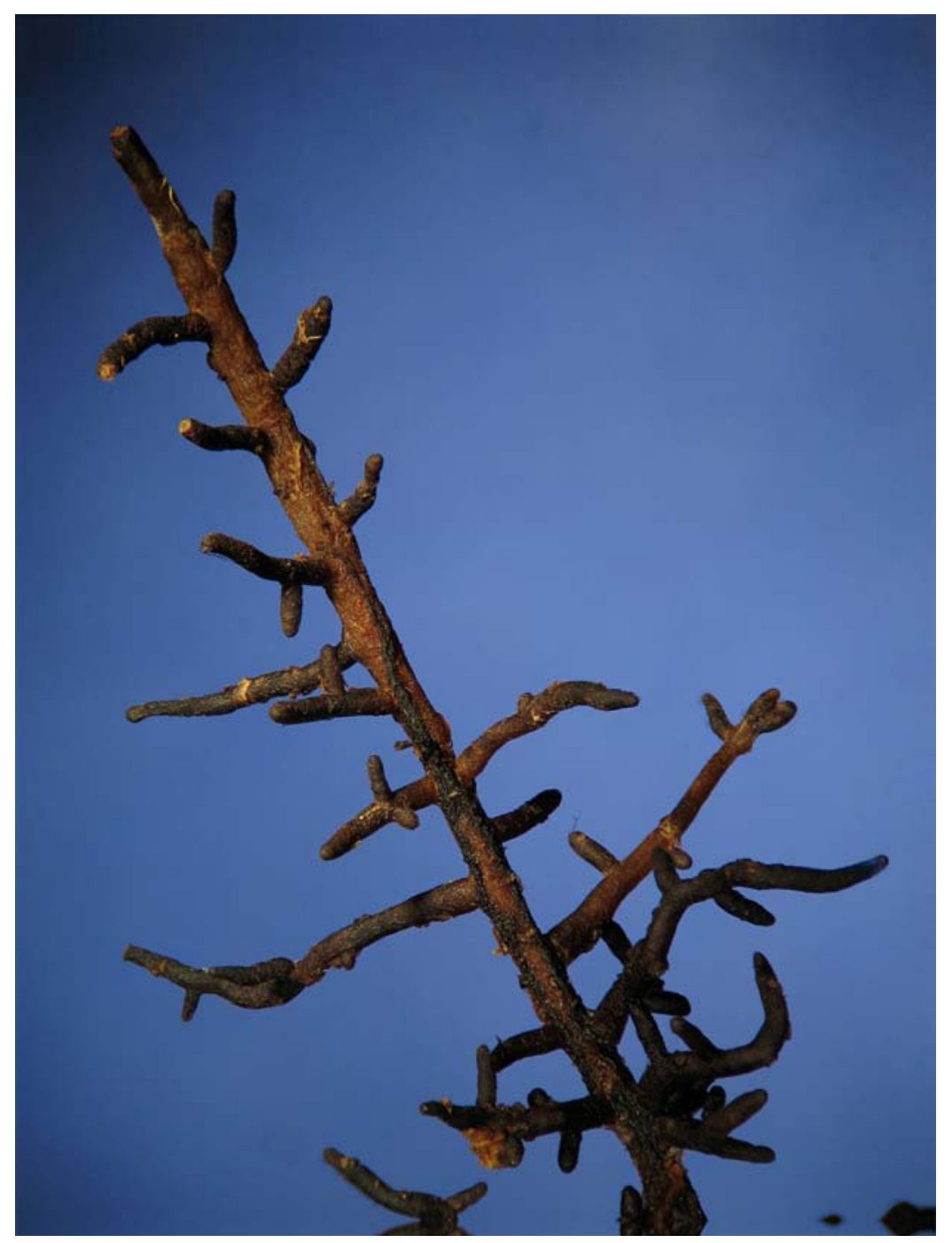


Chapter 4

Estimating fine root longevity in a temperate Norway spruce forest using three independent methods 


\section{Summary}

The importance of root systems for $\mathrm{C}$ cycling depends crucially on fine root longevity. In a temperate Norway spruce (Picea abies (L.) Karst.) forest, we investigated fine root longevity distribution with root diameter, root $\mathrm{C} / \mathrm{N}$ ratio and soil depth using radiocarbon $\left({ }^{14} \mathrm{C}\right)$ analyses. In addition, we applied sequential soil coring and minirhizotron observations to estimate fine root longevity in the organic layer of the same stand. We found that the mean age of $\mathrm{C}$ in fine roots increased with depth from 5 years in the organic layer to 13 years in $40-60 \mathrm{~cm}$ mineral soil depth. Similarly, the $\mathrm{C} / \mathrm{N}$ ratios of fine root samples were lowest in the organic layer with a mean value of 24 and increased at a rate of $10 \%$ per $10 \mathrm{~cm}$ increase in soil depth. Roots $>0.5 \mathrm{~mm}$ in diameter tended to live longer than those being $<0.5 \mathrm{~mm}$ in diameter. By far the strongest variability in fine root longevity estimates was due to the chosen method of investigation, with radiocarbon analyses yielding much higher estimates $(5.4 \mathrm{yr})$ than sequential soil coring (0.9 yr) and minirhizotron observations $(0.7 \mathrm{yr})$. The ${ }^{14} \mathrm{C}$ concentrations in fresh fine roots and needles collected in 2007 were similar to those in atmospheric $\mathrm{CO}_{2}$ of the same year. Hence, the construction of new root tissue with $C$ from storage pools is unlikely to be the reason for elevated fine root longevity estimates as obtained by radiocarbon analyses. We conclude that sequential soil coring and minirhizotron observations are likely to underestimate mean fine root longevity, while radiocarbon analyses may lead to an overestimation of mean root longevity.

Key words: fine root diameter, minirhizotrons, radiocarbon, root $\mathrm{C} / \mathrm{N}$ ratio, root turnover, sequential coring 


\section{Introduction}

Fine roots represent a relatively small but important element of $\mathrm{C}$ cycling in forest ecosystems (Schlesinger 1997). On a global scale, fine root growth is estimated to consume about $30 \%$ of the C fixed through photosynthesis (Jackson et al. 1997). However, this estimation is based on the increasingly controversial assumption that fine roots grow and die within one year.

In a meta-analysis comprising 59 studies, Gill and Jackson (2000) found that estimated fine root turnover times ranged from 5 months to 2 years. Fine root longevity varies between different types of vegetation and is affected by soil conditions like temperature, moisture and nutrient availability (Pregitzer et al. 1993; Gaul et al. 2008; Graefe et al. 2008). In addition, there is increasing evidence that different components of the same fine root system cycle $C$ at very different rates. Particularly root diameter, root order and soil depth may substantially influence the longevity, and therefore the sink strength of fine roots for C (Wells and Eissenstat 2001; Gaudinski et al. 2001; Joslin et al. 2006). More recently, the method of investigation has also been considered to significantly influence the estimate of root longevity. Mean fine root longevities in the order of several years, as they are often indicated by isotope-based studies, are increasingly leading to doubts about the potential of fine roots to be an outstanding $C$ sink.

Today, there exists a great variety of independent methods for monitoring fine root dynamics in forest soils. The most promising and frequently used approaches for estimating root longevity include sequential soil coring, direct observation using minirhizotrons and isotopic $\left({ }^{13} \mathrm{C}\right.$ and $\left.{ }^{14} \mathrm{C}\right)$ analyses (Pritchard and Strand 2008). All of these techniques have their advantages and shortcomings (Majdi et al. 2005; Hendricks et al. 2006).

Sequential soil coring was among the first methods used to estimate changes in fine root biomass and necromass over time. Based on the data obtained from sequential coring, fine root production and longevity can be calculated by different procedures. The most common approach is the minimum-maximum method, which equates the difference between minimum and maximum fine root mass during a year with annual fine root production (Edwards and Harris 1977; McClaugherty et al. 1982). Root turnover (the inverse of longevity) is calculated by relating annual root production to standing root biomass (Gill and Jackson 2000). Sequential coring in combination with the minimum-maximum method is criticized as being an indirect approach to estimate fine root production and longevity, which is based on tenuous assumptions (Hendricks et al. 2006; Majdi et al. 2007). In fact, the minimum-maximum method assumes that 
root production and mortality occur in different periods and that no additional peak or low of standing root mass occurs between the sampling dates (Singh et al. 1984; Kurz and Kimmins 1987).

The minirhizotron method is increasingly suggested to provide more realistic results on fine root dynamics than sequential soil coring (Publicover and Vogt 1993; Hendricks et al. 2006; Majdi et al. 2007). It is a non-destructive approach that allows for in-situ observation of individual fine roots over defined time intervals. Fine root lifespan or longevity can be directly observed by tracking roots from their first appearance until their death. One limitation of this method is the difficulty of distinguishing between live and dead roots on minirhizotron images (Comas et al. 2000; Withington et al. 2006). In addition, soil disturbance after tube installation and the tubes themselves can influence fine root longevity (Joslin and Wolfe 1999; Withington et al. 2003).

More recently, Gaudinski et al. (2001) introduced a new approach to estimate the longevity of fine roots based on the radiocarbon concentrations in root mass. $\Delta^{14} \mathrm{C}$ of root material is measured and compared to the historic record of $\Delta^{14} \mathrm{C}$ in atmospheric $\mathrm{CO}_{2}$. Mean fine root lifetime or longevity is equated with the time period between $\mathrm{C}$ fixation in root tissue and sampling date. Radiocarbon analyses are criticized to overestimate fine root longevity because the finest, most ephemeral roots are likely to be underrepresented and new fine roots may be constructed with $C$ from storage pools (Strand et al. 2008). While sequential coring and minirhizotron observations usually yield fine root longevity estimates of less than one year, radiocarbon data indicate that tree fine roots live for more than 4 years on average (Gaudinski et al. 2001; Tierney and Fahey 2002; Trumbore et al. 2006).

The importance of reliable data on fine root longevity for quantifying $C$ fluxes in forests is increasingly recognized. Currently, there is an intensive debate on the efficacy of different methods for investigating fine root longevity (Strand et al. 2008). Most of the studies on root turnover and longevity applied only one method although multiple assessment techniques are widely recommended for the investigation of root dynamics (Vogt et al. 1998; Hertel and Leuschner 2002; Hendricks et al. 2006). We are not aware of any study that has applied more than two independent methods to estimate fine root longevity for the same site until now.

We used sequential soil coring, minirhizotron observations and radiocarbon dating to investigate fine root longevity in a mature Norway spruce stand in Southeast Germany. Our main objectives were (i) to compare three independent methods for estimating fine root longevity and (ii) to assess the variation in fine root longevity with root diameter, root $\mathrm{C} / \mathrm{N}$ ratio and soil depth. 


\section{Materials and methods}

\section{Study site}

The study was conducted in a mature Norway spruce (Picea abies (L.) Karst.) forest at an elevation of about $770 \mathrm{~m}$ a.s.I. in the Fichtelgebirge, Southeast Germany $\left(50^{\circ} 08^{\prime} \mathrm{N}\right.$, $11^{\circ} 52$ 'E). Mean annual precipitation is approximately $1160 \mathrm{~mm}$ and mean annual air temperature is $5.3^{\circ} \mathrm{C}$ (Foken 2003). The soil developed from granite and is classified as Haplic Podsol (IUSS, 2006) with sandy to loamy texture. The pH values $\left(\mathrm{H}_{2} \mathrm{O}\right)$ of the soil range from 4.0 in the Oa horizon to 4.5 in the Bw horizon (Hentschel et al. 2007). The $\mathrm{C}$ and $\mathrm{N}$ contents of the soil decreased with soil depth from $18 \% \mathrm{C}$ and $1 \% \mathrm{~N}$ in the $\mathrm{Oa}$ horizon to $0.4 \% \mathrm{C}$ and $<0.05 \% \mathrm{~N}$ in the BW horizon (Hentschel et al. 2007). The base saturation was highest in the Oa horizon with $54 \%$ and decreased to $12-16 \%$ in the subsoil (Hentschel et al. 2007). The thickness of the mor-like organic layer (Oi, Oe, Oa) varies between 5 and $18 \mathrm{~cm}$ and is on average $11 \mathrm{~cm}$. Mean tree age of the pure spruce forest was 140 years and mean tree height was $30 \mathrm{~m}$. The basal area was $45 \mathrm{~m}^{2}$ $\mathrm{ha}^{-1}$ and the stem density was approximately $350 \mathrm{ha}^{-1}$. The patchy ground vegetation was dominated by the grass species Deschampsia flexuosa (L.) and Calamagrostis villosa (Chaix).

Three research plots of about $20 \mathrm{~m} \times 20 \mathrm{~m}$ each were established for the fine root studies. In the centre of every plot, a transect of $13 \mathrm{~m}$ length and $1 \mathrm{~m}$ width was randomly chosen to monitor fine root dynamics through soil coring and minirhizotron observations.

\section{Fine root inventory}

In summer 2005, the mass and vertical distribution of living and dead fine roots $(<2 \mathrm{~mm}$ in diameter) were investigated. Samples were taken with a soil corer $(3.5 \mathrm{~cm}$ in diameter) from the organic layer and the upper $40 \mathrm{~cm}$ of the mineral soil at 12 randomly selected locations along each of the three transects. Every soil core was divided into five soil depth intervals (oganic layer, $0-10 \mathrm{~cm}, 10-20 \mathrm{~cm}, 20-30 \mathrm{~cm}, 30-40 \mathrm{~cm}$ ). The sampling locations were more than $50 \mathrm{~cm}$ apart to avoid clumping and to cope with the spatial heterogeneity of the plots. The root samples were filled in plastic bags and transported to the laboratory in Göttingen, where they were processed within five weeks. In the lab, the samples were washed with water in a sieve $(0.25 \mathrm{~mm}$ mesh size) to clean the roots from soil particles. Subsequently, large roots $(<1 \mathrm{~cm}$ in length) were sorted into living (biomass) and dead (necromass) fractions under the stereomicroscope 
based on color, elasticity and the degree of cohesion of cortex, periderm and stele. If cortex and stele were either dark, non-turgid or missing, fine roots were classified as dead (Persson 1978; Leuschner et al. 2001). This analysis covers the vast majority of the fine root biomass but misses many dead rootlets (Bauhus and Bartsch 1996). In order to consider these smaller root particles as well, we examined half of the samples additionally applying a more detailed procedure following the protocol given by Hertel (1999) and Leuschner et al. (2001). The results were then extrapolated to estimate also the biomass and necromass of fine roots $<1 \mathrm{~cm}$ in length for the remaining samples. The application of this complementary method of root analysis results in much higher fine root necromass values than obtained by conventional analyses. Living and dead fine roots of each sample were dried at $70{ }^{\circ} \mathrm{C}$ for $48 \mathrm{~h}$, weighed, and the data expressed as fine root biomass and necromass abundance $\left(\mathrm{g} \mathrm{m}^{-2}\right)$.

Additionally, all samples of living fine roots containing $>10 \mathrm{mg}$ root mass were grained and analyzed for carbon and nitrogen content using a CNH auto-analyzer (Na-1500, Fa. Carlo Erba Strumentazione, Milan, Italy).

\section{Sequential soil coring approach}

Changes in fine root biomass and necromass over time were monitored by sequential soil coring on seven dates between December 2005 and December 2006. Along each of the three transects, 20 sampling locations were randomly selected. Soil cores of the thick organic layer were taken at a distance of $30 \mathrm{~cm}$ to each other and processed in the same way as described above. Annual fine root production was calculated from the sequential coring data using the minimum-maximum method (Edwards and Harris 1977; McClaugherty et al. 1982). Based on this method, annual fine root production is calculated as the difference between maximum and minimum fine root mass (biomass plus necromass) during the one-year-long sampling period. Fine root turnover was calculated as the ratio of annual fine root production to mean standing fine root biomass (Aber et al. 1985; Aerts et al. 1992). Fine root longevity (in years) is the inverse of fine root turnover.

\section{Minirhizotron approach}

In addition to the sequential coring method, we observed seasonal fine root dynamics in the organic layer in situ through minirhizotrons. Eight transparent plexiglas tubes $(67 \mathrm{~cm}$ 
long $\times 7.0 \mathrm{~cm}$ in diameter) per plot were installed vertically to the soil surface in June 2005. All tubes were sealed at the bottom and closed by removable plastic caps at the top to prevent the entrance of water. The aboveground parts of the minirhizotron tubes were laminated with tape to avoid the penetration of sunlight to the soil. After the installation of the minirhizotrons, the first image collection was delayed by six months in order to allow for a steady state of fine root density in proximity to the tubes (Joslin and Wolfe 1999). Between December 2005 and December 2006, colored images with a resolution of 200 dpi were taken approximately every four weeks using a scanner system (Cl-600 Root Growth Monitoring System, CID, USA). From the recorded soil compartment, about $80 \mathrm{~cm}^{2}$ were selected to monitor temporal changes of fine root length. In this study, fine root dynamics were only investigated in the densely rooted organic soil layer, which accounted for about $40 \%$ of the fine root biomass profile total. The images were analyzed with the program WinRHIZOTron (Régent Instruments, Quebec, Canada). Because of difficulties in determining the vitality status of fine roots based on their color (Tingey et al. 2000; Withington et al. 2006), we classified all present roots as living and disappeared roots as dead. As a consequence, our study overestimates fine root longevity due to the time lag between death and disappearance of fine roots. Root birth and death were assumed to have occurred halfway between two successive dates of image collection. We divided fine roots into two size classes (roots $<0.5 \mathrm{~mm}$ in diameter and roots between 0.5 and $2 \mathrm{~mm}$ in diameter) to cope with functional differences of different diameter classes (Pregitzer et al. 1998; Wells and Eissenstat 2001). We tracked all fine roots $<0.5 \mathrm{~mm}$ in diameter, which first appeared in January and July 2006 until their disappearance or the end of the study. Fine roots > $0.5 \mathrm{~mm}$ in diameter were less abundant and two cohorts of roots born between January and March 2006 and between June and July 2006 were tracked in the same way. Root lifespan was calculated as the number of days from root birth until root death.

\section{Radiocarbon approach}

We estimated the mean age of $C$ in fine roots of different size classes and soil depths by radiocarbon $\left(\Delta^{14} C\right)$ analyses. In proximity to the research transects, 10 holes of 60 $\mathrm{cm}$ depth were dug. Fine root material for 1-2 root samples per size class and soil depth was picked manually from each hole using forceps. Ninety fine root samples collected by this procedure were composed as following: roots $<0.5 \mathrm{~mm}$ in diameter from the organic layer $(n=12)$; roots between 0.5 and $1 \mathrm{~mm}$ in diameter from the organic layer $(n=10)$; roots between 1 and $2 \mathrm{~mm}$ in diameter from the organic layer $(n=10)$; roots $<2$ 
$\mathrm{mm}$ in diameter for the upper $10 \mathrm{~cm}$ of the mineral soil $(\mathrm{n}=12)$; roots $<2 \mathrm{~mm}$ in diameter at $10-20 \mathrm{~cm}$ mineral soil depth $(\mathrm{n}=12)$; roots $<2 \mathrm{~mm}$ in diameter at $20-40 \mathrm{~cm}$ mineral soil depth $(n=12)$; roots $<1 \mathrm{~mm}$ in diameter at 40-60 $\mathrm{cm}$ mineral soil depth $(\mathrm{n}=12)$ and roots between 1 and $2 \mathrm{~mm}$ in diameter at 40-60 $\mathrm{cm}$ mineral soil depth $(\mathrm{n}=10)$. Under a stereomicroscope, the root samples were separated into living and dead fractions as described above. Additionally, samples of fine root biomass $(n=10)$ and necromass $(n=10)$ obtained from sequential soil coring in the organic layer of the study location in June 2006 were used for radiocarbon analyses.

In order to find out whether the radiocarbon contents of plant tissue reflect the actual fine root ages, we collected fresh needles $(n=10)$ and roots $(n=10)$ in July 2007 . Fresh needles were picked from mature spruce trees growing in proximity to the research transects. They could be easily differentiated from older ones due to their lighter color and their position at the end of the twigs. Horizontally installed root screens allowed us to identify roots known to be less than 8 months old in June 2007. These roots were then hand-picked from the soil with forceps and used to measure $\Delta^{14} \mathrm{C}$ values of fresh fine root material .

All samples $(n=130)$ were carefully cleaned from soil residues, oven-dried at $70{ }^{\circ} \mathrm{C}$ for $48 \mathrm{~h}$ and ground. We applied an acid/alkali/acid treatment according to Gaudinski et al. (2001) to remove non-structural carbohydrates, which may post-date root formation. The samples were oven-dried at $70{ }^{\circ} \mathrm{C}$ for $48 \mathrm{~h}$ again and sent to the accelerator mass spectrometry (AMS) Radiocarbon Analysis Laboratory in Jena, Germany, where they were converted to graphite and measured for ${ }^{14} \mathrm{C}$ content. Radiocarbon data is expressed as $\Delta^{14} \mathrm{C}$, which is equivalent to the ${ }^{14} \mathrm{C} /{ }^{12} \mathrm{C}$ ratio per mil of a sample divided by that of a universal standard (oxalic acid nr 1 in AD 1950) corrected to a common $\Delta^{13} \mathrm{C}$ value of $-25 \%$

We determined the time of root formation as the year in which atmospheric $\Delta^{14} \mathrm{C}$ fits best with the $\Delta^{14} \mathrm{C}$ values obtained from radiocarbon analyses of the samples. Mean fine root age was calculated as the period between root formation and sample collection. This method overestimates fine root age by the time lag between $C$ fixation from the atmosphere and root construction (Gaudinski et al. 2001).

As a historic record of $\Delta^{14} \mathrm{C}$ in atmospheric $\mathrm{CO}_{2}$, we used summer measurements at Schauinsland, South Germany, for 1977-1996 (Levin and Kromer 1997) and 1997-2006 (Levin et al. 2008). In 2007, $\Delta^{14} \mathrm{C}$ at Schauinsland is assumed to be $51.5 \%$ (Levin, personal communication). 


\section{Statistical analysis}

Mass, $\mathrm{C}$ age and $\mathrm{C} / \mathrm{N}$ of fine roots from different soil depths were tested for normal distribution using the Shapiro-Wilk test. Means of the normally distributed data for $\mathrm{C}$ age were compared by one-factorial ANOVA followed by a Scheffé test. Data sets for fine root mass and $\mathrm{C} / \mathrm{N}$ ratio were skewed even after log or root transformation. Therefore, we used Kruskal-Wallis single factor analyses of variance, followed by non-parametric Mann-Whitney two-sample tests to detect differences in fine root mass and $\mathrm{C} / \mathrm{N}$ ratio with soil depths. Differences between biomass and necromass for each soil depth were analyzed using Mann-Whitney two-sample tests only. Root lifespan estimates were calculated using the Weibull function for right-censored data. These calculations were conducted using the software package SAS, version 9.1 (SAS Institute, Cary, USA). The dependence of root age on the $\mathrm{C} / \mathrm{N}$ ratio of roots was investigated by single-factor linear regression analyses with the software package Xact, version 8 (SciLab, Hamburg, Germany). Results of all tests are reported as significant if $\mathrm{P}<0.05$. 


\section{Results}

\section{Fine root inventory}

Soil coring showed that fine root biomass and necromass were highest in the organic layer and decreased substantially with soil depth (Figure 1). We calculated an average reduction in fine root biomass and necromass abundance per $10 \mathrm{~cm}$ increase in soil depth of 50 and $43 \%$, respectively. Adding up the values for the profile total, fine root necromass was higher than fine root biomass by $25 \%$. The total mass of living and dead fine roots up to $40 \mathrm{~cm}$ mineral soil depth was 439 and $550 \mathrm{~g} \mathrm{~m}^{-2}$, respectively.

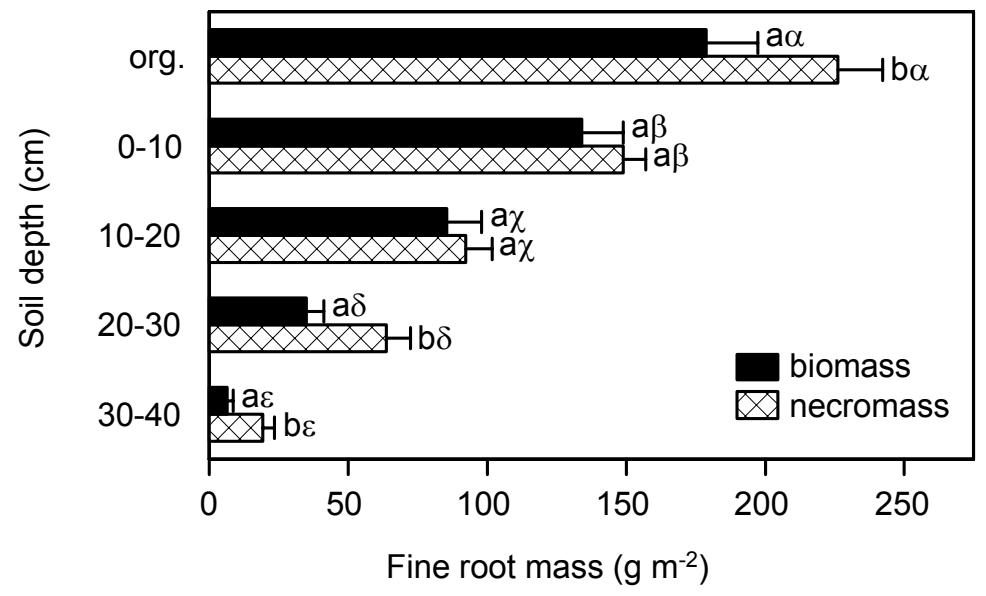

Figure 1: Vertical distribution of fine root biomass and necromass (mean $\pm \mathrm{SE}$ ) in the studied spruce forest. Different Latin letters indicate significant differences between biomass and necromass for a given soil depth, different Greek letters those between different soil depths for either root biomass or necromass.

\section{Seasonal fine root dynamics}

Fine root biomass and necromass in the organic layer as investigated by soil coring showed a distinct seasonal development (Figure 2A). At the first sampling date in December 2005, fine root biomass and necromass were similar with $182 \mathrm{~g} \mathrm{~m}^{-2}$ and 179 $\mathrm{g} \mathrm{m}^{-2}$. After a slight decrease until March 2006, fine root necromass increased by $115 \%$ to reach its highest value in June 2006. In contrast, fine root biomass remained stable during the same period. Between June and August 2006, fine root biomass and necromass decreased by 33 and $53 \%$, respectively. At the end of the study, root biomass was lower by $42 \mathrm{~g} \mathrm{~m}^{-2}$ than one year before while root necromass was higher by $53 \mathrm{~g} \mathrm{~m}^{-2}$ than in December 2005. Overall, seasonal dynamics were more pronounce in fine root necromass than in biomass. 

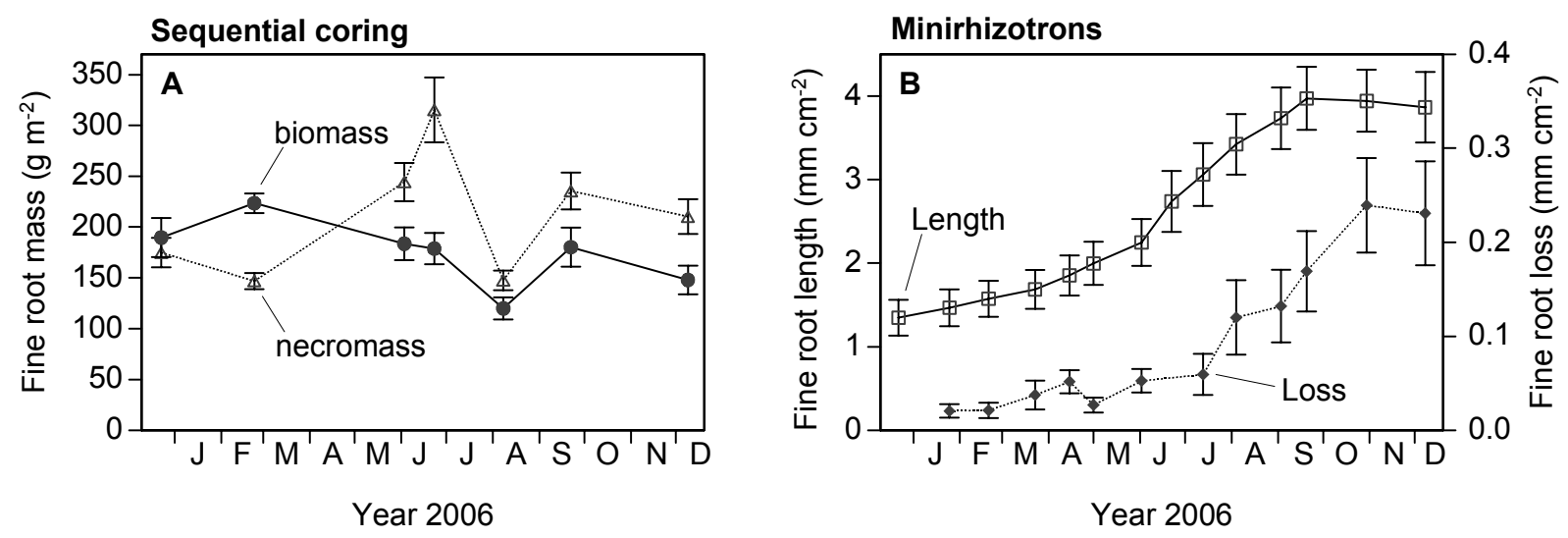

Figure 2: Seasonal fine root dynamics as investigated by sequential coring and minirhizotron observations in the organic layer of the study plots $(n=3)$ between December 2005 and December 2006. The results from sequential coring show fine root biomass and necromass (mean \pm SE) for 7 sampling dates (60 samples per date). Minirhizotron data of fine root length and loss (mean \pm SE) are illustrated for every month (24 tubes per date).

According to our minirhizotron data, fine root length and loss were not primarily controlled by seasonality. Instead, both increased almost continuously between December 2005 and September 2006 (Figure 2B). Only during the last three months of the study, root length and loss remained stable. As a result, fine root length was almost three times higher in December 2006 than one year before. This indicates that the fine root system in proximity to the minirhizotron tubes was not in a steady state during our study.

Variation in fine root $\Delta^{14} \mathrm{C}$ values and root age with size class and soil depth

The $\Delta^{14} \mathrm{C}$ signatures of fresh needles $(48.6 \%$ ) and fine roots $(51.1 \%$ ) collected in 2007 are in accordance with the estimated atmospheric $\Delta^{14} \mathrm{Co}_{2}$ value of $51.5 \%$ for the year 2007 (Figure 3). Hence, the radiocarbon concentration of fine roots was very close to that of the atmosphere during root construction.

All other live and dead fine root samples were heavier in terms of ${ }^{14} \mathrm{C}$ concentration compared to atmospheric $\mathrm{CO}_{2}$ of the year in which they were collected (Table 1). The $\Delta^{14} \mathrm{C}$ values of fine roots ranged between 68.6 and $133.6 \%$. They were lowest in the organic layer and increased with soil depth. As expected, the radiocarbon concentrations were higher in dead than in living roots. Furthermore, the radiocarbon concentration of fine roots increased with root diameter. In the organic layer, the $\Delta^{14} \mathrm{C}$ values of fine roots $<0.5 \mathrm{~mm}$ in diameter were on average $9 \%$ lower than those of roots between 0.5 and $1 \mathrm{~mm}$ in diameter, reflecting a difference in mean age of about 2 
years. However, fine roots $0.5-1 \mathrm{~mm}$ in diameter were slightly enriched in radiocarbon concentrations compared to those $>1 \mathrm{~mm}$. In 40-60 cm soil depth, the variation in $\triangle^{14} \mathrm{C}$ values between fine roots $<1 \mathrm{~mm}$ in diameter and fine roots $1-2 \mathrm{~mm}$ in diameter corresponds to a difference of 3 years.

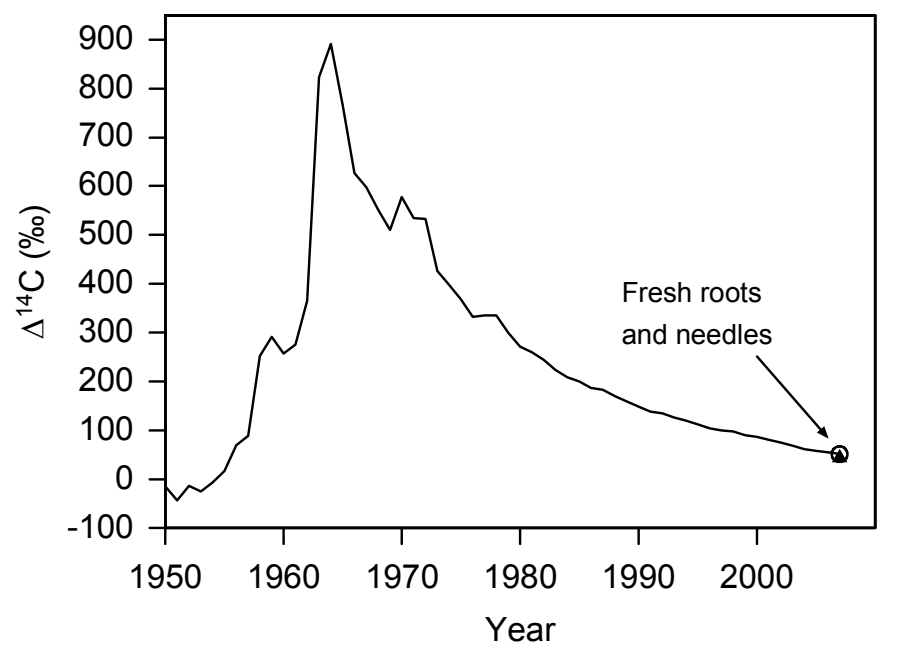

Figure 3: The development of $\Delta{ }^{14} \mathrm{CO}_{2}$ in the atmosphere and the mean $\Delta{ }^{14} \mathrm{C}$ values for samples of recently constructed fine roots (open circles; $\mathrm{n}=10$ ) and fresh needles (closed triangles; $\mathrm{n}=$ 10) collected in July 2007. The values for atmospheric $\Delta^{14} \mathrm{CO}_{2}$ are based on records in grapes grown in Russia from 1950 to 1976 (Burchuladze et al. 1989) and atmospheric measurements at Schauinsland, South Germany from 1977-1996 (Levin and Kromer 1997) and from 1997-2006 (Levin et al. 2008).

Table 1: $\Delta^{14} \mathrm{C}$ values (mean $\pm \mathrm{SE}$ ) for living and dead fine root samples of different diameter classes and soil depths.

\begin{tabular}{cccc}
\hline $\begin{array}{c}\text { Soil depth } \\
(\mathbf{c m})\end{array}$ & Status & $\begin{array}{c}\text { Root } \varnothing \\
(\mathbf{m m})\end{array}$ & $\begin{array}{c}\boldsymbol{\Delta}{ }^{14} \mathbf{C} \\
\mathbf{( \% o})\end{array}$ \\
\hline O horizon & living & $<2$ & $83.1 \pm 3.1^{*}$ \\
& dead & $<2$ & $94.2 \pm 2.9^{*}$ \\
& living & $<0.5$ & $68.6 \pm 3.1$ \\
& living & $0.5-1$ & $77.9 \pm 5.1$ \\
$0-10 \mathrm{~cm}$ & living & $1-2$ & $73.7 \pm 7.1$ \\
$10-20 \mathrm{~cm}$ & living & $<2$ & $87.0 \pm 4.4$ \\
$20-40 \mathrm{~cm}$ & living & $<2$ & $107.7 \pm 7.2$ \\
$40-60 \mathrm{~cm}$ & living & $<1$ & $110.8 \pm 6.0$ \\
& living & $1-2$ & $112.9 \pm 9.3$ \\
\end{tabular}

* Sample collection occurred in June 2006. All the other samples were collected in 2007. 
The estimated mean age of $C$ in living fine roots $<2 \mathrm{~mm}$ in diameter was 5 years in the organic layer and increased to 13 years in $40-60 \mathrm{~cm}$ mineral soil depth (Figure 4). While fine root ages increased substantially with depth in the upper soil (from 5 years in the organic layer to 11 years at $15 \mathrm{~cm}$ depth), differences in the lower soil were rather small (from 11 years at $15 \mathrm{~cm}$ depth to 13 years at $50 \mathrm{~cm}$ depth).

Fine root age (years)

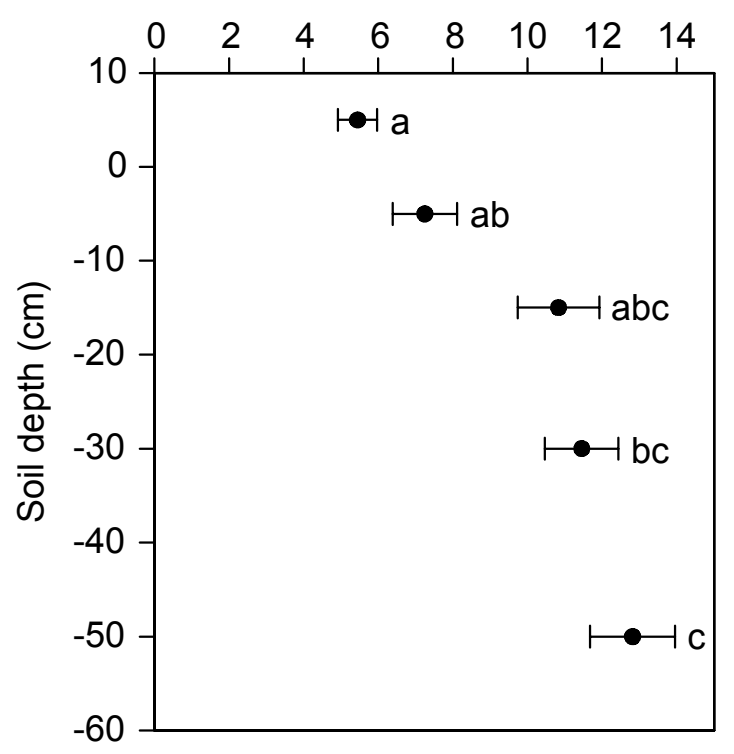

Figure 4: Estimated ages of fine root samples $($ mean $\pm \mathrm{SE})$ in the soil profile based on the results of accelerator mass spectrometry radiocarbon measurement. Atmospheric $\Delta^{14} \mathrm{C}$ values from Levin et al. (2008) were used as a proxy for estimating the fine root age of every sample. Different letters indicate significant differences between different soil depths.

Variation in fine root longevity with determination method and diameter class

We estimated the mean longevity for fine roots of three different size classes based on the radiocarbon, minirhizotron and sequential soil coring method in the organic layer. Root longevity estimates (in years) from radiocarbon data ranged from 4.0 to 5.4 and exceeded those from minirhizotron data (0.7-0.9) and sequential soil coring (0.9) by far (Table 2). Moreover, fine root longevity tended to increase with diameter: according to the radiocarbon and minirhizotron approach, fine roots $>0.5 \mathrm{~mm}$ in diameter were older than those $<0.5 \mathrm{~mm}$ in diameter by 33 and $29 \%$, respectively. 
Table 2: Longevity (mean $\pm \mathrm{SE}$ ) of fine roots from three different diameter classes in the organic layer as calculated from soil coring, minirhizotron and radiocarbon data.

\begin{tabular}{cccc}
\hline & \multicolumn{3}{c}{ Mean fine root longevity (years) } \\
Diameter & Radiocarbon & Minirhizotrons & Soil coring \\
$(\mathbf{m m})$ & & & \\
\hline$<0.5$ & $4.0 \pm 0.56$ & $0.7 \pm 0.06$ & \\
$0.5-2$ & $5.3 \pm 0.76$ & $0.9 \pm 0.14$ & \\
$<2$ & $5.4 \pm 0.53$ & $0.7 \pm 0.05$ & $0.9 \pm 0.04$ \\
\hline
\end{tabular}

\section{Vertical distribution of fine root $\mathrm{C} / \mathrm{N}$ ratio}

The mean $\mathrm{C} / \mathrm{N}$ ratio of living fine roots was lowest in the organic layer and increased continuously with soil depth (Figure 5). On average, root $\mathrm{C} / \mathrm{N}$ ratio increased at a rate of $10 \%$ per $10 \mathrm{~cm}$ increase in soil depth. However, the only significant difference in fine root $\mathrm{C} / \mathrm{N}$ ratio between two adjacent soil depths occurred for samples of the organic layer and those at $0-10 \mathrm{~cm}$ mineral soil depth. Variability in the $\mathrm{C} / \mathrm{N}$ ratio also increased substantially with depth. However, this was due to a decrease in the number of samples analyzed for $\mathrm{C}$ and $\mathrm{N}$ contents with soil depth reflecting the reduced fine root abundance in deeper soil layers.

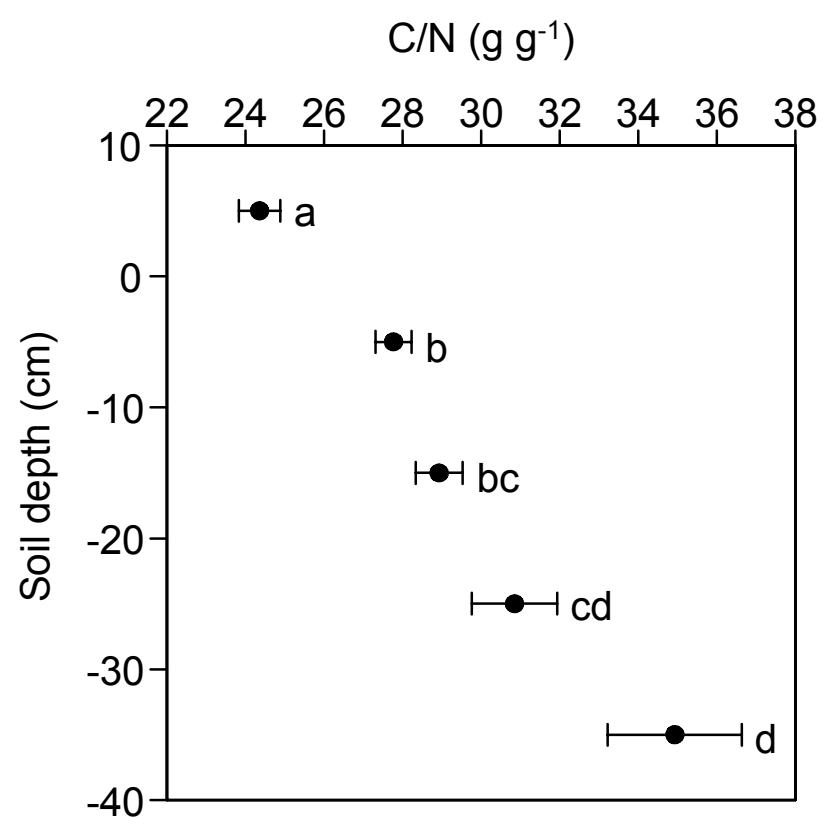

Figure 5: $\mathrm{C} / \mathrm{N}$ ratio of fine root samples (mean $\pm \mathrm{SE}$ ) collected in five different soil depths (organic layer, $\mathrm{n}=62 ; 0-10 \mathrm{~cm}, \mathrm{n}=106 ; 10-20 \mathrm{~cm}, \mathrm{n}=86 ; 20-30 \mathrm{~cm}, \mathrm{n}=38,30-40 \mathrm{~cm}, \mathrm{n}=8$ ). Different letters indicate significant differences in root $\mathrm{C} / \mathrm{N}$ ratio between different soil depths. 
Variation in fine root longevity with $\mathrm{C} / \mathrm{N}$ ratio

Because $C$ ages and $C / N$ ratios of fine roots $<2 \mathrm{~mm}$ increased with depth at similar rates, both parameters were found to be positively correlated $\left(r^{2}=0.93\right.$; Figure 6). However, the correlation was only marginally significant $(p=0.07)$ because our results were based on mean values at four soil depths.

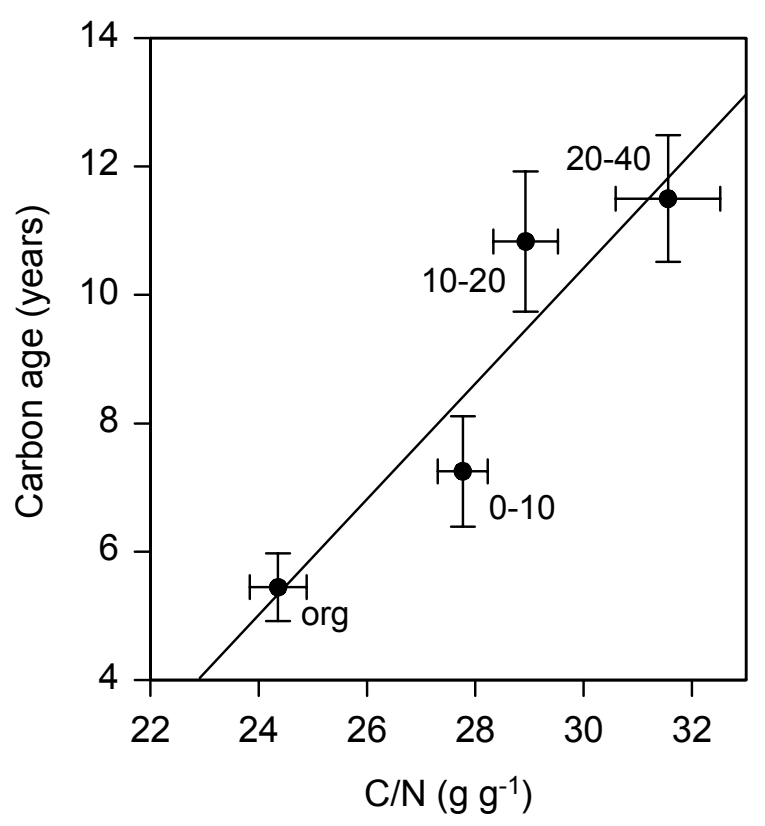

Figure 6: Relationship between $\mathrm{C}$ age (mean $\pm \mathrm{SE}$ ) and $\mathrm{C} / \mathrm{N}$ ratio (mean $\pm \mathrm{SE}$ ) of fine roots for four soil depths (organic layer, $0-10 \mathrm{~cm}, 10-20 \mathrm{~cm}, 20-40 \mathrm{~cm}$ ). Regression equation: $\mathrm{y}=-16.6+$ $0.9 \mathrm{x}\left(\mathrm{r}^{2}=0.93 ; \mathrm{p}<0.7\right)$. 


\section{Discussion}

\section{Fine root biomass and necromass distribution}

Fine root biomass up to $40 \mathrm{~cm}$ mineral soil depth was $439 \mathrm{~g} \mathrm{~m}^{-2}$ in our study. This result falls in the middle range of values reported from 25 other stands of Norway spruce in temperate forests (69-640 $\mathrm{g} \mathrm{m}^{-2}$; Leuschner and Hertel 2003). Fine root biomass density was highest in the organic layer and decreased significantly with soil depth. This vertical distribution of fine root biomass is likely to reflect the availability of nutrients in the Fichtelgebirge stand. Borken et al. (2007) and Schmid and Kazda (2002) found similar vertical distribution patterns for fine root biomass of mature Norway spruce on comparable sites in Germany and Austria. Fine root necromass exceeded fine root biomass by $25 \%$ in the studied spruce stand. This outcome differs from the results of a literature review by Jackson et al. (1997) who found that fine root biomass was higher than fine root necromass in 10 temperate coniferous forests. We propose that our detailed sorting method, including even the smallest rootlets, led to much higher fine root necromass values than obtained by conventional analyses.

\section{Dependence of root longevity on root diameter and soil depth}

Longevity of fine roots was clearly influenced by root diameter in the present study. Based on our results from the minirhizotron and radiocarbon approach, fine roots $>0.5$ $\mathrm{mm}$ in diameter of the organic layer lived, on average, longer than those $<0.5 \mathrm{~mm}$ in diameter by 29 and $35 \%$, respectively. Similarly, the $C$ age of roots between 1 and 2 $\mathrm{mm}$ in diameter was $22 \%$ higher than that of roots $<1 \mathrm{~mm}$ in diameter at $40-60 \mathrm{~cm}$ mineral soil depth. Our findings are in accordance with the results of several other studies using minirhizotrons (Wells and Eissenstat 2001; Baddeley and Watson 2005) and isotopic analyses (Gaudinski et al. 2001; Matamala et al. 2003; Joslin et al. 2006). Of particular interest for assessing the relationship between size and longevity of fine roots is the work of Wells and Eissenstaat (2001), which shows that overwinter survivorship varied markedly among apple roots differing in diameter by only a few tenths of millimetres.

The reasons for enhanced fine root longevity with increasing root diameter remain largely uncertain. The smallest diameter roots typically contain the highest concentrations of N (Pregitzer et al. 1997; Pregitzer et al. 2002). As a consequence, these tissues are more efficient in nutrient uptake but also more susceptible to herbivory and root parasitism than thicker fine roots (Graham 1995). In addition, smaller diameter 
roots were shown to be more vulnerable to abiotic stressors such as soil drought (Espeleta et al. 1999). It is also rational that high-order roots live longer than low-order roots because the death of a high-order root entails the loss of all the adjacent lowerorder roots. Since fine root diameters increase with root order (Pregitzer 1997), we indirectly investigated the influence of branching order on fine root longevity in our study. Revealing the exact relationship between root diameter and longevity was not possible by dividing fine roots in two size classes only. However, our findings clearly showed that the root system in the studied spruce stand consists of at least two fine root populations turning over at very different time intervals.

Fine root longevity as estimated by radiocarbon analyses increased continuously with depth. Fine roots in 40-60 cm mineral soil lived longest with 13 years, those in the organic layer shortest with 5 years. Several other authors found a similar trend for increasing fine root longevity with soil depth in minirhizotron (Wells et al. 2002; Baddeley and Watson 2005) and radiocarbon studies (Gaudinski et al. 2001; Joslin et al. 2006). Pregitzer et al. (1993) created patches of moist soil in a temperate hardwood forest by adding continuously water through plastic tubes to the soil. They observed that fine roots lived significantly longer in permanently humid soil patches than outside. Gaul et al. (2008) found that soil frost decreased fine root longevity in the organic layer of the studied spruce stand. In our study, fine roots in deeper layers are expected to experience less fluctuations in soil moisture and soil temperature than those in shallow soil. Fine root longevity was also shown to be negatively correlated to $\mathrm{N}$ availability (Majdi and Andersson 2005; Majdi and Kangas 1997) and the number of neighbouring roots as possible competitors (Wells and Eissenstat 2001). In agreement, $\mathrm{N}$ availability and fine root density decreased with soil depth in the studied spruce stand. By relating root longevity to root biomass for every soil depth interval, we calculated an average lifetime of 7.6 years for all fine roots in the studied spruce stand.

\section{Longevity estimates as dependent on method}

The method of investigation caused by far the strongest influence on estimated fine root longevity. Sequential coring and minirhizotron observations produced rather similar results for fine root longevity in the organic layer of the studied spruce stand of less than 1 year in both cases. In contrast, fine roots in the upper soil as investigated by radiocarbon analyses lived on average more than 5 years, exceeding the values obtained from sequential coring and minirhizotrons by factors of 6 and 8 , respectively. Our results on fine root longevity from the minirhizotron and radiocarbon approaches 
are in accordance with recent studies using either one or both of these methods (Gaudinki et al. 2001; Tierney and Fahey 2002; Joslin et al. 2006; Withington et al. 2006; Majdi et al. 2007).

Minirhizotron observations and isotope-based estimates of $\mathrm{C}$ age are currently considered as being the most promising approaches for investigating fine root longevity (Tierney and Fahey 2002; Guo et al. 2008). However, it remains largely uncertain, why both methods produce very different results. In that context, it was proposed that isotopic approaches might underestimate fine root longevity if new roots were built with old C from senescing tissues or storage pools (Luo et al. 2003; Strand et al. 2008). In our study, we showed that this was not the case, because fresh fine roots clearly reflected the radiocarbon signature of the year, in which they were sampled. When Gaudinski et al. (2001) introduced the radiocarbon approach to estimate fine root age, they suggested that discrepancies between their results and longevity estimates based on minirhizotron observations could have been caused by the fact that different pools of fine roots were investigated. In that context, they assumed that picking roots from the soil for radiocarbon analyses was likely to miss many small, fast-cycling rootlets, while observations through minirhizotrons might have under-represented the thicker and less dynamic fine roots. As a consequence, radiocarbon data usually overestimate actual fine root longevity, whereas minirhizotron observations may lead to underestimations.

This suggestion was confirmed by two recent studies (Guo et al. 2008; Strand et al. 2008). Strand et al. (2008) found that underestimations of fine root longevity were particularly relevant in short-duration minirhizotron studies. They showed that fine roots lived on average by almost $50 \%$ longer in minirhizotron studies conducted over 3 years compared to those restricted to a period of up to 1 year. Based on their findings, they assumed that fine root longevity was decreased in short duration studies because the root systems had not reached equilibria after tube installation. In our study, the fine root system surrounding the minirhizotron tubes was also not in equilibrium, which could partly explain the discrepancy between the root longevity estimates from minirhizotron observations and radiocarbon analyses. Furthermore, we cannot rule out that ephemeral fine roots were somewhat under-represented in our radiocarbon analyses although we paid attention to include even the smallest rootlets. However, these two factors alone are rather unlikely to explain the huge discrepancy between fine root longevity estimates from both methods. Other reasons like different calculation approaches for minirhizotron and radiocarbon based estimates may also influence the results for fine root longevity (Guo et al. 2008; Strand et al. 2008). Sequential coring is often considered to produce less realistic results on fine root dynamics than direct 
observations through minirhizotrons (Majdi 1996; Hendricks et al. 2006; Majdi et al. 2007). This approach is criticized as an indirect method that requires assumptions about root growth and mortality, which are difficult to prove (Majdi 2007). In that context, the minimum-maximum method to calculate fine root production from sequential coring data presumes an annual pulse of fine root production and that root growth and mortality occur in temporally isolated phases. In our study, fine root longevity estimates from soil coring were similar to those based on minirhizotron observations. Fine root biomass and necromass showed a clear seasonal development in the studied spruce stand, making soil coring in combination with the minimum-maximum method to a valuable option for estimating root longevity at this site.

\section{Longevity and $\mathrm{C} / \mathrm{N}$ ratio}

In the studied spruce stand, the $\mathrm{C} / \mathrm{N}$ ratio of fine root biomass increased with soil depth. The observed differences in root $\mathrm{C} / \mathrm{N}$ ratio were caused by decreasing root $\mathrm{N}$ concentrations with depth, while the $\mathrm{C}$ concentrations remained stable across the soil profile (data not shown). Borken et al. (2007) also found that root $\mathrm{N}$ concentrations were lowest in the deepest soil layers of four Norway spruce stands in Southern Germany. They argue that root $\mathrm{N}$ concentrations normally reflect the availability of $\mathrm{N}$ in the soil, which decreases with depth. In accordance, $\mathrm{N}$ availability was highest in the organic layer and decreased continuously with soil depth in the Fichtelgebirge stand (Hentschel et al. 2007).

Radiocarbon age and $\mathrm{C} / \mathrm{N}$ ratio of living fine roots increased with depth at similar rates indicating a positive correlation between both factors in the studied spruce forest. Similarly, Withington et al. (2006) discovered that fine root life span and root $\mathrm{C} / \mathrm{N}$ ratio were significantly correlated in a study on trees of 11 temperate species. They proposed that fine roots with relatively high $\mathrm{N}$ concentrations lived shorter because they were more susceptible to herbivory.

\section{Conclusion}

Fine root longevity in the studied spruce stand is expected to range between 0.7 and 7.6 years. We explain this large variation with the heterogeneity of the fine root system and suggest that the results from minirhizotron observations reflect the turnover rates of fast-cycling roots, while those from radiocarbon analyses mirror the rates of long-lived 
roots. In the absence of data on aboveground production, we were not able to quantify the proportional allocation of $\mathrm{C}$ to the fine root system. However, the estimation of Jackson et al. (1997), that fine roots comprise about one third of NPP, may be realistic for the studied spruce stand only, if average root longevity is very similar to the results obtained from minirhizotrons and soil coring, and not to the radiocarbon data.

\section{Acknowledgements}

This research was funded by the Deutsche Forschungsgemeinschaft (DFG) in the framework of the Research Group 562 "Soil processes under extreme meteorological conditions". We thank Irmgard Gerstmann for supporting us during the fine root analyses. Egbert Matzner and Werner Borken coordinated the research group. Gerhard Müller, Uwe Hell and Andreas Kolb from Bayreuth Center of Ecology and Environmental Research (BayCEER) provided technical assistance during installation and operation of the research plots. Radiocarbon analyses were conducted at the AMS facility of MaxPlanck-Institute for Biogeochemistry, Jena (Germany); this technical support is gratefully acknowledged. 


\section{References}

Aber J D, Melillo J M, Nadelhoffer K J, McClaugherty C A and Pastor J 1985 Fine root turnover in forest ecosystems in relation to quantity and form of nitrogen availability: a comparison of two methods. Oecologia 66, 317-321.

Aerts R, Bakker C and de Caluwe $\mathrm{H} 1992$ Root turnover as determinant of the cycling of $\mathrm{C}, \mathrm{N}$, and $\mathrm{P}$ in a dry heathland ecosystem. Biogeochemistry $15,175-190$.

Baddeley J A and Watson C A 2005 Influences of root diameter, tree age, soil depth and season on fine root survivorship in Prunus avium. Plant and Soil 276, 15-22.

Bauhus J and Bartsch N 1996 Fine-root growth in beech (Fagus sylvatica) forest gaps. Can J For Res 26, 2153-2159.

Borken W, Kossmann G and Matzner E 2007 Biomass, morphology and nutrient contents of fine roots in four Norway spruce stands. Plant Soil 292, 79-93.

Comas L H, Eissenstat D L and Lakso A N 2000 Assessing root death and root system dynamics in a study of grape canopy pruning. New Phytol 147, 171-178.

Edwards N T and Harris W F 1977 Carbon cycling in a mixed deciduous forest floor. Ecol. 58, 431-437.

Espeleta J F, Eissenstat D M and Graham J H 1999 Citrus root responses to localized drying soil: a new approach to studying mycorrhizal effects on the roots of mature trees. Plant Soil 206, 1-10.

Foken T 2003 Lufthygienisch-Bioklimatische Kennzeichnung des oberen Egertales. Bayreuther Forum Ökologie 100, 1-118.

Gaudinski J B, Trumbore S E, Davidson E A, Cook A C, Markewitz D and Richter D D 2001 The age of fine-root carbon in three forests of the eastern United States measured by radiocarbon. Oecologia 129, 420-429.

Gaul D, Hertel D and Leuschner Ch 2008 Effects of experimental soil frost on the fine root system of mature Norway spruce. J. Plant Nutr. Soil Sci. 5.

Gill R A and Jackson R B 2000 Global patterns of root turnover for terrestrial ecosystems. New Phytol 147, 13-31.

Graefe S, Hertel D and Leuschner Ch 2008 Estimating fine root turnover in tropical forests along an elevational transect using minirhizotrons. Biotropica, DOI 10.1111/j.1744-7429.2008.00419.x.

Graham J H 1995 Root regeneration and tolerance of citrus rootstocks to root rot caused by Phytophthora nicotianae. Phytopathology 85, 111-117.

Guo D, Li H, Mitchell R J, Han W, Hendricks J J, Fahey T J and Hendrick R L 2008 Fine root heterogeneity by branch order: exploring the discrepancy in root turnover estimates between minirhizotron and carbon isotopic methods. New Phytol 172, 523-535. 
Hendricks J J, Hendrick R L, Wilson C A, Mitchell R J, Pecot S D and Guo D L 2006 Assessing the patterns and controls of fine root dynamics: an empirical test and methodological review. Journal of Ecology 94, 40-57.

Hentschel K, Borken W and Matzner E 2007 Leaching losses of inorganic N and DOC following repeated drying and rewetting of a spruce forest soil. Plant Soil 300, 21-34.

Hertel D 1999 The fine root system of mixed stands of European beech: structure, dynamics and interspecific competition. (In German). Cramer, Berlin. pp. 190.

Hertel D and Leuschner Ch 2002 A comparison of four different fine root production estimates with ecosystem carbon balance data in a Fagus-Quercus mixed forest. Plant Soil 239, 237-251.

Jackson R B, Mooney H A and Schulze E D 1997 A global budget for fine root biomass, surface area, and nutrient contents. Proceedings of the National Academy of Sciences of the United States of America 94, 7362-7366.

Joslin J D and Wolfe M H 1999 Disturbances during minirhizotron installation can affect root observation data. Soil Sci Soc Am J 63, 218-221.

Joslin J D, Gaudinski J B, Torn M S, Riley W J and Hanson P J 2006 Fine-root turnover patterns and their relationship to root diameter and soil depth in a 14C-labeled hardwood forest. New Phytol 172, 523-535.

Kurz W A and Kimmins J P 1987 Analysis of some sources of error in methods used to determine fine root production in forest ecosystems: A simulation approach. Can J For Res 17, 909-912.

Leuschner C, Backes K, Hertel D, Schipka F, Schmitt U, Terborg O and Runge M 2001 Drought responses at leaf, stem and fine root levels of competitive Fagus sylvatica L. and Quercus petraea (Matt.) Liebl. trees in dry and wet years. For Ecol Manage 149, 33-46.

Leuschner C and Hertel D 2003 Fine root biomass of temperate forests in relation to soil acidity and fertility, climate, age and species. Progress in Botany 64, 405-438.

Levin I, Hammer S, Kromer B and Meinhardt F 2008 Radiocarbon observations in atmospheric CO2: Determining fossil fuel $\mathrm{CO} 2$ over Europe using Jungfraujoch observations as background. Sci Total Environ 391, 211-216.

Levin I and Kromer B 1997 Twenty years of atmospheric 14CO2 observations at Schauinsland station, Germany. Radiocarbon 39, 205-218.

Luo Y Q 2003 Uncertainties in interpretation of isotope signals for estimation of fine root longevity: theoretical considerations. Global Change Biology 9, 1118-1129.

Majdi H 1996 Root sampling methods - Applications and limitations of the minirhizotron technique. Plant Soil 185, 255-258.

Majdi H and Kangas P 1997 Demography of fine roots in response to nutrient applications in a Norway spruce stand in southwestern Sweden. Ecoscience 4, 199205. 
Majdi $\mathrm{H}$ and Andersson P 2005 Fine root production and turnover in a Norway spruce stand in northern Sweden: Effects of nitrogen and water manipulation. Ecosystems 8, 191-199.

Majdi H, Pregitzer K S, Moren A S, Nylund J E and Agren G I 2005 Measuring fine root turnover in forest ecosystems. Plant Soil 276, 1-8.

Majdi H, Nylund JE and Agren G I 2007 Root respiration data and minirhizotron observations conflict with root turnover estimates from sequential soil coring. Scand $J$ Forest Res 22, 299-303.

Matamala R, Gonzalez-Meler M A, Jastrow J D, Norby R J and Schlesinger W H 2003 Impacts of fine root turnover on forest NPP and soil $\mathrm{C}$ sequestration potential. Science $302,1385-1387$.

McClaugherty C A, Aber J D and Melillo J M 1982 The role of fine roots in the organicmatter and nitrogen budgets of 2 forested ecosystems. Ecol. 63, 1481-1490.

Persson H 1978 Root dynamics in a young Scots pine stand in Central Sweden. Oikos $30,508-519$.

Pregitzer K S, Hendrick R L and Fogel R 1993 The demography of fine roots in response to patches of water and nitrogen. New Phytol 125, 575-580.

Pregitzer K S, Kubiske M E, Yu C K and Hendrick R L 1997 Relationships among roof branch order, carbon, and nitrogen in four temperate species. Oecologia 111, 302-308.

Pregitzer K S, Laskowski M J, Burton A J, Lessard V C and Zak D R 1998 Variation in sugar maple root respiration with root diameter and soil depth. Tree Physiology 18, 665670.

Pregitzer K S, DeForest J L, Burton A J, Allen M F, Ruess R W and Hendrick R L 2002 Fine root architecture of nine North American trees. Ecological Monographs 72, 293309.

Pritchard S G and Strand A E 2008 Can you believe what you see? Reconciling minirhizotron and isotopic estimates of fine root longevity. New Phytol 177, 287-291.

Publicover D A and Vogt K A 1993 A comparison of methods for estimating forest fineroot production with respect to sources of error. Can J For Res 23, 1179-1186.

Schlesinger W H 1997 Biogeochemistry. An analysis of global change, 2nd edition. Academic Press, San Diego.

Schmid I and Kazda M 2002 Root distribution of Norway spruce in monospecific and mixed stands on different soils. For Ecol Manage 159, 37-47.

Singh J S, Lauenroth W K, Hunt H W and Swift D M 1984 Bias and random errors in estimators of net root production: a simulation approach. Ecol. 65, 1760-1764.

Strand A E, Pritchard S G, McCormack M L, Davis M A and Oren R 2008 Irreconcilable differences: fine-root life spans and soil carbon persistence. Science 319, 456-458. 
Tierney G L and Fahey T J 2002 Fine root turnover in a northern hardwood forest: a direct comparison of the radiocarbon and minirhizotron methods. Can J For Res 32, 1692-1697.

Tingey D T, Phillips D L and Johnson M G 2000 Elevated CO2 and conifer roots: effects on growth, life span and turnover. New Phytol 147, 87-103.

Trumbore S, Da Costa E S, Nepstad D C, De Camargo P B, Martinelli L I Z A, Ray D, Restom T and Silver W 2006 Dynamics of fine root carbon in Amazonian tropical ecosystems and the contribution of roots to soil respiration. Global Change Biology 12, 217-229.

Vogt K A, Vogt D J and Bloomfield J 1998 Analysis of some direct and indirect methods for estimating root biomass and production of forests at an ecosystem level. Plant Soil 200, 71-89.

Wells C E and Eissenstat D M 2001 Marked differences in survivorship among apple roots of different diameters. Ecol. 82, 882-892.

Wells C E, Glenn D M and Eissenstat D M 2002 Changes in the risk of fine-root mortality with age: A case study in peach, Prunus persica (Rosaceae). Am. J. Bot. 89, 79-87.

Withington J M, Elkin A D, Bulaj B, Olesinski J, Tracy J N, Bouma T J, Oleksyn J, Anderson L J, Modrzynski J, Reich P B and Eissenstat D M 2003 The impact of material used for minirhizotron tubes for root research. New Phytol. 160, 533-544.

Withington J M, Reich P B, Oleksyn J and Eissenstat D M 2006 Comparisons of structure and life span in roots and leaves among temperate trees. Ecological Monographs 76, 381-397. 
Chapter 5

Synthesis 


\section{Background of the study}

Quantifying the effects of expected climate change on fine root dynamics and rootderived carbon fluxes has been elusive until now. There is not only a lack of knowledge on the responses of fine roots to changing climatic conditions; even under natural conditions, growth and turnover of fine roots are difficult to assess due to methodological restrictions. Fine roots have been considered as highly dynamic, thereby representing one of the most important components of carbon cycling in forest ecosystems. Jackson et al. (1997) calculated that more than one third of terrestrial carbon would be used for the production and maintenance of fine roots if mean root longevity was one year. Accordingly, fine root turnover times between 5 months and 2 years are mainly reported from root studies using common techniques like sequential soil coring and observations through minirhizotrons (Gill and Jackson 2000).

More recently, however, a new method to estimate fine root longevity based on radiocarbon was introduced (Gaudinski et al. 2001). While a range from 5 months to 2 years for root longevity as obtained from traditional methods seemed to be already quite wide, the results from radiocarbon studies indicated that fine roots may well live for more than one decade. The discrepancy between longevity estimates increased the uncertainty about the importance of fine roots as carbon sinks and aroused an intensive debate on the efficacy of different methods (Strand et al. 2008). Although this debate is far from being resolved and reliable carbon budgets for fine root systems remain unavailable, the prospect of climate change urgently requires information on possible responses of fine roots to abiotic stressors such as drought and frost.

The present study had the objective to investigate the effects of simulated climate change on the fine root system of mature Norway spruce. In addition, fine root longevity was estimated using three independent methods with the aim to move forward in the establishment of reliable carbon budgets for forest ecosystems. The hypotheses of this study were that (i) soil drought and soil frost increase fine root mortality, thereby leading to a higher input of root-derived organic matter to the soil pool and that (ii) drought and frost induced fine root mortality is compensated by higher rates of fine root production. 


\section{Effects of climate change on fine root dynamics and belowground carbon fluxes}

The fine root density in the spruce forest was highest in the organic layer and decreased with soil depth at rates typical for late-successional forest tree species (Gale and Grigal 1987). Fine root biomass in the studied stand was shown to be characteristic for that of mature Norway spruce forests at montane elevation with poor nutrient availability.

The results from sequential soil coring showed that mild soil drought increased fine root mortality in the organic layer of the studied stand. This finding was in accordance with most other studies investigating the effects of reduced soil moisture on fine root dynamics (e.g. Mainiero and Kazda 2006; Meier and Leuschner 2008). Enhanced fine root production in the organic layer of the spruce stand during drought and after rewetting compensated for the root losses due to water shortage. According to Eissenstat et al. (2000), roots are only maintained under drought if the benefit : cost ratio in terms of water uptake and carbon expenditure is higher than under conditions of root shedding and construction of new roots. This was apparently not the case in the present study. Compensation root growth due to soil drought was also observed by other authors. (e.g. Santantonio and Herrmann 1985). In other studies, however, root production was shown to stay constant or even decrease as a consequence of water shortage (e.g. Meier and Leuschner 2008). Vertical displacement of fine roots as often reported after drought (Persson et al. 1995) could not be proven for this study. In general, comparing existing studies about the effects of soil drought on fine roots is not conclusive because the outcomes differ a lot depending on tree species, climate, soil conditions and the method of investigation. In the present study, there was also a discrepancy between results obtained from sequential soil coring and those from minirhizotron observations. This discrepancy was most likely caused by the fact that the root system in proximity to the minirhizotron tubes had not reached equilibrium until more than one year after tube installation. Hence, the minirhizotron results were considered as less realistic because they might have reflected compensation growth, rather than fine root dynamics in the studied spruce stand (Joslin and Wolfe 1999). Based on the results from sequential coring, it was calculated that experimental soil drought led to an additional input of $26 \mathrm{~g} \mathrm{~m}^{-2}$ of carbon and $1.0 \mathrm{~g} \mathrm{~m}^{-2}$ of nitrogen to the particulate organic matter fraction of the organic layer. By contrast, the general impact of soil drought on fine root dynamics in the mineral soil seemed to be negligible.

The effects of soil frost on fine root production and mortality were similar to those observed for soil drought. Sequential coring revealed that the frost treatment increased 
fine root mortality by almost $30 \%$. Even at temperatures below $-5{ }^{\circ} \mathrm{C}$, enhanced fine root production compensated for the root loss. This was a surprising result, since fine root growth is expected to cease when temperatures approach the freezing point. Experimental soil frost was estimated to cause an excess flux of about $20 \mathrm{~g} \mathrm{~m}^{-2}$ of carbon and $0.7 \mathrm{~g} \mathrm{~m}^{-2}$ of nitrogen to the organic layer. In total, frost influenced fine root dynamics and root-derived carbon fluxes even more than drought because its effects were not restricted to the organic layer but also recognizable in the upper $25 \mathrm{~cm}$ of the mineral soil. Again, comparing the results of this study to those of other studies is not easy. While there exists a lot of controversial information about the responses of drought on roots, the effects of frost on root systems have hardly been investigated. Up to now, Tierney et al. (2001) conducted the only comparable study in a mature forest. They removed snow to enhance soil frost and their results on fine root mortality and root-derived nitrogen fluxes were similar to those of the present study.

The results of the experiments in the spruce stand confirmed our hypotheses that (i) soil drought and frost increase fine root mortality leading to a higher input of root-derived organic matter to the soil pool and that (ii) drought and frost enhanced fine root production to compensate for the losses. The outcome of the present study about drought and frost effects on fine root systems might be particularly relevant because results from similar experimental approaches conducted in mature forests are hardly available. Most other research investigating the responses of fine roots to abiotic stressors is either conducted under artificial conditions in laboratories, thereby focussing on seedlings, or consists of gradient studies (e.g. Hansen et al. 1996; Bigras and Dumais 2005). Applying the results of studies on seedlings under artificial conditions to assess the impacts of drought and frost on mature forests at the ecosystem-level is a highly delicate task (Joslin et al. 2000). Similarly, genetic and other site differences may lead to confusion about the interpretation of results from gradient studies.

\section{Estimating fine root longevity}

A lack of knowledge regarding fine root dynamics strongly limits the accuracy of forest carbon budgets. In this study, variability of fine root longevity with root diameter, root $\mathrm{C} / \mathrm{N}$ ratio and soil depth was investigated using radiocarbon analyses. In addition, sequential soil coring and minirhizotron observations were applied to compare root longevity estimates obtained from different methods. 
As expected, thicker fine roots lived on average longer than thinner ones in the studied spruce stand. Based on our results from the minirhizotron and radiocarbon approach, fine roots of the organic layer between 0.5 and $2 \mathrm{~mm}$ in diameter lived longer than those $<0.5 \mathrm{~mm}$ in diameter by 29 and $35 \%$, respectively. Several other authors also found a positive correlation between root diameter and longevity (e.g. Wells and Eisenstat 2001; Joslin et al. 2006). Smaller diameter roots were shown to be more vulnerable to herbivory and abiotic stressors such as soil drought (Graham 1995; Espeleta et al. 1999). More recently, it has been suggested that root order might be an even more appropriate determinant for root longevity than diameter (e.g. Joslin et al 2006). Indeed, analysing the longevity of fine roots according to their position on the branch system seems to be a promising alternative. However, because this approach is extremely labour-intensive, it was not a feasible alternative for the present study.

Radiocarbon analyses showed that fine root longevity increased even stronger with soil depth than with root diameter. In the organic layer, fine roots lived on average for 5 years, which was about 8 years shorter than in $40-60 \mathrm{~cm}$ mineral soil. Fine roots in deeper layers are expected to experience less fluctuations in soil moisture and soil temperature than those in surface-near horizons. In addition, root herbivory and parasitism are most relevant in the upper soil (Graham 1995). Similar to fine root longevity, root $\mathrm{C} / \mathrm{N}$ ratio also increased with soil depth. It is expected that carbon and nitrogen concentrations in root tissue reflect the availability of both elements in the soil profile (Borken et al. 2007). In agreement, nitrogen availability was highest in the organic layer and decreased with soil depth in the present study.

The method of investigation influenced fine root longevity more than any other factor. While the results from sequential coring and minirhizotron observations were quite similar (< 1 year), radiocarbon analyses produced much higher longevity estimates $(>5$ years). The results on fine root longevity from the minirhizotron and radiocarbon approaches are in accordance with the findings of recent studies using either one or both of these methods (e.g. Tierney and Fahey 2002; Joslin et al. 2006). It is remarkable that the application of the two methods lead to extremely different results because both, minirhizotron observations and radiocarbon analyses are suggested to provide the most reliable estimates on fine root turnover and longevity (Majdi et al. 2005). An important disadvantage of the present minirhizotron study is the fact that the fine root system surrounding the tubes was not in a steady state. However, this reason alone is very unlikely to explain the huge discrepancy between longevity estimates for both methods. Instead, it is increasingly suggested that the two approaches focus on dissimilar root populations and use different calculation procedures, thereby producing 
very different outcomes. Actual root longevity in the studied spruce forest ranges most likely between the results obtained from minirhizotron observations and radiocarbon analyses.

\section{Concluding remarks}

The outcome of this thesis clearly showed that different fractions of the fine root system cycle carbon at very different rates. However, the study could not fully explain the huge discrepancies between longevity estimates obtained from different methods. I suggest that former estimates on the importance of fine roots for terrestrial carbon cycling may be realistic only, if average root longevity is very similar to the results obtained from minirhizotron observations and sequential soil coring. By contrast, the contribution of fine root growth and turnover to net primary production would be much less than previously expected if root longevity was closely reflected by the results from radiocarbon analyses.

The present study indicated that future climate change may have a considerable impact on fine root dynamics in forest ecosystems. Increasing frequencies of drought and frost were shown to increase fine root mortality and root-derived carbon fluxes in the studied spruce stand. However, in the absence of data on aboveground biomass, my results do not allow for the drawing of conclusions about the effects of drought and frost on the carbon budget of the studied forest. In that context, enhanced fine root turnover may have drawn on the carbohydrate reserves of the spruce trees, thereby possibly reducing aboveground productivity. Since the fine root system in the studied stand was typical for that of mature Norway spruce forests at montane elevation with poor nutrient availability, the validity of the results from the present study is most likely restricted to very similar stands. In other forest ecosystems, the potential of fine roots for carbon sequestration under mild drought and frost remains uncertain. In order to increase the reliability of predictions on forest carbon budgets under changing climatic conditions, future studies should focus on a wide variety of ecosystems and investigate both, below- and aboveground responses of trees to abiotic stressors of different intensities. 


\section{References}

Bigras, F.J., Dumais, D. 2005. Root-freezing damage in the containerized nursery: impact on plantation sites - A review. New Forests 30, 167-184.

Borken, W., Kossmann, G., Matzner, E. 2007. Biomass, morphology and nutrient contents of fine roots in four Norway spruce stands. Plant and Soil 292, 79-93.

Eissenstat, D.M., Wells, C.E., Yanai, R.R., Whitbeck, J.L. 2000. Building roots in a changing environment: implications for root longevity. New Phytologist 147, 33-42.

Espeleta, J.F., Eissenstat, D.M., Graham, J.H. 1999. Citrus root responses to localized drying soil: a new approach to studying mycorrhizal effects on the roots of mature trees. Plant and Soil 206, 1-10.

Gale, M.R., Grigal, D.F. 1987. Vertical root distributions of northern tree species in relation to successional status. Canadian Journal of Forest Research 17, 829-834.

Gaudinski, J.B., Trumbore, S.E., Davidson, E.A., Cook, A.C., Markewitz, D., Richter, D.D. 2001. The age of fine-root carbon in three forests of the eastern United States measured by radiocarbon. Oecologia 129, 420-429.

Gill, R.A., Jackson, R.B. 2000. Global patterns of root turnover for terrestrial ecosystems. New Phytologist 147, 13-31.

Graham, J.H. 1995. Root regeneration and tolerance of citrus rootstocks to root rot caused by Phytophthora nicotianae. Phytopathology 85, 111-117.

Hansen, J., Vogg, G., Beck, E. 1996. Assimilation, allocation and utilization of carbon by 3-year-old Scots pine (Pinus sylvestris L.) trees during winter and early spring. Trees 11, 83-90.

Jackson, R.B., Mooney, H.A., Schulze, E.D. 1997. A global budget for fine root biomass, surface area, and nutrient contents. Proceedings of the National Academy of Sciences, USA 94, 7362-7366.

Joslin, J.D., Wolfe, M.H. 1999. Disturbances during minirhizotron installation can affect root observation data. Soil Science Society of America Journal 63, 218-221.

Joslin, J.D., Wolfe, M.H., Hanson, P.J. 2000. Effects of altered water regimes on forest root systems. New Phytologist 147, 117-129.

Joslin, J.D., Gaudinski, J.B., Torn, M.S., Riley, W.J., Hanson, P.J. 2006. Fine-root turnover patterns and their relationship to root diameter and soil depth in a 14C-labeled hardwood forest. New Phytologist 172, 523-535.

Mainiero, R., Kazda, M. 2006. Depth-related fine root dynamics of Fagus sylvatica during exceptional drought. Forest Ecology and Management 237, 135-142.

Majdi, H., Pregitzer, K.S., Moren, A. S., Nylund, J.E., Agren, G.I. 2005 Measuring fine root turnover in forest ecosystems. Plant and Soil 276, 1-8.

Meier, I.C., Leuschner, Ch. 2008. Genotypic variation and phenotypic plasticity in the drought response of fine roots of European beech. Tree Physiology 28, 297-309. 
Persson, H., von Fircks, Y., Majdi, H., Nilsson, L.O. 1995. Root distribution in a Norway spruce (Picea abies (L.) Karst.) stand subjected to drought and ammonium-sulphate application. Plant and Soil 168/169, 161-165.

Santantonio, D., Hermann, R.K. 1985. Standing crop, production, and turnover of fine roots on dry, moderate, and wet sites of mature Douglas fir in Western Oregon. Annales des Sciences Forestieres 42, 113-142.

Strand, A.E., Pritchard, S.G., McCormack, M.L., Davis, M.A., Oren, R. 2008. Irreconcilable differences: fine-root life spans and soil carbon persistence. Science 319, 456-458.

Tierney, G.L., Fahey, T.J., Groffman, P.M., Fitzhugh, R.D., Driscoll, C.T. 2001. Soil freezing alters fine root dynamics in a northern hardwood forest. Biogeochemistry 56, 175-190.

Tierney, G.L., Fahey, T.J. 2002. Fine root turnover in a northern hardwood forest: a direct comparison of the radiocarbon and minirhizotron methods. Canadian Journal of Forest Research 32, 1692-1697.

Wells, C.E., Eissenstat, D.M. 2001. Marked differences in survivorship among apple roots of different diameters. Ecology 82, 882-892. 


\section{ACKNOWLEDGEMENTS}

Many people supported me during the development of my PhD thesis. Without some of them, the composition of this thesis would not have been feasible; without others, the daily work would have been much less pleasant and cheerful.

First of all, I would like to thank Prof. Christoph Leuschner for giving me the opportunity to conduct research on an interesting topic. Dr. Dietrich Hertel was a highly reliable and patient supervisor teaching me a lot about (root) ecology.

A special thanks goes to Irmgard Gerstmann, who supported me with the toughest of all works - root sorting. Mechthild Stange, Heinz Coners, Dirk Deilke and Ulrich Werder helped me on several occasions with the field work and technical problems. Equally important for the outcome of this thesis was the installation and operation of the research plots, which was assured by the staff of the Bayreuth Center of Ecology and Environmental Research. My colleagues from the Plant Ecology group provided a pleasant and stimulating working atmosphere. In that context I would like to thank especially Boris and my roommates Marieke and Cathi for their company during the last three years.

My work was not only funded by the German Research Foundation (DFG), but at least partly also by my parents - thank you very much.

The support of my wife was invaluable; Marcela, without your help during field and laboratory work as well as your understanding for my labour-intensive occupation during the last three years, it would not have been possible to finish my thesis as soon. Finally, I am very grateful to my son Emilio for having cheered me up during the last six months with a lot of fantastic smiles. 


\section{CURRICULUM VITAE}

\section{Personal details}

Date of birth

July 1,1977

Place of birth

Mainz, Germany

Nationality

German

Education

$2005-2008$

PhD study in Biodiversity and Ecology at Georg-August University of Göttingen, Germany.

$2004-2005$

Study of Biology at the University of Umeå, Sweden.

Degree obtained: M. Sc.

$1999-2003$

Study of International Forest Ecosystem Management at Eberswalde University of Applied Sciences, Germany.

Degree obtained: B. Sc.

$1995-1997$

Gutenberg Gymnasium Mainz, Germany.

High Schol graduation: Abitur 